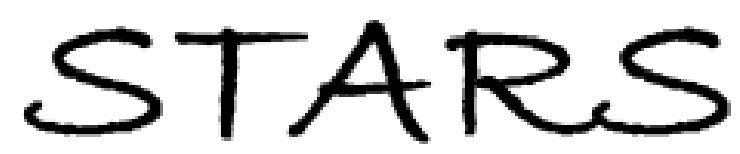

University of Central Florida

STARS

\title{
The Effect Of Free Chlorine And Chloramines On Lead Release In A Distribution System
}

Ferdinand Vasquez

University of Central Florida

Part of the Environmental Engineering Commons

Find similar works at: https://stars.library.ucf.edu/etd

University of Central Florida Libraries http://library.ucf.edu

This Masters Thesis (Open Access) is brought to you for free and open access by STARS. It has been accepted for inclusion in Electronic Theses and Dissertations, 2004-2019 by an authorized administrator of STARS. For more information, please contact STARS@ucf.edu.

\section{STARS Citation}

Vasquez, Ferdinand, "The Effect Of Free Chlorine And Chloramines On Lead Release In A Distribution System" (2005). Electronic Theses and Dissertations, 2004-2019. 411.

https://stars.library.ucf.edu/etd/411

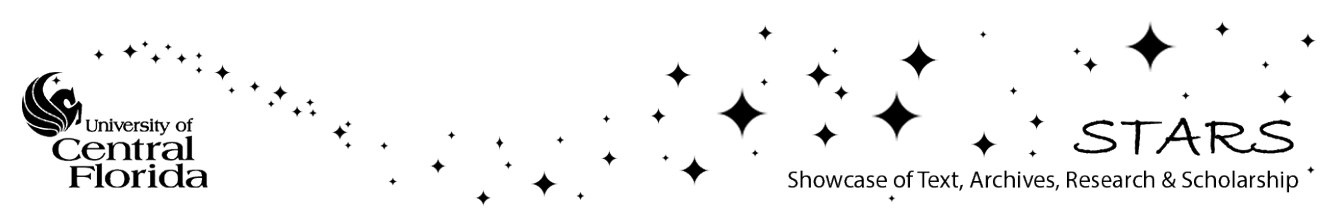




\title{
THE EFFECT OF FREE CHLORINE AND CHLORAMINES ON LEAD RELEASE IN A DISTRIBUTION SYSTEM
}

\author{
by \\ FERDINAND ALFREDO VASQUEZ \\ B.S. University of Central Florida, 2002
}

A thesis submitted in partial fulfillment of the requirements for the degree of Master of Science in Environmental Engineering in the Department of Civil and Environmental Engineering in the College of Engineering and Computer Sciences at the University of Central Florida

Orlando, Florida

Spring Term

2005 
C 2005 Ferdinand Vasquez 


\begin{abstract}
Total lead release in drinking water in the presence of free chlorine and chloramine residuals was investigated in field, laboratory and fundamental investigations for finished waters produced from ground (GW), surface (SW), saline (RO) and blended (B) sources. Field investigations found more total lead was released in the presence of chloramines than in the presence of free chlorine for RO and blended finished waters; however, there were no statistical differences in total lead release to finished GW and SW. Laboratory measurements of finished waters oxidation-reduction potential (ORP) were equivalent by source and were not affected by the addition of more than $100 \mathrm{mg} / \mathrm{L}$ of sulfates or chlorides, but were significantly higher in the presence of free chlorine relative to chloramines. Development of Pourbaix diagrams revealed the $\mathrm{PbO}_{2}$ was the controlling solid phase at the higher ORP in the presence of free chlorine and $\mathrm{Pb}_{3}\left(\mathrm{CO}_{3}\right)_{2}(\mathrm{OH})_{2(\mathrm{~s})}$ (hydrocerussite) was the controlling solid phase in the presence of chloramines at the lower ORP, which mechanistically accounted for the observed release of total lead as $\mathrm{PbO}_{2}$ is much less soluble than hydrocerussite. The lack of differences in total lead release to finished $\mathrm{GW}$ and $\mathrm{SW}$ was attributed to differences in water quality and intermittent behavior of particulate release from controlling solid films.
\end{abstract}




\section{ACKNOWLEDGMENTS}

Above all, I honor God for his abundant love and mercy given to me unconditionally and for the continuous guidance and strength that inspired me to complete my aspiration.

I am exceptionally appreciative to Dr. James S. Taylor, my advisor and committee chairman, who was fundamental in my advancement, professionally and personally, and was supportive throughout my studies. I am grateful for my committee members, Dr. J. S. Taylor, Dr. John D. Dietz and Dr. Andrew A. Randall, for their service, cooperation, and advisement. Special regards are extended to the faculty of the Civil and Environmental Engineering Department at UCF for their professionalism and to the student colleagues at UCF for their kind friendship.

I give special thanks to my family for their love and support. You gave me constant encouragement and taught me to live with integrity. 


\section{TABLE OF CONTENTS}

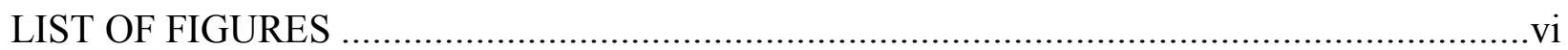

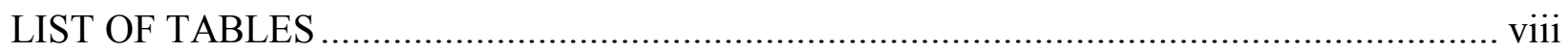

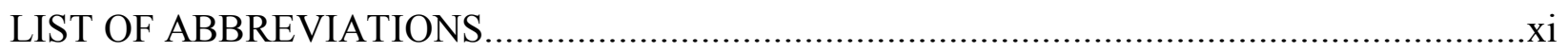

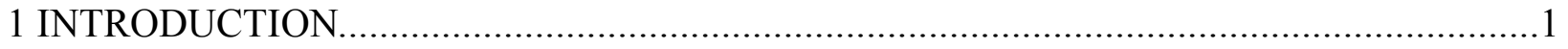

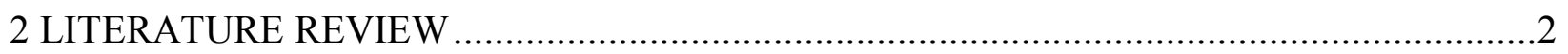

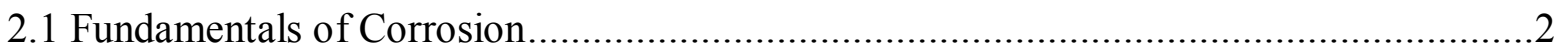

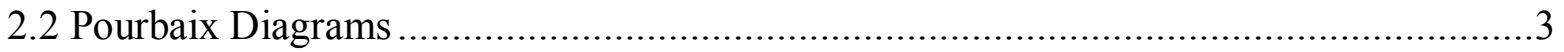

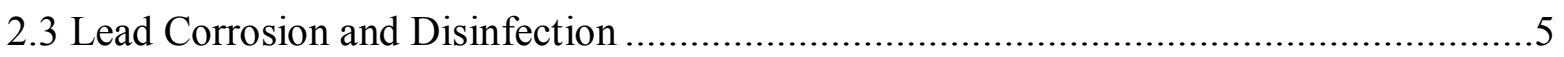

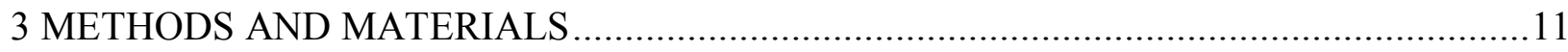

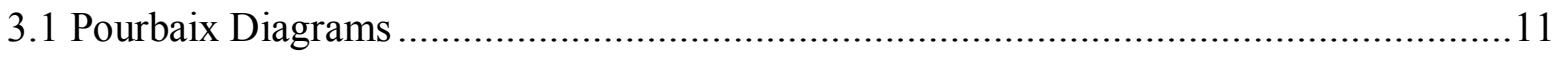

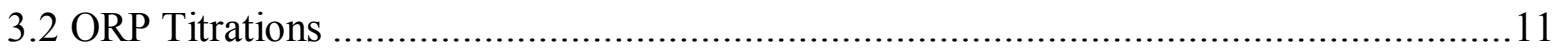

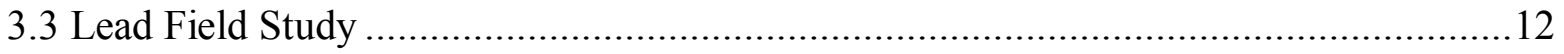

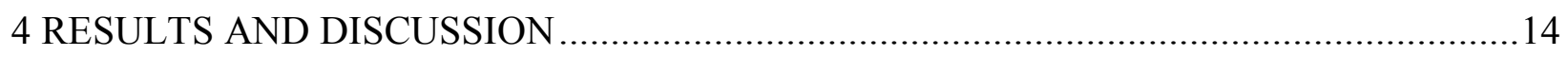

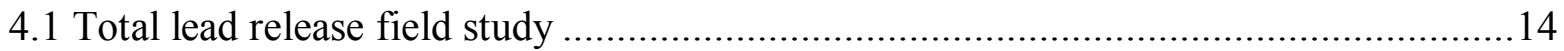

4.2 Effect of $\mathrm{Cl}_{2}$ and $\mathrm{NH}_{2} \mathrm{Cl}$ on Drinking Water Potential..........................................20

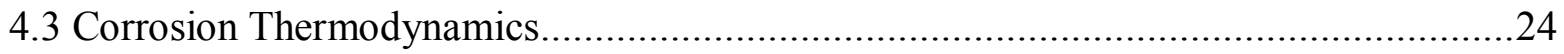

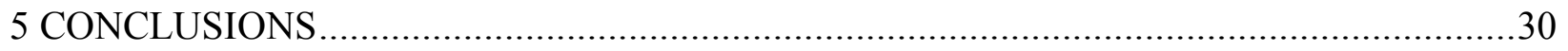

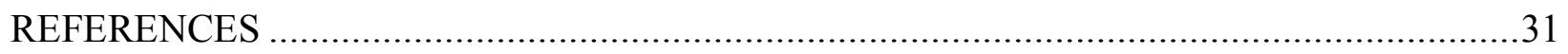

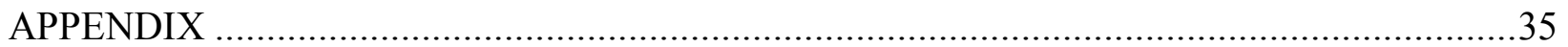




\section{LIST OF FIGURES}

Figure 2.1 Electrochemical potential comparison of free chlorine and chloramines in water at 25

${ }^{\circ} \mathrm{C}$. Free chlorine concentration $=10^{-4} \mathrm{M}$, Chloramines concentration $=10^{-4} \mathrm{M}$ and

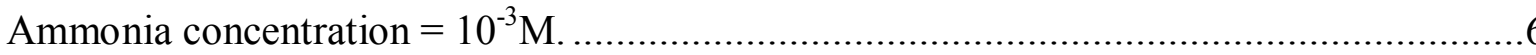

Figure 3.1 Influent treated water to pilot distribution system ......................................... 12

Figure 3.2 Copper coil tubing with lead coupons in corrosion shed ....................................12

Figure 4.1 Average lead release by source and disinfectant ..............................................15

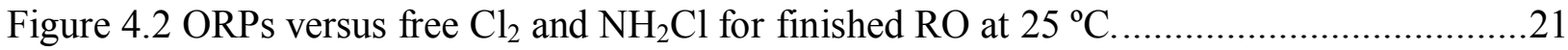

Figure 4.3 ORPs versus free $\mathrm{Cl}_{2}$ and $\mathrm{NH}_{2} \mathrm{Cl}$ for finished $\mathrm{SW}$ at different temperatures............22

Figure 4.4 Effect of increasing sulfate addition on finished surface water ORP for varying free

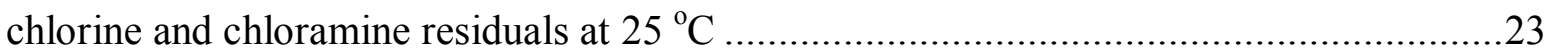

Figure 4.5 Effect of increasing chloride addition on finished RO water ORP for varying free chlorine and chloramine residuals at $25{ }^{\circ} \mathrm{C}$.

Figure 4.6 Lead potential versus $\mathrm{pH}$ and $\mathrm{pC}_{\mathrm{pb}}$ showing average total lead release and predominant lead species for groundwater and blended water quality conditions in field studies for free chlorine and chloramines. Alkalinity $=200 \mathrm{mg} / \mathrm{L} \mathrm{CaCO}_{3}$.

Figure 4.7 Lead potential versus $\mathrm{pH}$ and $\mathrm{pC}_{\mathrm{pb}}$ showing average total lead release and predominant lead species for desalinated water and surface water quality in field studies for free chlorine and chloramines. Alkalinity $=50 \mathrm{mg} / \mathrm{L} \mathrm{CaCO}_{3}$. .27 
Figure 4.8 Log soluble lead species versus alkalinity and $\mathrm{pH}$ assuming cerussite and hydrocerussite controlling solid phases and actual data in the presence of free chlorine and chloramines and from Schock (1999) ..................................................................29 


\section{LIST OF TABLES}

Table 3.1 Water quality parameters and methods................................................... 13

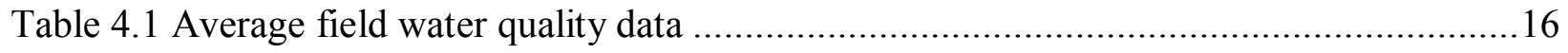

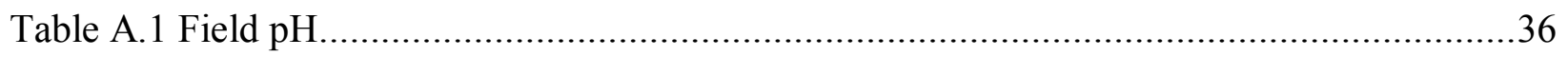

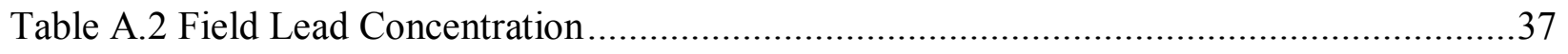

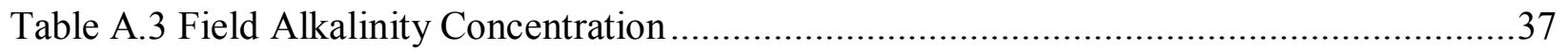

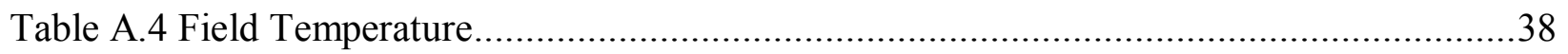

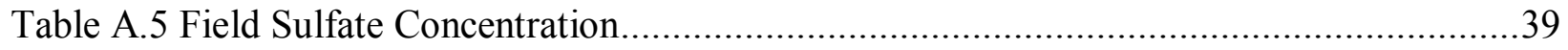

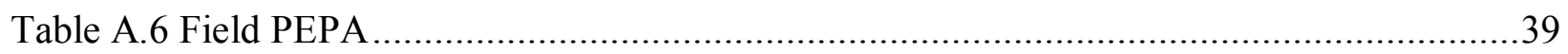

Table A.7 Field Chloride Concentration ...........................................................................40

Table A.8 Field Chlorine Residual Concentration......................................................40

Table A.9 Field NOx-N Concentration ................................................................ 41

Table A.10 Field Ammonia Concentration ....................................................................41

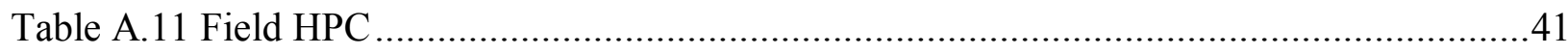

Table A. 12 ORP Titration of GW at 5C using Free Chlorine ….......................................42

Table A.13 ORP Titration of GW at 10C using Free Chlorine ............................................43

Table A.14 ORP Titration of GW at 25C using Free Chlorine .........................................45

Table A.15 ORP Titration of GW at 30C using Free Chlorine .......................................46

Table A.16 ORP Titration of GW at 5C using Chloramine ..........................................48

Table A.17 ORP Titration of GW at 10C using Chloramine .............................................49 
Table A.18 ORP Titration of GW at 25C using Chloramine ...............................................50

Table A.19 ORP Titration of GW at 30C using Chloramine ….............................................51

Table A.20 ORP Titration of SW at 5C using Free Chlorine...............................................52

Table A.21 ORP Titration of SW at 15C using Free Chlorine ……........................................54

Table A.22 ORP Titration of SW at 25C using Free Chlorine.................................................56

Table A.23 ORP Titration of SW at 30C using Free Chlorine ................................................57

Table A.24 ORP Titration of SW at 5C using Chloramine ...................................................59

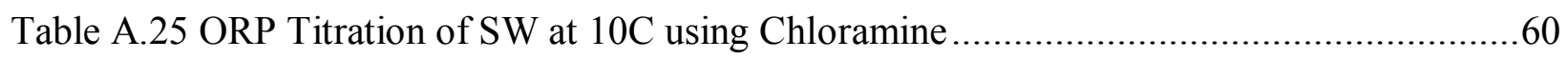

Table A.26 ORP Titration of SW at 25C using Chloramine ..................................................61

Table A.27 ORP Titration of SW at 30C using Chloramine ..................................................62

Table A.28 ORP Titration of SW at $25 \mathrm{C}$ using Free Chlorine with $50 \mathrm{mg} / \mathrm{L} \mathrm{SO}_{4}{ }^{-2} \ldots \ldots \ldots \ldots \ldots \ldots \ldots . . .63$

Table A.29 ORP Titration of SW at 25C using Free Chlorine with $100 \mathrm{mg} / \mathrm{L} \mathrm{SO}_{4}{ }^{-2}$..................64

Table A.30 ORP Titration of SW at $25 \mathrm{C}$ using Free Chlorine with $150 \mathrm{mg} / \mathrm{L} \mathrm{SO}_{4}{ }^{-2} \ldots \ldots \ldots \ldots \ldots \ldots . . .65$

Table A.31 ORP Titration of SW at 25C using Chloramine with $50 \mathrm{mg} / \mathrm{L} \mathrm{SO}_{4}{ }^{-2} \ldots \ldots \ldots \ldots \ldots \ldots \ldots \ldots . . .67$

Table A.32 ORP Titration of SW at 25C using Chloramine with $100 \mathrm{mg} / \mathrm{L} \mathrm{SO}_{4}{ }^{-2}$....................68

Table A.33 ORP Titration of SW at 25C using Chloramine with $150 \mathrm{mg} / \mathrm{L} \mathrm{SO}_{4}{ }^{-2}$.....................69

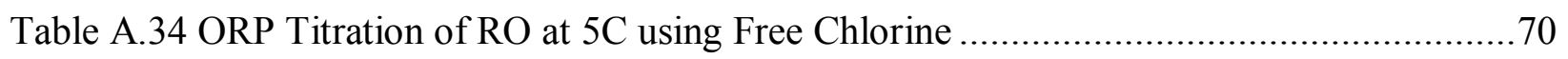

Table A. 35 ORP Titration of RO at 15C using Free Chlorine ...............................................

Table A.36 ORP Titration of RO at 25C using Free Chlorine .................................................73

Table A.37 ORP Titration of RO at 30C using Free Chlorine ……….....................................74

Table A.38 ORP Titration of RO at 5C using Chloramine ……..............................................76

Table A.39 ORP Titration of RO at 10C using Chloramine ……..........................................77

Table A.40 ORP Titration of RO at 25C using Chloramine ……..........................................78 
Table A.41 ORP Titration of RO at 30C using Chloramine

Table A.42 ORP Titration of RO at 25C using Free Chlorine with $35.5 \mathrm{mg} / \mathrm{L} \mathrm{Cl}^{-} \ldots \ldots \ldots \ldots \ldots \ldots \ldots . . . .80$

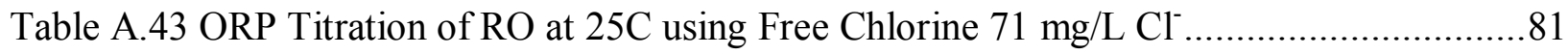

Table A.44 ORP Titration of $\mathrm{RO}$ at $25 \mathrm{C}$ using Free Chlorine $106.5 \mathrm{mg} / \mathrm{L} \mathrm{Cl}^{-} \ldots \ldots \ldots \ldots \ldots \ldots \ldots \ldots \ldots . . . . . . \ldots 2$

Table A.45 ORP Titration of RO at $25 \mathrm{C}$ using Chloramine $35.5 \mathrm{mg} / \mathrm{L} \mathrm{Cl}^{-} \ldots \ldots \ldots \ldots \ldots \ldots \ldots \ldots \ldots \ldots . . .83$

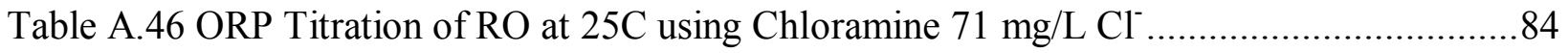

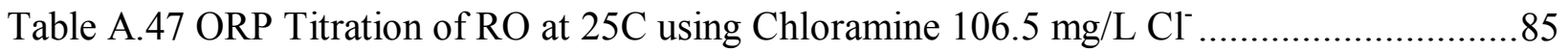




\section{LIST OF ABBREVIATIONS}

$\begin{array}{ll}\text { DPB } & \text { Disinfection by-product } \\ \text { redox } & \text { oxidation-reduction } \\ E & \text { potential } \\ E^{o} & \text { Standard potential } \\ \text { pH } & \text { Potential hydrogen } \\ \text { pC } & \text { negative log of the molar concentration } \\ { }^{\circ} \text { C } & \text { degrees Celsius } \\ \text { AL } & \text { Action level } \\ \text { WASA } & \text { Water and Sewer Authority } \\ \text { ORP } & \text { oxidation-reduction potential } \\ \text { GW } & \text { ground water } \\ \text { SW } & \text { surface water } \\ \text { RO } & \text { desalinated water } \\ \text { B } & \text { blended water } \\ \text { TBW } & \text { Tampa Bay Water } \\ \text { HPC } & \text { Heterotrophic plate count } \\ \text { PEPA } & \text { Potential of Exoproteolytic Activity } \\ \text { SM } & \text { Standard Methods } \\ \text { cfu } & \text { Coliform forming units } \\ \text { PDS } & \text { Pilot distribution system } \\ \text { HRT } & \text { Hydraulic retention time } \\ \text { DIPb } & \text { Dissolved lead } \\ \text { XPS } & \text { X-Ray Photoelectron spectroscopy } \\ & \end{array}$




\section{INTRODUCTION}

The adverse health effects of human lead consumption have been and are presently an international concern (Fewtrell et al., 2004; Vinceti et al., 2001; Bellinger et al., 1991; and USEPA, 2004). Particulate and dissolved lead are known drinking water contaminants that primarily come from the release of lead in lead pipes, solders and plumbing fixtures in distribution and home plumbing systems (Lee et al, 1989; Gardels et al, 1989; and Leroy, 1993). Lead release in drinking water is not simplistic, and can be related to chemical oxidation, possibly biological oxidation and physical mechanisms (turbulence) of lead and lead solid phases (Schock, 1999; 1990; \& 1989; and Leroy, 1993).

Chlorinated disinfection by-products (DBPs), like lead, are regulated in drinking water and can adversely affect human health. Many utilities have chosen to use chloramines for residual maintenance in drinking water distribution systems in order to comply with DBP regulations (Haas, 1999 and USEPA, 1998). However, concerns for lead release have recently increased due to recent reports of higher lead concentrations in a distribution system following the change from free chlorine to chloramines for residual maintenance (Cohn, 2004). This article presents a comparison of the thermodynamic potential of free chlorine and chloramines and theoretical controlling solid phases as measured in the laboratory and the lead release from field studies in the presence of free chorine and chloramines for finished waters produced from ground, surface and saline sources. 


\section{LITERATURE REVIEW}

Corrosion of metal pipes in drinking water distribution systems is a common problem in the water community. Corrosion can be described as a fundamental oxidation-reduction (redox) reaction and has been extensively studied by several researchers (Lytle et al., $2000 \& 1993$;

Schock, 1990; 1989; 1983; 1981 \& 1980; Boffardi, 1995; and Hem at al., 1973). Specific references to fundamental corrosion, thermodynamics and disinfection by-products (DBPs) are reported in this abbreviated literature review.

\section{$\underline{2.1}$ Fundamentals of Corrosion}

All corrosion reactions require an electron donor, an electron acceptor, an electrical connection and return. A redox reaction demonstrating lead pipe corrosion by dissolved oxygen is shown in Equation 2.1.

$$
\begin{aligned}
& 2 \mathrm{~Pb}_{(s)} \leftrightarrow 2 \mathrm{~Pb}^{2+}+4 e^{-} \\
& \mathrm{O}_{2(a q)}+4 \mathrm{H}^{+}+4 e^{-} \leftrightarrow 2 \mathrm{H}_{2} \mathrm{O}
\end{aligned}
$$

$$
2 \mathrm{~Pb}_{(s)}+\mathrm{O}_{2(a q)}+4 \mathrm{H}^{+} \leftrightarrow 2 \mathrm{~Pb}^{2+}+2 \mathrm{H}_{2} \mathrm{O}
$$

\section{Equation 2.1 Redox reaction of lead and water}

Corrosion, as shown in Equation 2.1, occurs because all components of an electrochemical cell are present. Lead (the anode) transfers electrons to dissolved oxygen, which 
is reduced to water (the cathode). Ions move between the cathode and anode because of an external connection, which could be water, and are returned through reactions with water or other chemical species. The standard potential $\left(E^{o}\right)$ value for the half reaction is determined by Gibb's free energy, as shown in Equation 2.2.

$\Delta G^{o}=n F E^{o}$

\section{Equation 2.2 Gibb's free energy and potential}

where: $\Delta G^{o}=$ Gibb's free energy, kcal

$n=$ number of electrons involved in the half reaction, equivalent

$F=$ Faraday's constant, $23.06 \mathrm{kcal} /($ volt-equivalent)

$E^{o}=$ standard potential, volt

The standard potential, $E^{o}$, of the corrosion reaction in an actual solution is determined by the Nernst equation as shown in Equation 2.3, which determines the driving force and direction (oxidation, reduction or equilibrium) of the reaction (Snoeyink et al., 1980).

$$
E=E^{\circ}-\frac{2.3 R T}{n F} \log \left(\frac{r e d}{o x}\right)
$$

\section{Equation 2.3 Nernst equation}

where: $E=$ potential, volt

$E^{o}=$ standard potential, volt

$R=$ ideal gas constant, $0.001987 \mathrm{Kcal} /($ deg-mole)

$T=$ degrees Kelvin, ${ }^{\circ} \mathrm{K}$

$n=$ number of electrons involved in the half reaction, equivalent

$F=$ Faraday's constant, $23.06 \mathrm{kcal} /($ volt-equivalent)

red $=$ reduced species in a reaction written as a reduction reaction

$o x=$ oxidized species in a reaction written as a reduction reaction

\subsection{Pourbaix Diagrams}

The Nernst equation can be used to graphically represent controlling species during corrosion. An E-pH diagram, or Pourbaix diagram, portrays dominant soluble and insoluble species as a function of $E, \mathrm{pH}$ and other water quality parameters. Other species exist at these 
conditions, but the Pourbaix diagram portrays the dominant species. Three dimensional Pourbaix diagrams are useful in that the effect of varying concentration can be shown as the negative $\log$ of the molar concentration of the oxidized species or $\mathrm{pC}$. Pourbaix diagrams distinguish among dominant species and indicate corrosion, immunity, and passivation for given water quality conditions. Typically, solid films that are attributed to passivation could become an impervious barrier between the corroding metal and water, and "short-circuit" the corrosion reaction. Elimination of the electrical connection would stop corrosion. However, many solid films are not impervious and provide excellent conditions for continuing corrosion. Natural waters are complex; and if only stable and predominate species are considered, the dominant corrosion reactions can be observed (Stumm et al., 1981).

Pourbaix (1966) published Pourbaix diagrams for lead considering $\mathrm{Pb}_{(\mathrm{s})}, \mathrm{Pb}^{2+}, \mathrm{PbO}_{(\mathrm{s})}$, $\mathrm{PbO}_{2(\mathrm{~s})}, \mathrm{Pb}_{3} \mathrm{O}_{4(\mathrm{~s})}, \mathrm{PbH}_{2(\mathrm{~g})}, \mathrm{HPbO}_{2}^{-}$and $\mathrm{PbCO}_{3(\mathrm{~s})}$ species that combined solid oxides and carbonates at equilibrium. These diagrams demonstrated inclusion of $\mathrm{PbCO}_{3(\mathrm{~s})}$ (cerussite) extended the region of passivation into the stability region of water between $\mathrm{pH} 6$ and 12 . Cerussite formation increased passivation because of the extension of cerussite into the previous predominant, relatively soluble $\mathrm{PbO}_{(\mathrm{s})}$, which reduced lead corrosion.

$\mathrm{Pb}_{3}\left(\mathrm{CO}_{3}\right)_{2}(\mathrm{OH})_{2(\mathrm{~s})}$ or hydrocerussite was incorporated into another Pourbaix diagram as an additional solid carbonate phase in 1985 (AWWARF). Similar results were shown in that immunity and passivation occurred when $\mathrm{Pb}_{(\mathrm{s})}$ and $\mathrm{PbO}_{2(\mathrm{~s})}$ were dominate; however, basic lead carbonate, $\mathrm{Pb}_{3}\left(\mathrm{CO}_{3}\right)_{2}(\mathrm{OH})_{2(\mathrm{~s})}$ or hydrocerussite, displaced cerussite and passivated lead.

Varying carbonate concentrations affects lead species predominance (Schock, 1999). Schock demonstrated varying carbonate concentration dramatically changed hydrocerussite passivation from a large area at $\mathrm{pH} 8.5$ to 11 for $2.4 \mathrm{mg} \mathrm{C} / \mathrm{L}$ to a thin sliver near $\mathrm{pH} 11$ for $24 \mathrm{mg}$ 
$\mathrm{C} / \mathrm{L}$ in the stability region of water, and demonstrated that increasing carbonate alkalinity was not always beneficial for reducing lead corrosion. More recently, Schock's development and interpretation of lead release using thermodynamics was recognized as excellent because it clearly showed the increased potential of drinking water due to a free chlorine residual relative to a chloramine residual changed dominance of lead species from $\mathrm{Pb}^{+2}$ from a hydrocerussite controlling solid phase to the less soluble $\mathrm{Pb}^{+4}$ from a $\mathrm{PbO}_{2}$ controlling solid phase. This provided a fundamental reason why total lead concentrations increased in the Washington D. C. drinking water following a conversion from free chlorine to chloramine residual maintenance (Renner, 2004).

\section{$\underline{2.3} \underline{\text { Lead Corrosion and Disinfection }}$}

Chlorine and chloramines species are widely used for residual maintenance and the control of pathogenic microorganisms in drinking water distribution systems. Although both are used for disinfection, free chlorine $\left(\mathrm{HOCl}\right.$ and $\left.\mathrm{OCl}^{-}\right)$is a stronger oxidant and disinfectant than monochloramine $\left(\mathrm{NH}_{2} \mathrm{Cl}\right)$, which is the primary form of chloramine residual in distribution systems (Singer et al., 1999). Either is predicted to chemically oxidize lead at equilibrium, which theoretically increases released lead in drinking water (Boffardi, 1988).

The difference in electrochemical potential between free chlorine ( $\mathrm{HOCl}$ and $\left.\mathrm{OCL}^{-}\right)$and chloramines $\left(\mathrm{NH}_{2} \mathrm{Cl}\right)$ is depicted in Figure 2.1 at $10^{-4} \mathrm{M}$ chlorine concentration and $25^{\circ} \mathrm{C}$. As shown in Figure 2.1, the oxidation-reduction potential (ORP) of free chlorine is greater than the potential of chloramines, and both exist in a region where water is not stable. In the stable region of water, chlorides are the dominant species, which is why the presence of residual is desirable in drinking water as it move to equilibrium and deactivates pathogens in the process. The 
subsequent reaction of either free chlorine or chloramines with metals in distribution systems will form different compounds that can affect corrosion (Schock, 1999).

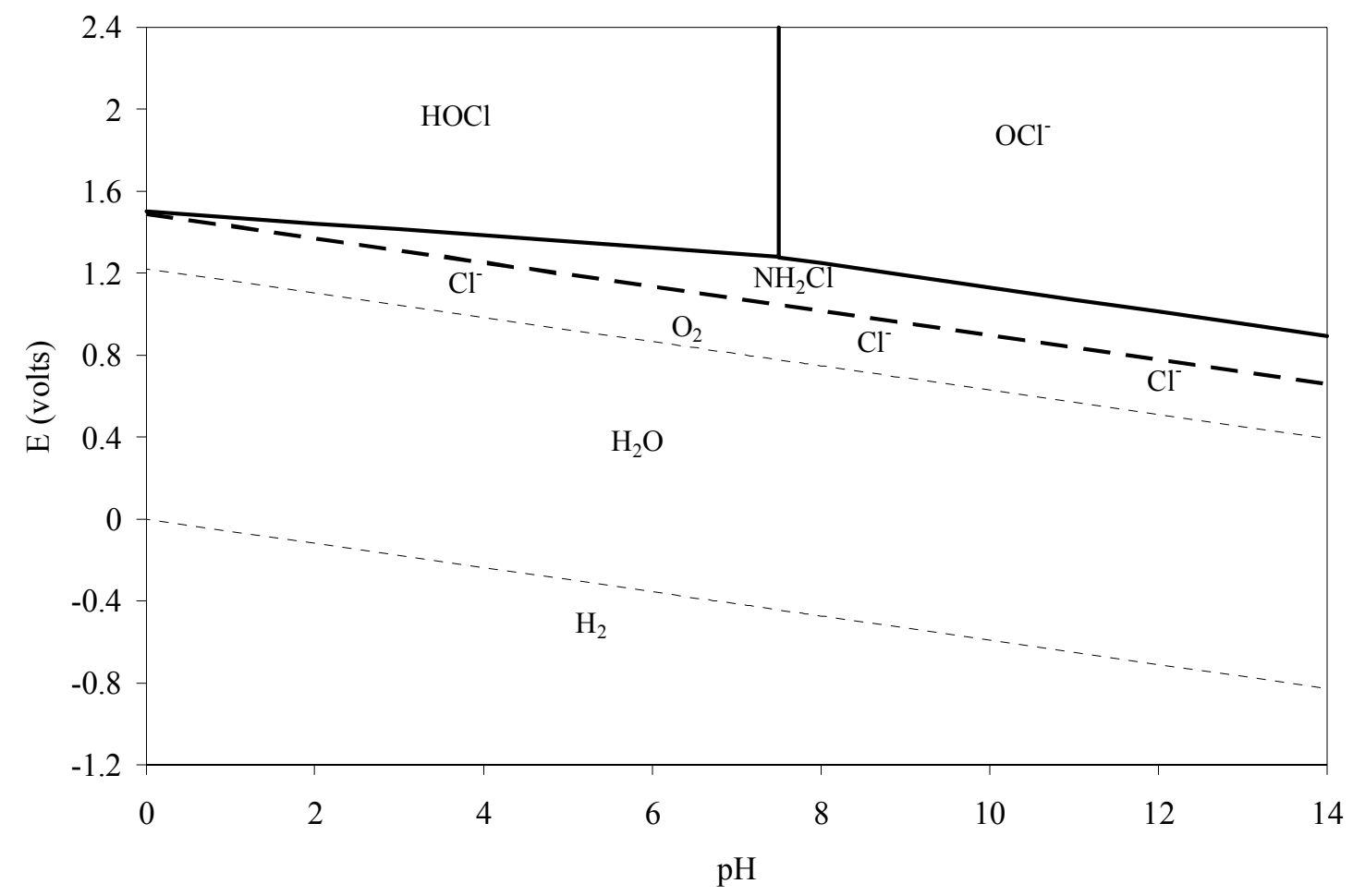

Figure 2.1 Electrochemical potential comparison of free chlorine and chloramines in water at $25^{\circ} \mathrm{C}$. Free chlorine concentration $=10^{-4} \mathrm{M}$, Chloramines concentration $=10^{-4} \mathrm{M}$ and Ammonia concentration $=10^{-3} \mathrm{M}$.

Examination of actual lead corrosion by free chlorine and chloramines has been studied in practice. Lead corrosion in drinking water is defined by regulation to include dissolved and particulate lead. Physical effects such as turbulence, frequency of stagnation, and movement of valves can disrupt the solid films and increase lead release. Film disruption is also affected by water quality that prevents the adherence of precipitated solids to pipe surfaces or promotes the formation of porous layers (Leroy, 1993; Lytle, 1993 \& 2000; and Schock, 1990 \& 1989).

Treweek et al. (1985) investigated corrosion rates of different piping materials in the presence of free chlorine and chloramines in an aqueous environment. A fine powdery material 
was barely visible on the surface of lead-tin solder coated copper inserts. A yellowish-brown film formed on the inner surface of lead pipe inserts and a green coating of powder formed on the copper coil tubing surfaces exposed to the free chlorine and chloramine residuals. The corrosion layers developed on the metals after three months and changed little throughout the study.

Corrosion and penetration rates are measured by weight loss of metal coupons due to scale removal following exposure to aqueous environments. Metal concentrations may or may not correlate to corrosion and penetration rates measured by weight loss. The corrosion and penetration rates of lead inserts were higher in a free chlorine environment than in a chloramine environment. Free chlorine and chloramines corrosion and penetration rates for the lead-tin solder coated copper inserts were not different. Corrosion of copper coil tubing with lead-tin solder was assessed by measuring dissolved lead and copper concentrations and showed higher lead concentrations in the presence of the free chlorine than in the presence of chloramines.

Lin et al. (1997) also studied the release of total lead from lead, copper/lead solder, and brass coupons in a static batch for varying disinfectant (free chlorine and chloramines) and $\mathrm{pH}$. Total lead release from lead coupons $(99 \% \mathrm{~Pb})$ decreased as $\mathrm{pH}$ increased for both free chlorine and chloramines; however, total lead release was significantly higher in the presence of free chlorine than in the presence of chloramines at equivalent $\mathrm{pHs}$. The release of total lead from the copper/lead solder coupons $(50 / 50 \mathrm{Sn} / \mathrm{Pb})$ was similar to the release of total lead form the lead coupons. Increasing $\mathrm{pH}$ decreased total lead release and was higher in the presence of free chlorine by a factor of two. For the brass coupons containing $3 \%$ lead, increasing $\mathrm{pH}$ also decreased total lead release, but conversely in the presence of chloramines total lead release increased. 
Cantor et al. (2003) investigated lead corrosion over time in raw, free chlorine and free chlorine plus corrosion treated ground waters. Corrosion treatment consisted of $\mathrm{pH}$ control using $\mathrm{NaOH}$ in a low alkalinity - low hardness ground water and orthophosphate addition in a high alkalinity - high hardness ground water. The lead action level (AL) was exceeded in all waters at all times during the study, but after one year lead release in the free chlorine with orthophosphate decreased to the AL. Lead concentrations in chlorinated waters were equal to or less than lead concentrations in untreated water, which indicated no adverse effects of free chlorine on lead release for these conditions. Although all waters exceeded the lead AL at some time, the results indicated that treatment was necessary to control lead release in these conditions, and was only accomplished by orthophosphate addition.

Edwards et al. (2004) investigated lead solubility and lead release from lead pipes and brass in waters without disinfectant, with ammonia, with free chlorine, and with chloramines at varying pHs. All waters were dosed with $5 \mathrm{mg} / \mathrm{L}$ of $\mathrm{Pb}$ using $\mathrm{PbCl}_{2}$ in the solubility study. Dissolved and total lead release in solubility tests of waters without disinfectant or with chloramines were four to six times greater than in waters with free chlorine from $\mathrm{pH} 7.5$ to 9 . Lead release decreased slightly as $\mathrm{pH}$ increased from $\mathrm{pH} 7.5$ to 9 . However, the lead pipes studies found that total lead concentrations were not statistically different at 2 and 30 days. The soluble lead fraction was $66 \%$ of the total lead release in presence of chloramines as compared to $3-30 \%$ in other waters.

Edwards found higher lead release from seven of eight different brass hose bibs that varied in $\mathrm{Pb}$ content (2 to 8\%) over a 58 day study period in the presence of chloramines. Additional analysis on brass was done by adding $10 \mathrm{mg} / \mathrm{L}$ of $\mathrm{NO}_{3}-\mathrm{N}$ to the waters after two months. With or without disinfectants, lead release increased after nitrate addition in waters in 
contact with the seven of eight brass hose bibs. In a longer-term examination with the presence of nitrates, Edwards describes that chloramines leached less lead than free chlorine with the same type of water.

The effect of chloramines on total lead release in drinking water distribution systems has been reported by the Water and Sewer Authority (WASA) in Washington D.C. WASA switched from free chlorine to chloramine residual maintenance in 2000 for control of DBP formation (Leonnig, 2000; and Nakamura, 2004). As early as mid 2001 through 2003, WASA exceeded the Pb AL $15 \mu \mathrm{g} / \mathrm{L}$ (Nakamura, 2004; and Holder, 2004). Some of the lead concentrations significantly exceeded AL as highlighted by total lead concentrations of 48,000 and $24,000 \mu \mathrm{g} / \mathrm{L}$ from two homes (Nakamura et al., 2004).

WASA uses a one-month free chlorine burn every spring to control bacterial growth in the distribution system and reported in 2004 the fraction of homes exceeding the $\mathrm{Pb} \mathrm{AL}$ decreased from 54 to $26 \%$ following the one-month free chlorine burn. In one home, the lead concentration fell tenfold (Cohn, 2004). Once chloramines was reintroduced to the distribution system, lead concentrations increased by a factor of 13.6 (Edwards et al., 2004).

The results from these investigations indicate that lead release from lead pipes increases when free chlorine is used for residual maintenance relative to chloramines (Treweek et al., 1985; Lin et al., 1997; and Edwards et al., 2004) and that released lead is greater or equal with free chlorine residual maintenance than with no disinfectant (Cantor et al., 2003 and Edwards et al., 2004). These observations are supported by the greater ORP of free chlorine relative to chloramines (Singer et al., 1999). But, when lead is coupled with another metal, such as in brass fixtures, soldered joints or in the distribution system where different pipe materials are connected, lead release is greater in the presence of chloramines relative to free chlorine as 
shown by Treweek et al.(1985), Lin et al. (1997), and Edwards et al. (2004). Galvanic cells are one corrosion mechanism that is applicable to drinking water. Solder joints in brass fixtures connect dissimilar metals such as lead, zinc or copper in brass alloys or pipes to lead, tin, and silver in solder, which creates an galvanic cell resulting in lead release. Galvanic corrosion of the 23,000 lead and 107,000 copper pipes has been suggested as a mechanism for increased lead release in the WASA distribution and consumer home plumbing systems following a change from free chlorine to chloramine residual maintenance (Nakamura, 2004 and Nakamura et al., 2004).

Additionally, the dissipation of chloramines to free ammonia can facilitate ammonia oxidizing bacteria to nitrify and produce nitrates $\left(\mathrm{NO}_{3}{ }^{-}\right)$. Edwards et al. (2004) demonstrated lead release caused by the addition of $10 \mathrm{mg} / \mathrm{L}-\mathrm{NO}_{3}-\mathrm{N}$ to water in the presence of chloramines exceeded lead release in the presence of free chlorine. Other research has also shown high concentrations of nitrates increase lead release (Amin et al., 2004; Uchida et al., 1999; and Abd El Rehim et al., 1998). These studies demonstrated that in the presence of nitrates, dissolution of lead occurs and passive lead scales break down, which may add to the total lead concentration. 


\section{METHODS AND MATERIALS}

\section{$\underline{\text { 3.1 Pourbaix Diagrams }}$}

The thermodynamic demonstration of the oxidation-reduction of lead consisted of constructing Pourbaix diagrams. The Pourbaix diagrams were created for the speciation of lead in water, accounting for the lead hydroxide, oxide and carbonate species. The reactions with lead and their associated Gibb's free energy were determined from literature, as well for the reactions of chlorine. Sources used for the construction of the Pourbaix diagrams for lead and chlorine are Schock (1999), AWWARF (1985), and Snoeyink et al. (1980).

\section{$\underline{\text { 3.2 ORP Titrations }}$}

Finished waters, prior to disinfection, were collected from the Tampa Bay Water (TBW) Regional Surface Water Treatment Plant in Brandon, FL; the TBW Desalination Water Treatment Plant in Tampa, FL; and the TBW Cypress Creek well field near the city of Land O'Lakes, FL. Blended water was made from $62 \% \mathrm{GW}, 27 \% \mathrm{SW}$, and $11 \%$ RO finished waters.

Prior to the experiment, the initial chlorine residual of the waters were measured to verify no chlorine residual. The concentration of free chlorine or chloramines in the titrant was 20 and $1000 \mathrm{mg} / \mathrm{L}$ as $\mathrm{Cl}_{2}$. ORP of the water was measured using an oxidation-reduction probe, a silversilver chloride reference electrode with saturated potassium chloride and a platinum indicator electrode. The ORP measurement was conducted and then converted relative to the standard 
hydrogen electrode. Titration continued until a $10 \mathrm{mg} / \mathrm{L}$ as $\mathrm{Cl}_{2}$ was achieved. Chlorine concentrations were measured after titrations were complete. Free chlorine and chloramine titrations were done on (a) all source waters at $5,15,25$ and $30{ }^{\circ} \mathrm{C}$ (b) RO finished water with $35.5,71$, and $106.5 \mathrm{mg} / \mathrm{L}$ of $\mathrm{Cl}^{-}$addition at $25^{\circ} \mathrm{C}$ and (c) SW finished water with 50, 100, and $150 \mathrm{mg} / \mathrm{L}$ of $\mathrm{SO}_{4}^{-2}$ at $25^{\circ} \mathrm{C}$.

\section{$\underline{3.3} \underline{\text { Lead Field Study }}$}

The field study was conducted at a large pilot facility near the city of Land O'Lakes, FL at the Tampa Bay Water Cypress Creek well field. RO, surface, ground, and blended finished waters were distributed to eight identical pilot distribution systems (PDS) as shown in Figure 3.1. The first four PDSs received ground, surface, RO, and blended finished waters and used free chlorine for residual maintenance and the remaining four PDSs received identical finished waters and used chloramines for residual maintenance. The PDSs were identical and were made from actual distribution system pipes which discharged to a corrosion shed that housed copper coil tubing with lead coupon inserts as shown in Figure 3.2.

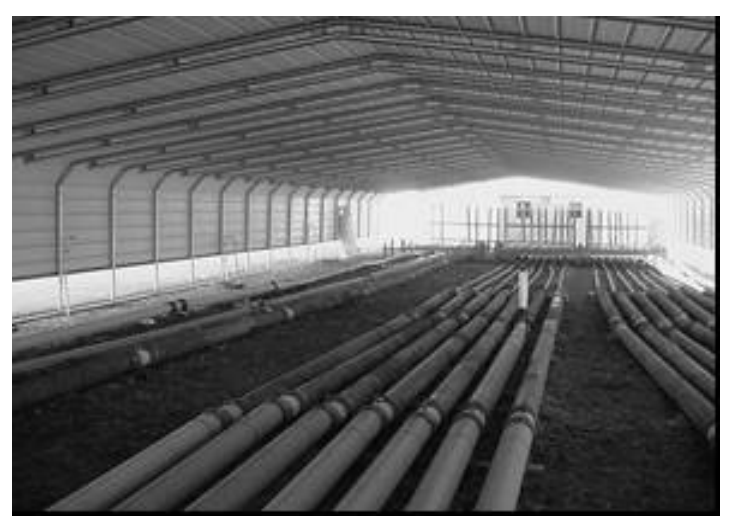

Figure 3.1 Influent treated water to pilot distribution system

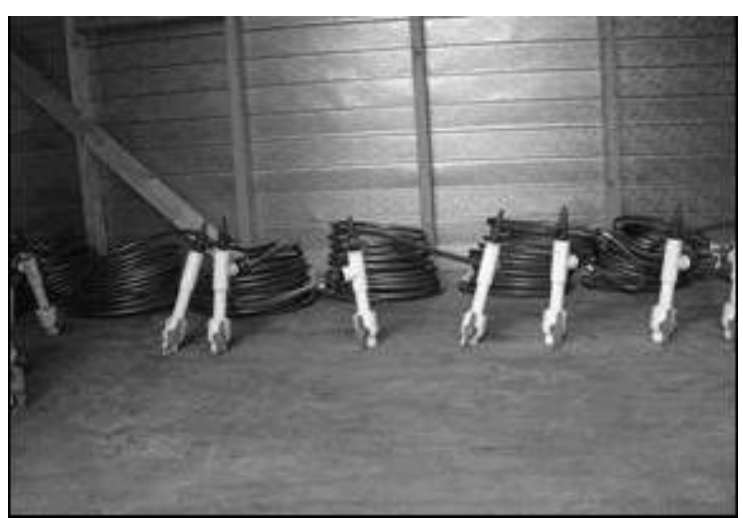

Figure 3.2 Copper coil tubing with lead coupons in corrosion shed 
The field experiment was done as the final phase of a two year field study and lasted 3 months. Weekly samples were collected from the corrosion shed following flushing of two gallons and a 6 to 8 hour stagnation period. A one liter sample was collected for water quality measurement. The methods used to measure water quality are listed in Table 3.1.

Table 3.1 Water quality parameters and methods

\begin{tabular}{|c|c|c|}
\hline Parameter & Method & Units \\
\hline $\mathrm{pH}$ & $\mathrm{SM} 4500-\mathrm{H}^{+} \mathrm{B}$ & $\mathrm{pH}$ units \\
\hline Alkalinity & SM 2320 B & $\mathrm{mg} / \mathrm{L}$ as $\mathrm{CaCO}_{3}$ \\
\hline Chlorides, $\mathrm{Cl}^{-}$ & SM $4110 \mathrm{~B}$ & $\mathrm{mg} / \mathrm{L}$ \\
\hline Sulfates, $\mathrm{SO}_{4}^{-2}$ & SM $4110 \mathrm{~B}$ & $\mathrm{mg} / \mathrm{L}$ \\
\hline Lead & SM 3113 B & $\mu \mathrm{g} / \mathrm{L}$ \\
\hline Nitrate, $\mathrm{NO}_{3}^{-}$ & Hach 8507 & $\mathrm{mg} / \mathrm{L}$ as $\mathrm{N}$ \\
\hline Ammonia & SM 4500 NH3 D & $\mathrm{mg} / \mathrm{L}$ as $\mathrm{N}$ \\
\hline Free chlorine & $\mathrm{SM} 4500-\mathrm{Cl} \mathrm{G}$ & $\mathrm{mg} / \mathrm{L}$ as $\mathrm{Cl}_{2}$ \\
\hline Total Chlorine & $\mathrm{SM} 4500-\mathrm{Cl} \mathrm{G}$ & $\mathrm{mg} / \mathrm{L}$ as $\mathrm{Cl}_{2}$ \\
\hline Potential (ORP) & SM 2580 B & volts \\
\hline HPC & SM 9215 C & $\mathrm{cfu} / \mathrm{mL}$ \\
\hline PEPA & Laurent et al. (1995) & cells $/ \mathrm{cm}^{2}$ \\
\hline
\end{tabular}




\section{RESULTS AND DISCUSSION}

\section{$\underline{4.1}$ Total lead release field study}

The effects of free chlorine and chloramines residuals on total lead release in the pilot distribution systems were compared over a three month period by water source and water quality using identical water sources, PDSs and PDS operating conditions. The PDS hydraulic retention time (HRT) during this period was two days, which corresponded to a 10.8 mile equivalent pipe length in an actual distribution system flowing at $0.33 \mathrm{ft} / \mathrm{sec}$. All statistical comparisons of free chlorine and chloramine distribution water quality were made using paired t-tests to determine statistically significant differences at a $95 \% \mathrm{CL}$.

The actual and variation of total lead release is shown in Figure 4.1 for each source and the average of all sources in free chlorine and chloramine environments. As shown in Figure 4.1, the average release of total lead to GW, SW, RO and blended finished waters was $34.9 \mu \mathrm{g} / \mathrm{L}$ in the presence of chloramines and $4.4 \mu \mathrm{g} / \mathrm{L}$ in the presence of free chlorine. The magnitude of the greater average total release in the presence of chloramines is primarily due to the relatively high average lead release to the RO finished water in the presence of chloramines as shown in Table 4.1. As shown in Figure 4.1, there was significant variation in total lead release, especially in the RO finished water, which was attributed to particulate release and water quality. Total lead release was associated with high chloride concentrations, which may have adversely affected passivating lead films. Average total lead releases was higher in RO and B finished 
water in the presence of chloramines, but there was no statistically significant difference in total lead release in the presence of either free chlorine or chloramines for GW or SW. These results are consistent with trends reported by other investigators (Treweek et al., 1985; Lin et al., 1997; and Edwards et al., 2004).

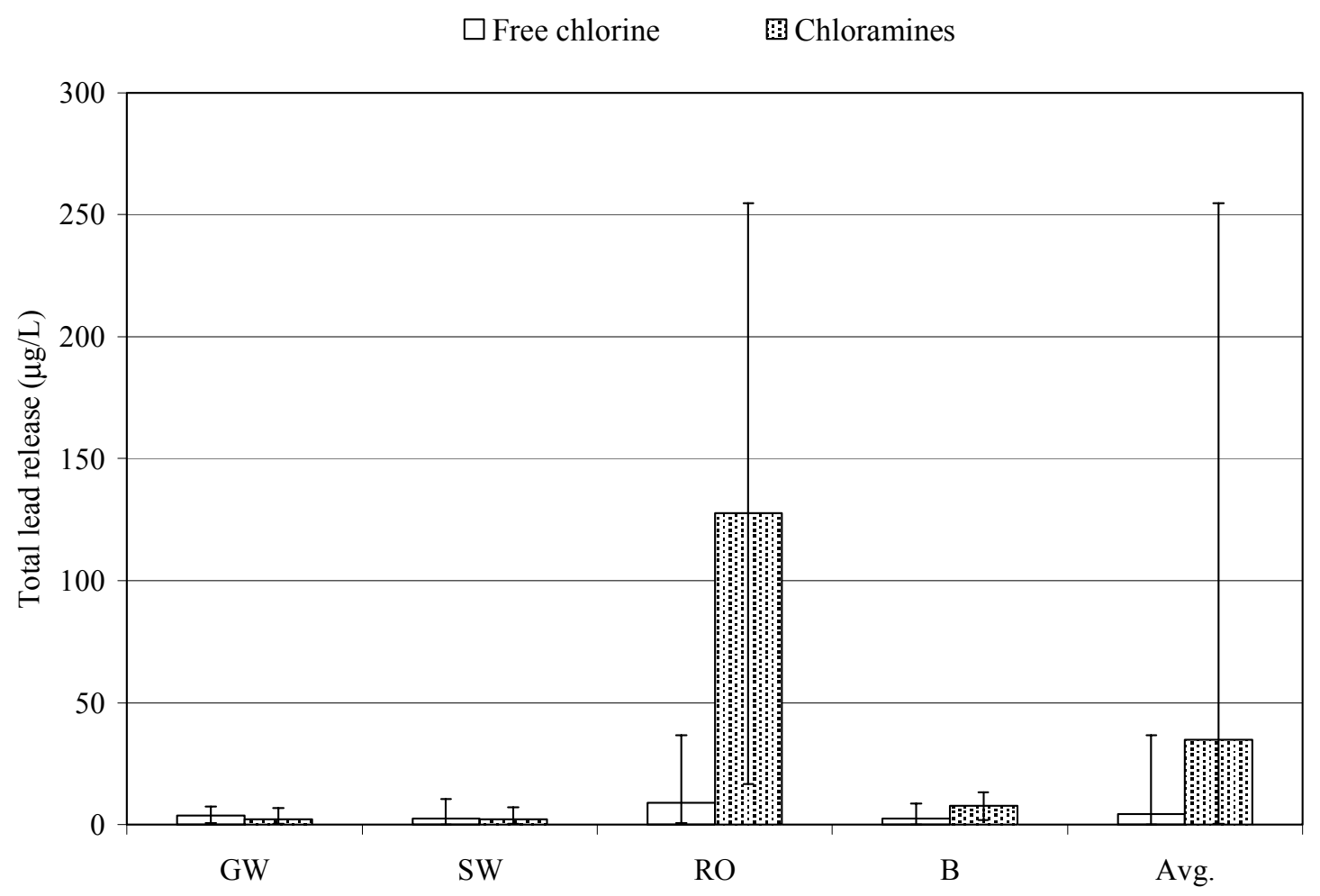

Figure 4.1 Average lead release by source and disinfectant 


\begin{tabular}{|c|c|c|c|c|c|c|c|c|c|}
\hline 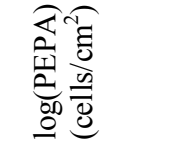 & ก̋ & $\vec{a}$ & $\begin{array}{l}\infty \\
\infty \\
\infty\end{array}$ & $\begin{array}{l}0 \\
\infty\end{array}$ & $\stackrel{\circ}{\circ}$ & $\tilde{a}$ & $\stackrel{\infty}{\infty}$ & $\stackrel{b}{\circ}$ & $\nabla$ \\
\hline 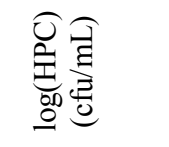 & $\ddot{n}$ & $\stackrel{\circ}{\ddot{r}}$ & $\stackrel{m}{n}$ & $\hat{i}$ & $\exists$ & $\stackrel{b}{\dot{r}}$ & $\stackrel{\bullet}{\dot{r}}$ & $\stackrel{\vec{r}}{\oplus}$ & $\simeq$ \\
\hline 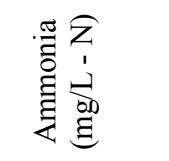 & $\stackrel{0}{\circ}$ & $\stackrel{\square}{\circ}$ & $\stackrel{\overline{0}}{\circ}$ & $\stackrel{\square}{\circ}$ & f̊ & $\stackrel{\text { I̦. }}{0}$ & $\hat{n}$ & $\begin{array}{l}0 \\
\stackrel{2}{0} \\
0\end{array}$ & $\nabla$ \\
\hline 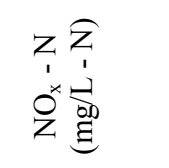 & $\stackrel{0}{0}$ & $\stackrel{7}{\circ}$ & $\stackrel{\text { ô }}{0}$ & $\stackrel{t}{0}$ & $\stackrel{n}{\dddot{c}}$ & $\stackrel{\text { I̦ }}{0}$ & $\stackrel{ \pm}{0}$ & $\stackrel{m}{0}$ & $m$ \\
\hline 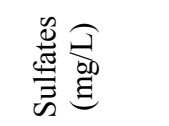 & $\stackrel{n}{2}$ & $\hat{\tilde{I}}$ & $\vec{r}$ & $\underset{\overbrace{}}{2}$ & $\stackrel{+}{\stackrel{+}{d}}$ & 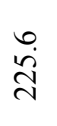 & $\stackrel{+}{+}$ & $\vec{n}$ & $=$ \\
\hline 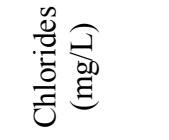 & $\stackrel{\leftrightarrow}{\stackrel{\sim}{े}}$ & $\stackrel{\circ}{\stackrel{\sim}{0}}$ & $\stackrel{m}{n}$ & $\underset{\infty}{\stackrel{\sim}{\sim}}$ & $\begin{array}{l}\infty \\
\underset{\lambda}{ }\end{array}$ & $\frac{m}{m}$ & 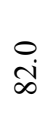 & $\underset{\text { ì }}{\stackrel{\sim}{n}}$ & $=$ \\
\hline$=\frac{\widehat{x}}{0}$ & $\stackrel{\infty}{0}$ & $\stackrel{\infty}{0}$ & $\grave{o}$ & $\stackrel{\infty}{0}$ & $\stackrel{0}{0}$ & $\hat{o}$ & $\stackrel{0}{0}$ & $\stackrel{0}{0}$ & $\simeq$ \\
\hline 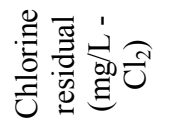 & $\stackrel{\infty}{0}$ & $\stackrel{\text { I }}{\rightarrow}$ & 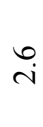 & $\stackrel{\odot}{-}$ & $\tilde{o}$ & $\stackrel{\nabla}{0}$ & $\stackrel{0}{0}$ & $\stackrel{\infty}{0}$ & $\simeq$ \\
\hline 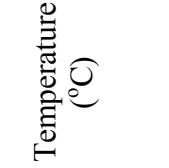 & $\stackrel{\infty}{\sim}$ & $\stackrel{\infty}{\sim}$ & $\stackrel{\infty}{\sim}$ & $\stackrel{\infty}{\sim}$ & $\stackrel{\infty}{\sim}$ & $\stackrel{\infty}{\sim}$ & $\stackrel{\infty}{\sim}$ & $\stackrel{\infty}{\sim}$ & $\mathscr{0}$ \\
\hline 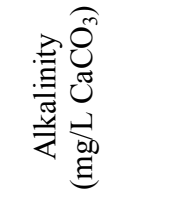 & $\hat{a}$ & 8 & $\approx$ & $\stackrel{g}{\mathcal{I}}$ & 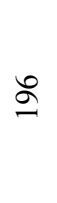 & $\hat{\sigma}$ & $\mathbb{N}$ & $\stackrel{8}{0}$ & $\stackrel{m}{-1}$ \\
\hline$\stackrel{I}{2}$ & $\stackrel{\circ}{\infty}$ & $\stackrel{\infty}{\infty}$ & $\stackrel{m}{\infty}$ & $\vec{\infty}$ & $\stackrel{\infty}{\stackrel{\infty}{r}}$ & $\stackrel{ }{r}$ & $\stackrel{\infty}{\infty}$ & $\stackrel{9}{r}$ & $\underline{n}$ \\
\hline 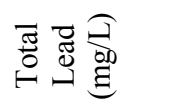 & $\dot{m}$ & $\hat{i}$ & $\stackrel{\partial}{\infty}$ & $\stackrel{+}{i}$ & $\underset{\sim}{\sim}$ & $\stackrel{n}{i}$ & 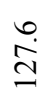 & $\stackrel{i}{r}$ & $a$ \\
\hline 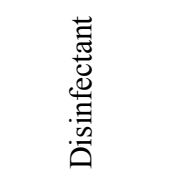 & 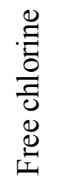 & 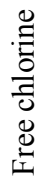 & 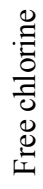 & 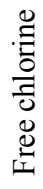 & 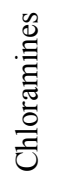 & 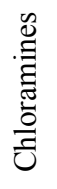 & 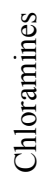 & 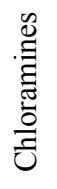 & 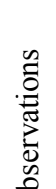 \\
\hline 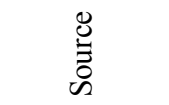 & 勇 & is & $\approx$ & 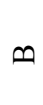 & 胥 & 合 & $\stackrel{0}{\approx}$ & 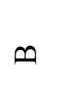 & $\begin{array}{l}\text { 岁 } \\
\#\end{array}$ \\
\hline
\end{tabular}


Tang (2005) developed empirical and fundamental equilibrium models based on speciation for total lead release during the investigation of water quality changes in distribution system water quality brought about by blending different waters (Tang, 2005 and Taylor et al., 2005). These models are shown in Equation 4.1 and Equation 4.2. The empirical model was developed in the presence of only a chloramine residual. A similar model was developed by Schock $(1980 ; 1981 \& 1983)$ based on the assumption that $\mathrm{Pb}_{3}(\mathrm{OH})_{2}\left(\mathrm{CO}_{3}\right)_{2}$ was the controlling solid phase for lead release. In his model, only carbonate and hydroxide complexes were considered. The complexes with chloride and sulfate were not included since their contributions are small compared to carbonate and hydroxide complexes. Schock's model successfully predicted soluble lead release when approximate equilibrium was achieved. Lead mass transfer is commonly limited by diffusion in home plumbing systems when lead solder is the source for lead release.

$$
\begin{aligned}
& \mathrm{DIPb}=\left[\mathrm{Pb}^{2+}\right]+4\left[\mathrm{~Pb}_{4}(\mathrm{OH})_{4}{ }^{4+}\right]+2\left[\mathrm{~Pb}_{2} \mathrm{OH}^{3+}\right]+\left[\mathrm{PbOH}^{+}\right]+3\left\{\mathrm{~Pb}_{3}(\mathrm{OH})_{4}{ }^{2+}\right] \\
& +6\left\{\mathrm{~Pb}_{6}(\mathrm{OH})_{8}{ }^{4+}\right]+\left[\mathrm{Pb}(\mathrm{OH})_{2}{ }^{0}\right]+\left[\mathrm{Pb}(\mathrm{OH})_{3}\right]+\left[\mathrm{Pb}(\mathrm{OH})_{4}{ }^{2}\right]+\left[\mathrm{PbCO}_{3}{ }^{0}\right] \\
& +3\left[\mathrm{~Pb}_{3} \mathrm{CO}_{3}{ }^{4+}\right]+2\left[\mathrm{~Pb}_{2} \mathrm{CO}_{3}{ }^{2+}\right]+\left[\mathrm{Pb}\left(\mathrm{CO}_{3}\right)_{2}{ }^{2}\right]+\left[\mathrm{PbHCO}_{3}{ }^{+}\right]+\left[\mathrm{PbSO}_{4}{ }^{0}\right] \\
& +\left[\mathrm{Pb}\left(\mathrm{SO}_{4}\right)_{2}{ }^{2}\right]+\left[\mathrm{PbCl}^{+}\right]+\left[\mathrm{Pb}(\mathrm{Cl})_{2}{ }^{0}\right]+\left[\mathrm{Pb}(\mathrm{Cl})_{3}\right]+\left[\mathrm{Pb}(\mathrm{Cl})_{4}{ }^{2}\right]
\end{aligned}
$$

\section{Equation 4.1 Tang equilibrium model for soluble lead release}

$$
[P b]_{T}{ }_{90}=1.027^{(T-25)} \times \text { Alkalinity }^{0.677} \times p H^{-2.73} \times \text { Chloride }^{1.46} \times \text { Sulfate }^{-0.23}
$$

\section{Equation 4.2 Tang empirical model for lead release}

Where: $[\mathrm{Pb}]_{\mathrm{T}-90}=$ total lead release corresponding to $90^{\text {th }}$ percentile $(\mu \mathrm{g} / \mathrm{L})$

$$
\begin{aligned}
& \text { Alkalinity }=\mathrm{mg} / \mathrm{L} \text { as } \mathrm{CaCO}_{3} \\
& \text { Chloride }=\mathrm{mg} / \mathrm{L} \\
& \text { Sulfate }=\mathrm{mg} / \mathrm{L} \\
& \mathrm{T}=\text { Temperature, }{ }^{\circ} \mathrm{C}
\end{aligned}
$$


Ammonia complexes for lead have not been reported in the literature and do not impact lead release in drinking water. Hence, no lead-ammonia complexes were considered in either equilibrium, which indicates ammonia from chloramine degradation does not impact lead release in drinking water from the formation of lead complexes. The empirical model shown in Equation 4.2 was developed and verified using independent data over a year of operation during the blending effects study (Taylor et al., 2005). The data shown in Table 4.1 was not included in development or verification of the empirical total lead release model.

As predicted using Equation 4.1, the average soluble lead released during the comparison study is $165 \mu \mathrm{g} / \mathrm{L}, 95 \%$ of which are in the form of a lead-carbonate complexes. The empirical model shown in Equation 4.2 predicts $28 \mu \mathrm{g} / \mathrm{L}$ of total lead release for the average water quality conditions shown in Table 4.1. The actual average total lead release was $20 \mu \mathrm{g} / \mathrm{L}$, which is relatively close to the empirically predicted total lead lease. The equilibrium prediction was high because diffusion limited lead mass transfer limitations in the copper coils.

The data in Table 4.1 can be used to relate field water parameters to total lead release. There are no significant differences among source ORPs for a common disinfectant in the field. Chloramine ORP is always less than free chlorine ORP. As predicted in Equation 4.2, lead release tended to increase in the field with increasing chlorides and decrease with increasing sulfates. The highest lead release occurred in the RO finished water, which had the highest chlorides and the lowest sulfates. The lowest lead release occurred in the SW and GW finished waters, which had low chlorides and mixed sulfates. $\mathrm{NO}_{\mathrm{x}}\left(\mathrm{NO}_{2}{ }^{-}+\mathrm{NO}_{3}{ }^{-}\right)$is reported as an index for biological nitrification. 
Chloramines were used for residual maintenance in the PDSs receiving free chlorine during the comparison investigation. Biological nitrification was practically insignificant in the presence of chloramines and was not observed in the presence of free chlorine. Average $\Delta \mathrm{NO}_{\mathrm{x}}\left(\mathrm{NO}_{\mathrm{x}-\mathrm{out}}-\mathrm{NO}_{\mathrm{x} \text {-in }}\right)$ in the chloramine PDSs were $0.07 \mathrm{mg} / \mathrm{L}$ as $\mathrm{N}$ and 0.08 $\mathrm{mg} / \mathrm{L}$ as $\mathrm{N}$, respectively. Actual $\mathrm{NO}_{\mathrm{x}-\text { out }}$ varied from 0.42 to $0.02 \mathrm{mg} / \mathrm{L}$ as $\mathrm{N}$ because of nitrification in PDS storage tanks. Biological activity was significantly higher in the presence of chloramines. Average bulk water HPC was more than ten fold higher and average biofilm cell density was 2.6 fold higher in presence of chloramines relative to free chlorine. Finally, chloramine residual relative to free chlorine residual was lower in all finished waters. While this observation is surprising, lower chloramines residual were consistently observed during the comparison study. Chloramine residuals were accurately modeled and verified using independent data by Arevalo (2004) during the initial year of operation of the field study using data from eighteen PDSs as a function of water quality, pipe material, temperature and pipe geometry during the blending study (Arevalo et al., 2004; and Taylor et al., 2005). Arevalo demonstrated while bulk dissipation rate of chloramines was significantly less than the bulk dissipation rate of free chlorine, the wall reaction rate constants were much higher for chloramines than free chlorine, and more than compensated for the slower rate of chloramine bulk dissipation. As increased total lead release in the presence of chloramines relative to free chlorine has been documented in literature (Treweek et al., 1985; Lin et al., 1997; and Edwards et al., 2004), source water quality and disinfectant in the field studies can be related to lead release. While there are some water quality differences that can be attributed to the water source, these differences do not account for the increased total lead 
release in the presence of chloramines since source water qualities were practically identical with the exception of residual. There are no ammonia-lead complexes known in the literature, which practically eliminated ammonia as a cause of increased total lead release in the presence of chloramines. Investigators have reported total lead release increased as nitrates increased (Edwards et al., 2004; Amin et al., 2004; Uchida et al., 1999; and Abd El Rehim et al., 1998); however, the increased bulk nitrates in this work, are far below what has been observed to cause increases in total lead. Biological water quality as suggested (Schock, 1999) and field ORPs in the presence of both residuals are significantly different.

\section{$\underline{4.2}$ Effect of $\mathrm{Cl}_{2}$ and $\mathrm{NH}_{2} \underline{\mathrm{Cl} \text { on Drinking Water Potential }}$}

ORP was determined for varying $\mathrm{Cl}_{2}$ and $\mathrm{NH}_{2} \mathrm{Cl}$ residuals for the four finished waters produced from ground, surface, saline and blending as shown in Figure 4.2, Figure 4.3, Figure 4.4 and Figure 4.5. The purpose was to determine ORP differences by disinfectant, temperature, and source (Figure 4.2 and Figure 4.3) and then to determine if major anions added during SW treatment $\left(\mathrm{SO}_{4}^{-2}\right)$ or passing through $\mathrm{RO}$ filtration $\left(\mathrm{Cl}^{-}\right)$ would significantly increase ORP (Figure 4.4 and Figure 4.5). These ORPs would then be interpreted for their relative effects on lead release using the Pourbaix diagrams.

As shown in Figure 4.2, there is a significant difference in ORP between free $\mathrm{Cl}_{2}$ and $\mathrm{NH}_{2} \mathrm{Cl}$ residuals in stable $\mathrm{RO}$ finished water. ORP increases asymptotically to a maximum of approximately $0.9 \mathrm{~V}$ and $0.68 \mathrm{~V}$ for free $\mathrm{Cl}_{2}$ and $\mathrm{NH}_{2} \mathrm{Cl}$, respectively, at 25 ${ }^{\circ} \mathrm{C}$ and is very close to these values at concentrations used for residual maintenance in drinking water distribution systems. The trends of all ORP versus residual titration 
curves were similar in that ORP increased asymptotically to a maximum potential that was limited by disinfectant. Free $\mathrm{Cl}_{2}$ ORPs always exceeded $\mathrm{NH}_{2} \mathrm{Cl}$ ORPs.

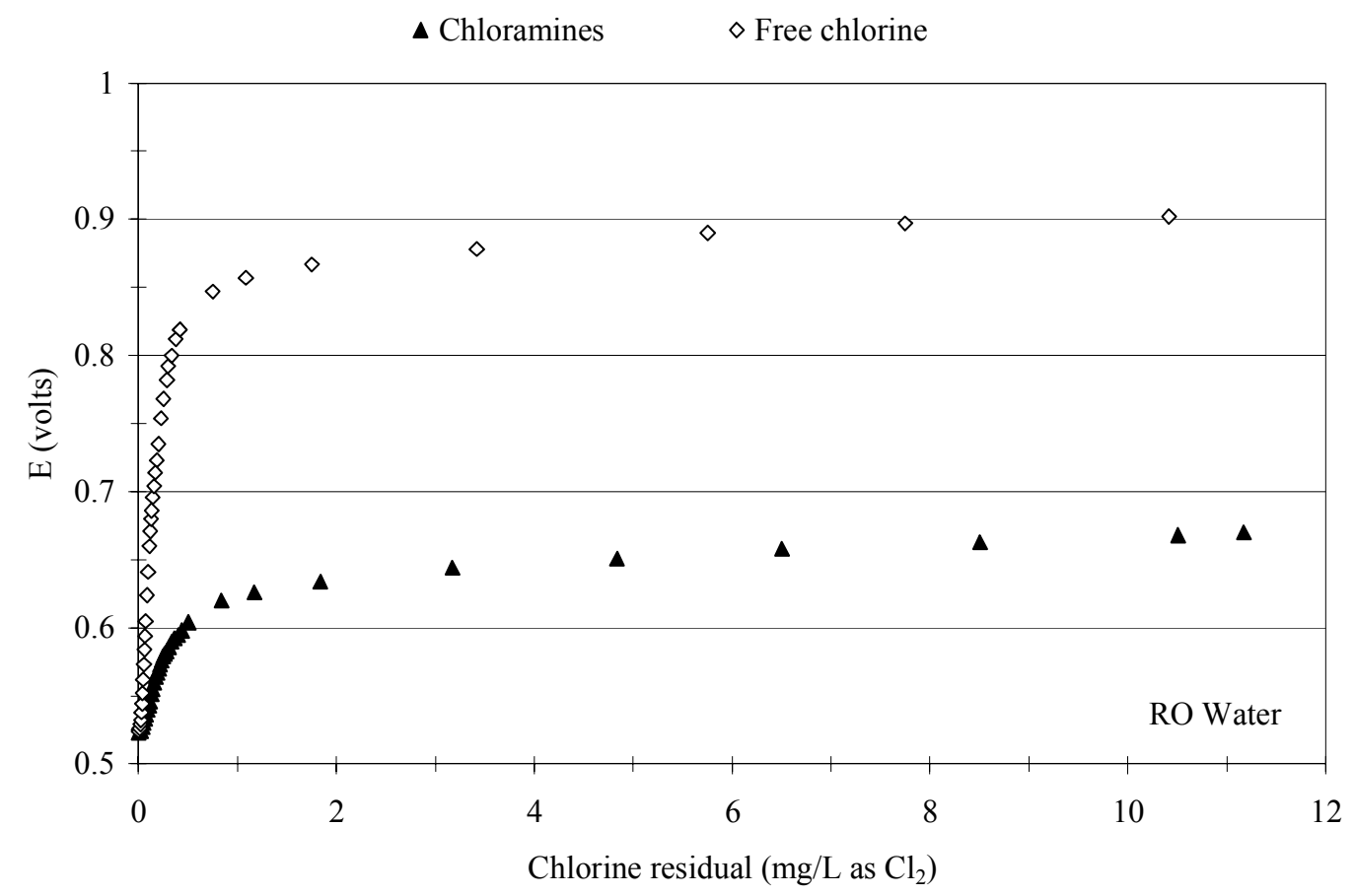

Figure 4.2 ORPs versus free $\mathrm{Cl}_{2}$ and $\mathrm{NH}_{2} \mathrm{Cl}$ for finished $\mathrm{RO}$ at $25^{\circ} \mathrm{C}$.

As shown in Figure 4.3, finished SW ORP decreased as temperature increased for both disinfectants. As shown in Figure 4.3 at 25 or $30^{\circ} \mathrm{C}$, the maximum finished RO ORP was approximately $0.9 \mathrm{~V}$ for free chlorine and $0.67 \mathrm{~V}$ for chloramines. However, at 5 or $15{ }^{\circ} \mathrm{C}$, the ORP was approximately $0.97 \mathrm{~V}$ for chlorine and $0.72 \mathrm{~V}$ for chloramines. This is consistent with equilibrium using the Nernst Equation in positive ORP conditions common to drinking water distribution systems. This observation was the same for all waters, ORP decreased as temperature increased. Additionally, source water did not affect ORP titrations. Figure 4.2 and Figure 4.3 demonstrate the effect of disinfectant and temperature was consistent for the different waters. At $25{ }^{\circ} \mathrm{C}$, the ORP for both RO and SW with free chlorine was about $0.9 \mathrm{~V}$ and with chloramines it was about $0.68 \mathrm{~V}$. 


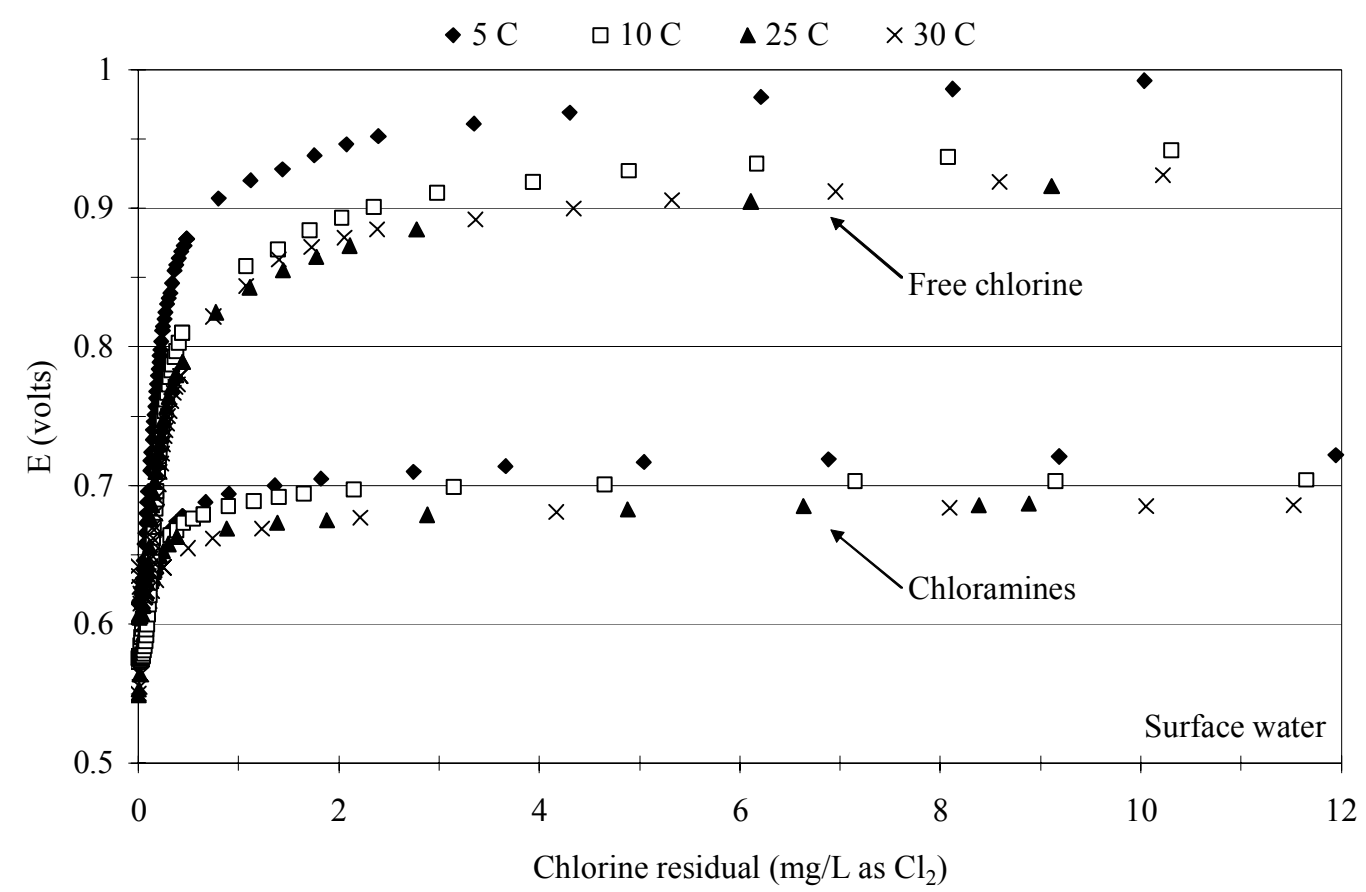

Figure 4.3 ORPs versus free $\mathrm{Cl}_{2}$ and $\mathrm{NH}_{2} \mathrm{Cl}$ for finished $\mathrm{SW}$ at different temperatures.

The titration presented in Figure 4.3 depicts equilibrium, which indicates equilibrium ORP decreases with increasing temperature. This is seemingly contrary to published literature that states lead corrosion rates increase with increasing temperature (Schock, 1999; AWWARF, 1985; and Boffardi, 1995 \& 1988) and is consistent with the Arrhenius Equation that infers reaction rates double in increments of $10{ }^{\circ} \mathrm{C}$. However, equilibrium constants often decrease with increasing temperature, which is consistent with the Nernst Equation for lead oxidation in common distribution system conditions.

Sulfates were added to finished surface water using $\mathrm{NaSO}_{4}$ to determine the effect of sulfate addition from enhanced coagulation on ORP, and chlorides were added to finished $\mathrm{RO}$ water using $\mathrm{NaCl}$ to determine the effect of additional chlorides in $\mathrm{RO}$ finished waters. As shown in Figure 4.4, the addition of $\mathrm{SO}_{4}{ }^{-2}$ to finished SW did little to 
affect ORP in the presence of free $\mathrm{Cl}_{2}$ or $\mathrm{NH}_{2} \mathrm{Cl}$. The same observation was made of the of the data shown in Figure 4.5 as the addition of chlorides did little to effect finished RO water ORP. Although some slight increases are apparent, the eventual ORPs of either finished water differed little with or without anion addition. However, the free chlorine and chloramines ORP differences were observed again in Figure 4.4 and Figure 4.5. Lead corrosion has been positively correlated with increasing chlorides (Schock, 1999; AWWARF, 1985) and increasing sulfates (Schock, 1999; AWWARF, 1985; and Taylor et al., 2005). However, the data presented in Figure 4.4 and Figure 4.5 suggests that these effects are not due to associated ORP increases.

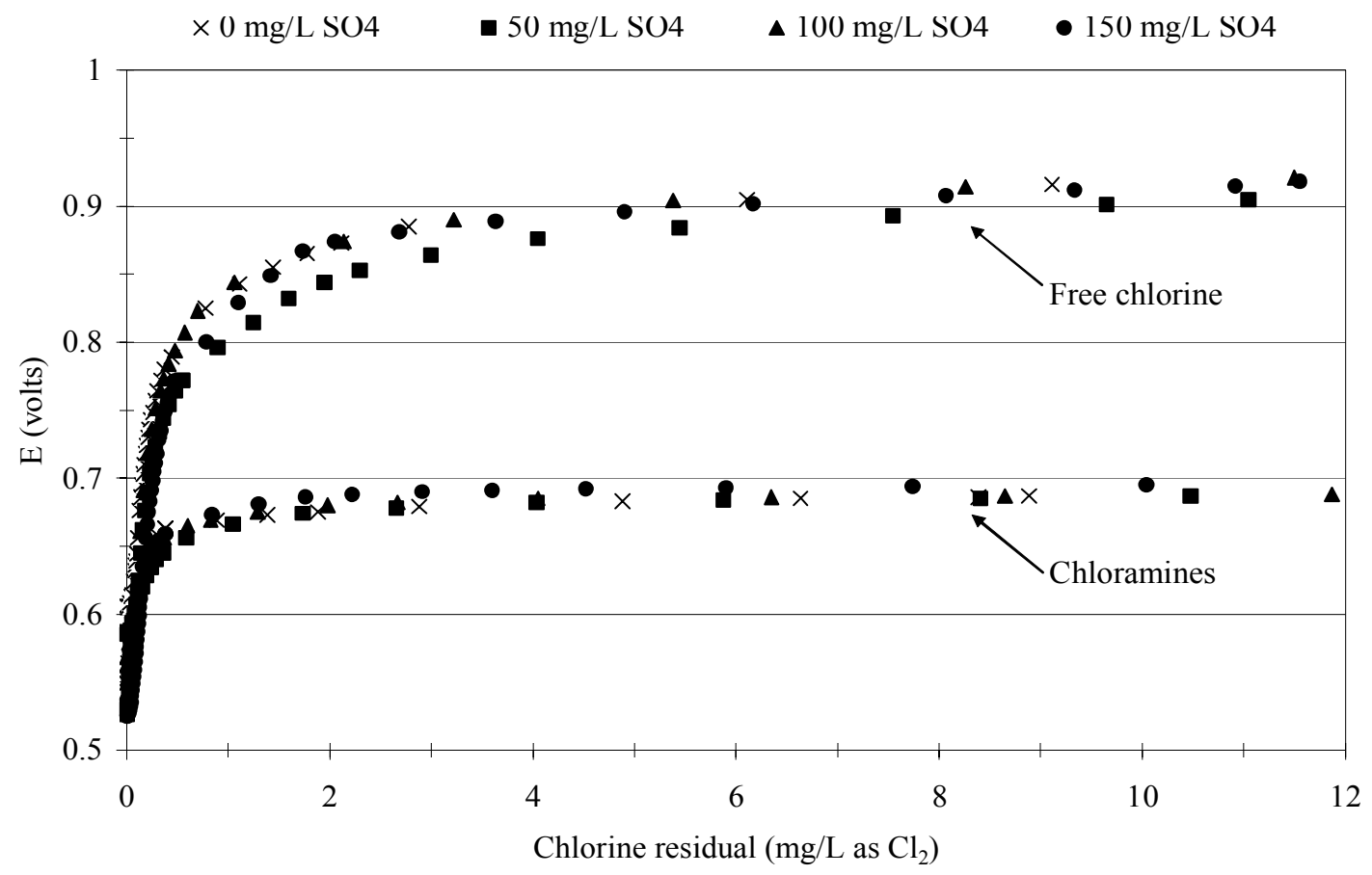

Figure 4.4 Effect of increasing sulfate addition on finished surface water ORP for varying free chlorine and chloramine residuals at $25^{\circ} \mathrm{C}$ 


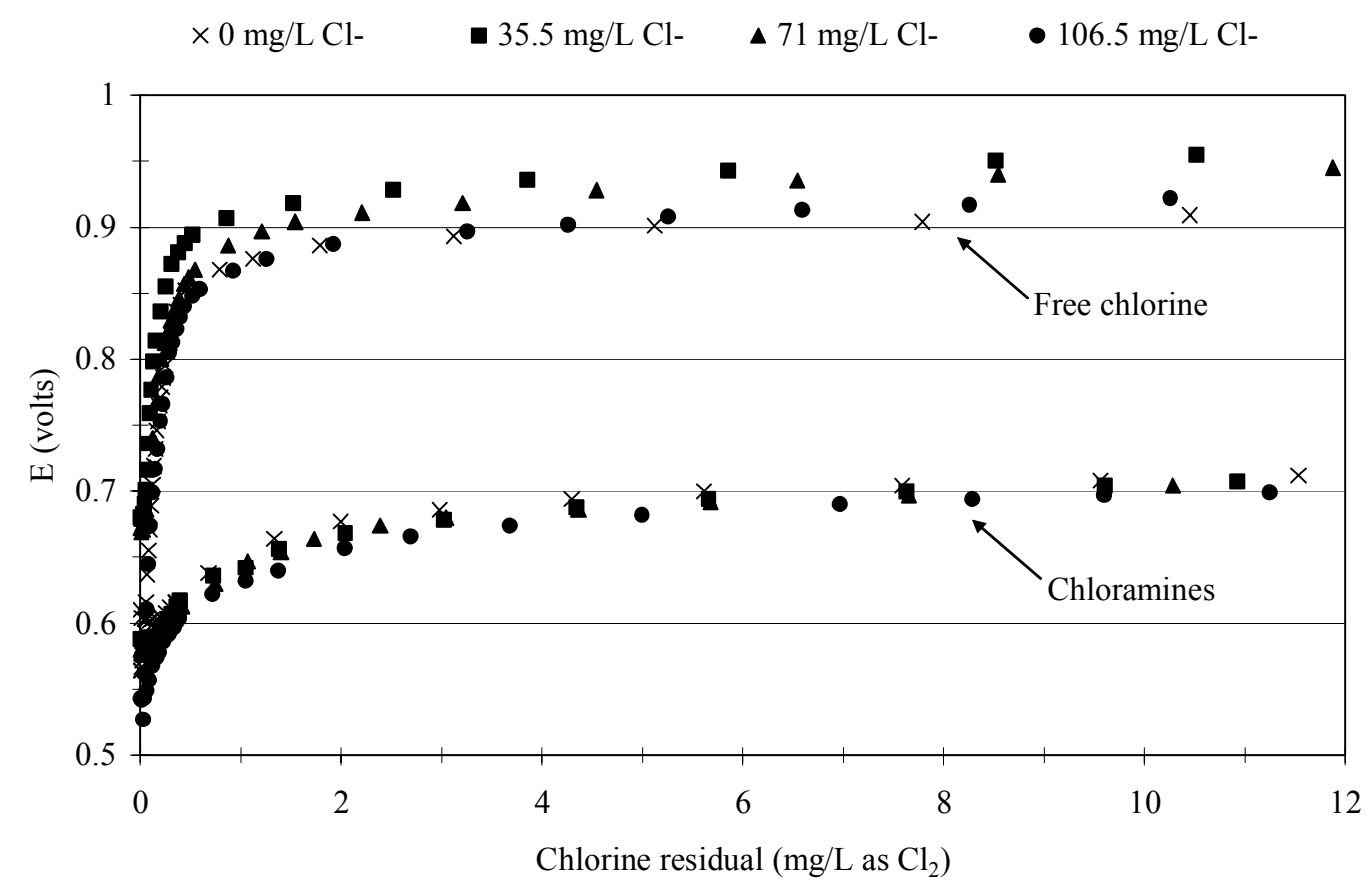

Figure 4.5 Effect of increasing chloride addition on finished RO water ORP for varying free chlorine and chloramine residuals at $25^{\circ} \mathrm{C}$.

\section{$\underline{4.3}$ Corrosion Thermodynamics}

Pourbaix diagrams considered lead species $\mathrm{Pb}_{(\mathrm{s})}, \mathrm{Pb}^{2+}, \mathrm{PbO}_{(\mathrm{s})}, \mathrm{PbO}_{2(\mathrm{~s})}, \mathrm{Pb}(\mathrm{OH})^{+}$, $\mathrm{Pb}(\mathrm{OH})_{2}{ }^{0}, \mathrm{~Pb}(\mathrm{OH})_{3}{ }^{-}, \mathrm{Pb}(\mathrm{OH})_{4}{ }^{-2}, \mathrm{PbO}_{3}{ }^{-2}, \mathrm{PbCO}_{3(\mathrm{~s})}($ cerussite $)$ and $\mathrm{Pb}_{3}\left(\mathrm{CO}_{3}\right)_{2}(\mathrm{OH})_{2(\mathrm{~s})}$ (hydrocerussite) and were developed for dominant species as shown in Figure 4.6 and Figure 4.7 for low $\left(50 \mathrm{mg} / \mathrm{L}\right.$ as $\left.\mathrm{CaCO}_{3}\right)$ and high $\left(200 \mathrm{mg} / \mathrm{L}\right.$ as $\left.\mathrm{CaCO}_{3}\right)$ alkalinities, respectively. Similar diagrams have been developed and are continually used to demonstrate controlling species and phases in redox reactions (Schock, 1999; 1981; 1980; AWWARF, 1985; Hem, 1973; and Pourbaix, 1966). Figure 4.6 and Figure 4.7 show the predominance of solid phases controlling soluble lead release at equilibrium for water quality conditions common to drinking as indicated by the shaded areas in those 
figures. As demonstrated by Schock, continually refinement and interpretation of these diagrams provides insight into metal release as controlled by solubility of controlling phases and even particle release as lead oxide solid phases are recognized as less soluble more durable than lead carbonates and less likely to break apart than lead carbonate solid phases (Renner, 2004).

Common distribution system water quality conditions in drinking water are shown in Figure 4.6 and Figure 4.7 as the shaded area defined by $\mathrm{pH}, \mathrm{E}$ and $\mathrm{pC} \mathrm{C}_{\mathrm{Pb}}$. Although lead is immune to corrosion where $\mathrm{Pb}_{(\mathrm{s})}$ is predominant, this only occurs in areas of unstable water and below pH 5, which do not exist in drinking water. Consequently, the controlling solid phases for lead at the potential generated by chloramine residual maintenance are lead carbonate $\left(\mathrm{PbCO}_{3(\mathrm{~s})}\right.$ or cerussite) and basic lead carbonate $\left(\mathrm{Pb}_{3}\left(\mathrm{CO}_{3}\right)_{2}(\mathrm{OH})_{2}\right.$ or hydrocerussite), and is $\mathrm{PbO}_{2}$ for lead at the potential generated by free chlorine residual maintenance as shown in Figure 4.6 and Figure 4.7. 


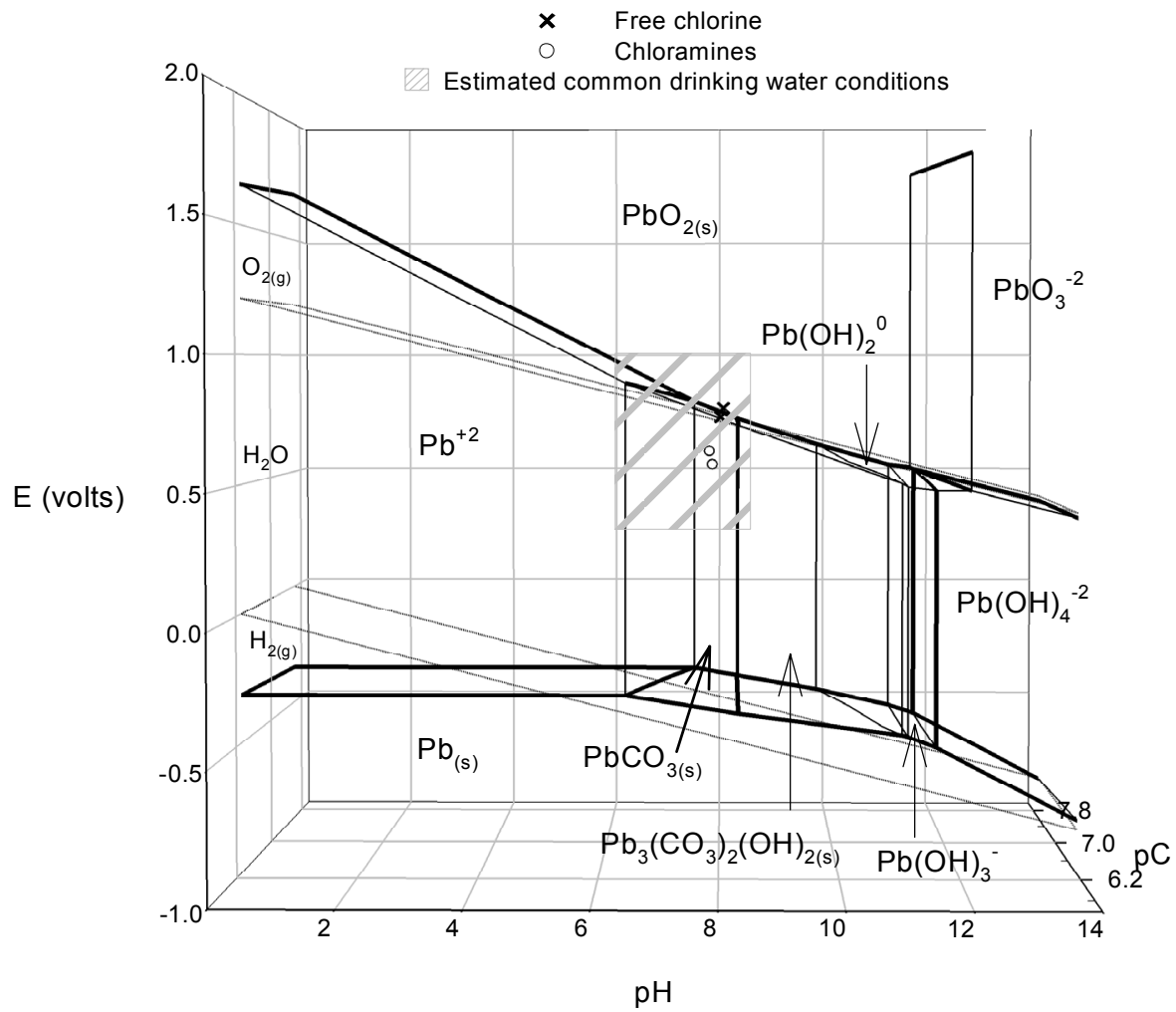

Figure 4.6 Lead potential versus $\mathrm{pH}$ and $\mathrm{pC}_{\mathrm{pb}}$ showing average total lead release and predominant lead species for groundwater and blended water quality conditions in field studies for free chlorine and chloramines. Alkalinity $=\mathbf{2 0 0} \mathbf{~ m g} / \mathrm{L}$ $\mathrm{CaCO}_{3}$. 


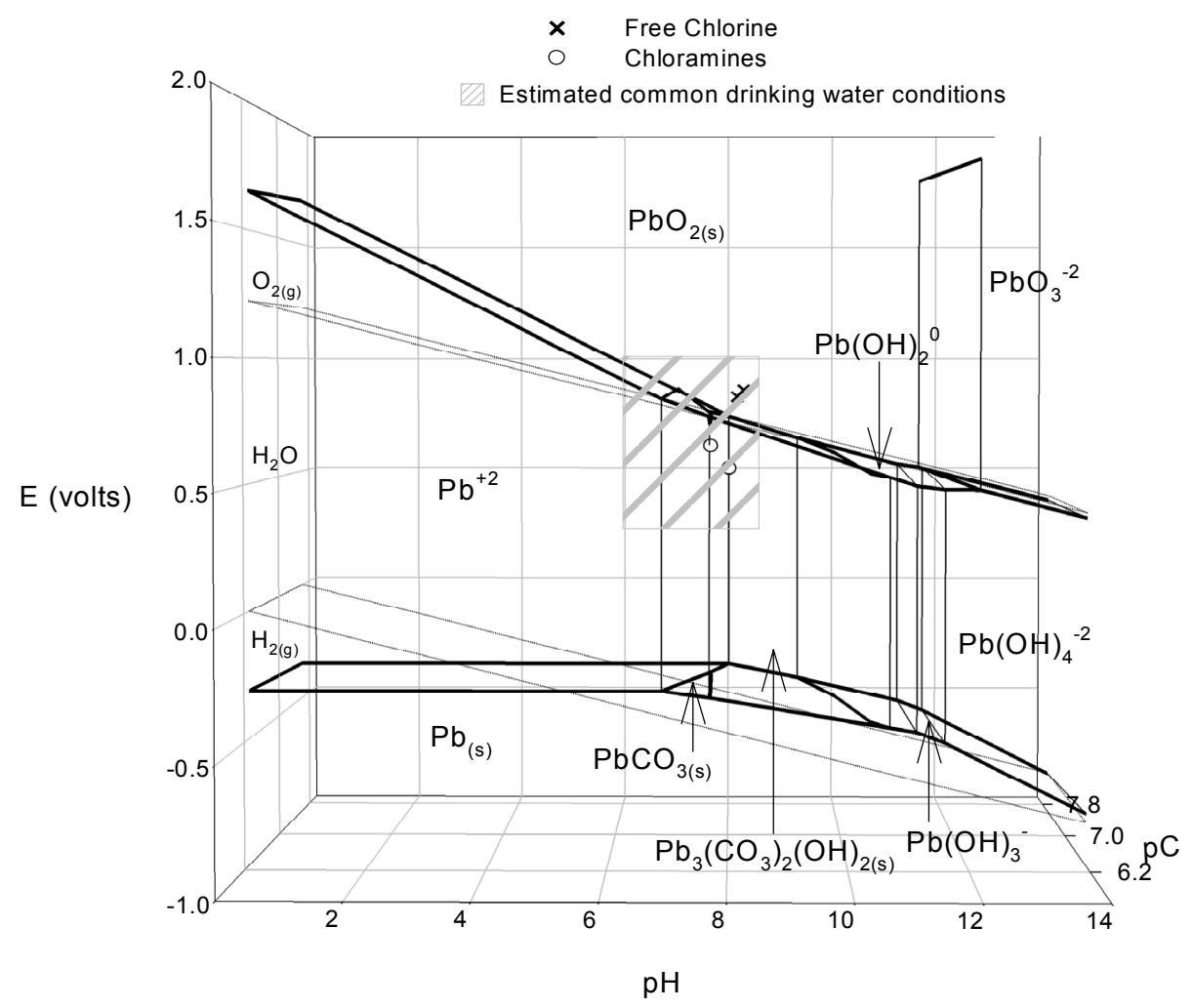

Figure 4.7 Lead potential versus $\mathrm{pH}$ and $\mathrm{pC}_{\mathrm{pb}}$ showing average total lead release and predominant lead species for desalinated water and surface water quality in field studies for free chlorine and chloramines. Alkalinity $=50 \mathrm{mg} / \mathrm{L} \mathrm{CaCO}$.

Investigators have stated that either cerussite or hydrocerussite can control solid phases for lead release to drinking water (Schock, 1989 \& 1990; Boffardi, 1995), and recently Shock has suggested that $\mathrm{PbO}_{2}$ is the controlling solid phase for lead release in the presence of free chlorine (Renner, 2004). X-ray photoelectron spectroscopy (XPS) surface characterization of lead coupons in the blending study revealed $\mathrm{PbO}_{2}, \mathrm{PbO}$, $\mathrm{PbCO}_{3}$ and $\mathrm{Pb}_{3}\left(\mathrm{CO}_{3}\right)_{2}(\mathrm{OH})_{2}$ solid phases (Tang, 2003 \& 2005); and associated $\mathrm{PbCO}_{3}$ negatively and $\mathrm{Pb}_{3}\left(\mathrm{CO}_{3}\right)_{2}(\mathrm{OH})_{2}$ positively with total lead release in the presence of chloramines. No association of $\mathrm{PbO}_{2}$ or $\mathrm{PbO}$ was found for the release of total lead in the presence of chloramines. Inclusion of the field data in the predominance diagrams clearly showed that hydrocerussite was the controlling solid phase because of the lower 
potential caused by chloramine residual maintenance in the PDSs, which resulted in higher total lead release relative to free chlorine. Conversely, the diagram also clearly showed that $\mathrm{PbO}_{2}$ was the controlling solid phase because of the higher potential caused by free chlorine residual maintenance in the PDSs, which resulted in lower total lead release relative to chloramines.

The significance of controlling solid films has been noted in the literature as these carbonate solid films may not adequately control lead release and may be disrupted and enhance soluble and particulate lead release due to changes in finished water quality (Leroy, 1993; Lytle, 1993 \& 2000; and Schock, 1999; 1990; \& 1989). $\mathrm{Pb}^{+4}$ release from $\mathrm{PbO}_{2}$ dissolution at $\mathrm{pH} 8$ and $25{ }^{\circ} \mathrm{C}$ is approximately $10^{-40} \mathrm{M}$ at equilibrium, and $\mathrm{Pb}^{+2}$ release is approximately $10^{-10} \mathrm{M}$ at equilibrium for cerussite or hydrocerussite at these same conditions for alkalinities of 50 to $200 \mathrm{mg} / \mathrm{L} \mathrm{CaCO}_{3}$. Although equilibrium is seldom achieved in drinking water, the predicted release of soluble lead from these two solids illustrates the benefits of $\mathrm{PbO}_{2}$ passivation. $\mathrm{PbO}_{2}$ has been shown to be predominant to cerussite or hydrocerussite in these studies in the presence of free chlorine, which significantly reduced total lead release.

Figure 4.8 was developed by Tang (2003) to illustrate the soluble lead released at equilibrium (the light plane) and the limitation of mass transfer by diffusion (the dark plane) on lead released from hydrocerussite for varying $\mathrm{pH}$ and alkalinity. As Figure 4.8 clearly shows, soluble lead release increases with increasing alkalinity and decreasing pH. Actual data from the literature was included in Figure 4.8 that shows the actual release of dissolved lead was accurately predicted by the hydrocerussite model (Schock, 1990). Tang clearly shows the limitations of diffusion on lead release in the field study. 
The lead surface area in the copper coils was simply not large enough to allow lead equilibrium to be achieved in the 6-8 holding periods prior to sample collections. The figure was modified to include total lead release in the presence of free chlorine (clear symbols) and chloramines (dark symbols) for the four different finished waters. As shown in Figure 4.8, the total lead release in the presence of chloramines is greater than the total lead release in the presence of chlorine. The variation in total lead release among sources was attributed to differences in source water quality and particulate release.

$\begin{array}{llll}\circ & \text { GW with Free chlorine } & \bullet & \text { GW with Chloramines } \\ \star & \text { SW with Free chlorine } & \star & \text { SW with Chloramines } \\ \square & \text { RO with Free chlorine } & \bullet & \text { RO with Chloramines } \\ \diamond & \text { BW with Free chlorine } & \bullet & \text { BW with Chloramines }\end{array}$

$\square$ Hydrocerussite Model

$\square$ Hydrocerussite Model Modified by Difussion

$\boldsymbol{\nabla}$ Schock's Experimental Data (Schock 1980)

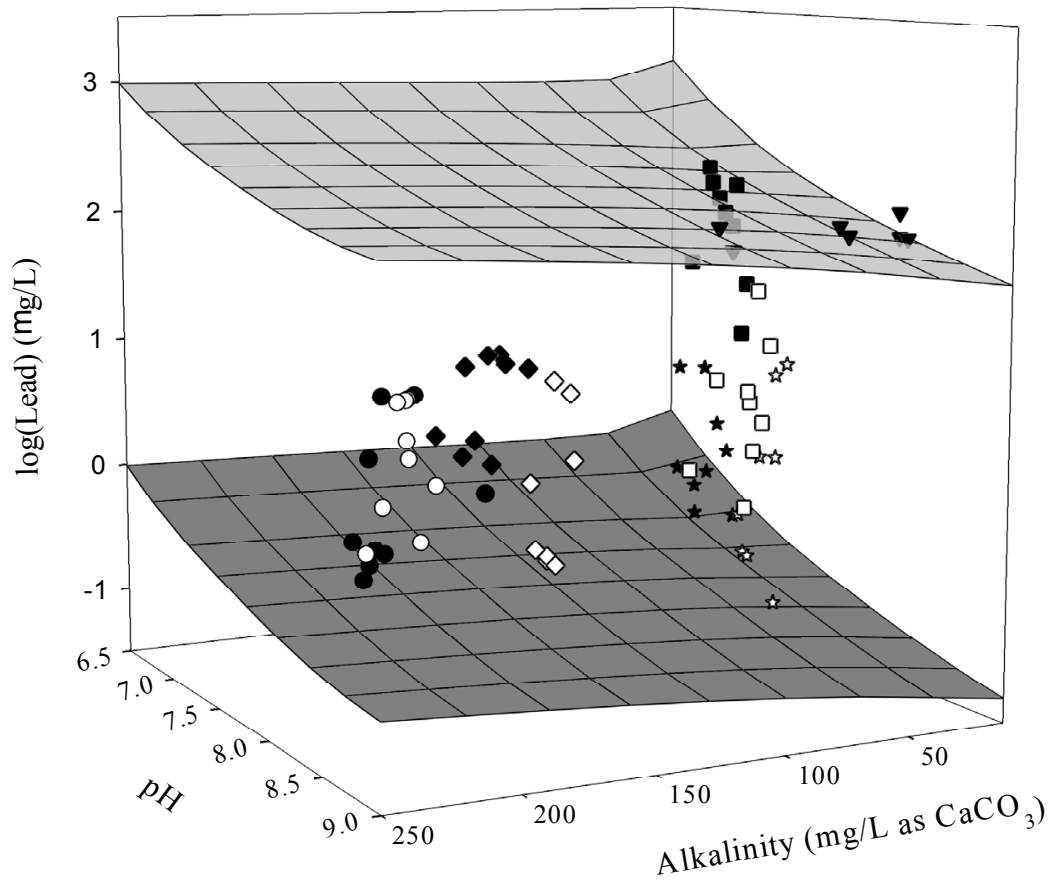

Figure 4.8 Log soluble lead species versus alkalinity and $\mathrm{pH}$ assuming cerussite and hydrocerussite controlling solid phases and actual data in the presence of free chlorine and chloramines and from Schock (1999) 


\section{CONCLUSIONS}

- There were no ORP differences among sources in the presence of chloramines or free chlorine. The addition of $150 \mathrm{mg} / \mathrm{L} \mathrm{of} \mathrm{SO}_{4}{ }^{-2}$ to finished SW or the addition of $106.5 \mathrm{mg} / \mathrm{L}$ of $\mathrm{Cl}^{-}$to finished RO did not significantly change the ORP in the presence of chloramines or free chlorine.

- ORP decreased with increasing temperature, which was consistent with the magnitude of the Equilibrium constant as affected by temperature

- Source ORP was greater in the presence of free chlorine than in the presence of chloramines. HPCs and biofilm densities in the presence of chloramines were significantly greater than in the presence of free chlorine for the field study. Differences among water qualities of the four finished waters (alkalinity, sulfates, chlorides, and nitrates) used in the field study did not account for the observed differences in total lead release in the presence of chloramines or free chlorine.

- Chloramine residual produced a lower ORP and a hydrocerrusite controlling solid phase, which released more average total lead relative to free chlorine.

Conversely, free chlorine produced a higher ORP and $\mathrm{PbO}^{2}$ controlling solid phase, which released less average total lead relative to chloramines. The predicted release of soluble lead from hydrocerussite was approximately $10^{-10} \mathrm{M}$ and the predicted release of soluble lead from $\mathrm{PbO}_{2}$ was approximately $10^{-40} \mathrm{M}$, which supported the relative orders of total lead release in the presence of chloramines and free chlorine.

- The controlling solid phase as effected by ORP can fundamentally explain the higher lead release in the presence of chloramines relative to free chlorine, but does not eliminate the possibility of increased total lead release with increasing biological activity in the presence of chloramines relative to free chlorine. 


\section{REFERENCES}

Abd El Rehim S. S. and Mohamed N. F. (1998). Passivity Breakdown of Lead Anode in Alkaline Nitrate Solutions. Corrosion Science. 40(11):1883-1896.

Amin M. A. and Abd El Rehim S. S. (2004). Pitting Corrosion of Lead in Sodium Carbonate Solutions Containing $\mathrm{NO}_{3}{ }^{-}$ions. Electrochemica Acta. 49(15):2415-2424.

Arevalo J., Taylor J., Dietz J., and Mutoti G. (2004). Modeling Chlorine Dissipation in Distribution Systems. Proceedings in 2004 AWWA Annual Conference, Orlando, Fl.

AWWARF-DVGW Forschungsstelle. (1985). Internal Corrosion of Water Distribution Systems. Denver: AWWA Research Foundation/DBGW-Forschungsstelle.

Bellinger D., Sloman J., Leviton A., Rabinowitz M., Needleman H. L., and Waternaux C. (1991). Low-level Lead Exposure and Children's Cognitive Function in the Preschool Years. Pediatrics. 87(2):219-227.

Boffardi B.P. (1988). Lead in Drinking Water - Causes and Cures. Public Works. 119(12):6770 .

Boffardi B.P. (1995). Lead Corrosion. Journal of the New England Water Works Association. 109(2):121-131.

Cantor A.F., Park J., and Vaiyavatjamai P. (2003). Effect of Chlorine on Corrosion in Drinking Water Systems. Journal of American Water Works Association. 95(5):112-123.

Cohn D. (2004). Lead in D.C. Water Slashed; Decline Comes After WASA Resumes Using Chlorine as Disinfectant. Washington Post. May 21.

Edwards M. and Dudi A. (2004). Role of Chlorine and Chloramine in Corrosion of Leadbearing Plumbing Materials. Journal of American Water Works Association. 96(10):69-81.

Fewtrell L. J., Pruss-Ustun A., Landrigan P., and Ayuso-Mateos J. L. (2004). Estimating the Global Burden of Disease of Mild Mental Retardation and Cardiovascular Diseases from Environmental Lead Exposure. Environmental Research. 94(2):120-133.

Gardels M. C. and Sorg T. J. (1989). A Laboratory Study of the Leaching of Lead from Water Faucets. Journal of American Water Works Association. 81(7):101-113. 
Haas D. (1999). Disinfection. Water Quality and Treatment, $5^{\text {th }}$ ed. New York: McGraw-Hill.

Hem, J. D. and W. H. Durum. (1973). Solubility and Occurrence of Lead in Surface Water. Journal of American Water Works Association. 65(8):562-568.

Holder E. H. (2004) Summary of Investigation Reported to the Board of Directors of the District of Columbia Water and Sewer Authority. http://www.washingtonpost.com/wpsrv/metro/specials/water/wasa071604.pdf (accessed March 17, 2005).

Laurent P. and Servais P. (1995). Fixed Bacterial Biomass Estimated by Potential Exoproteolytic Activity. Canadian Journal of Microbiology. 41(8):749-752.

Lee R. G., Becker W. C., and Collins D. W. (1989). Lead at the Tap: Sources and Control. Journal of American Water Works Association. 81(7):52-62.

Leonnig C. D. (2000). Ammonia to Be Used in Treating D.C, Va. Water. Washington Post. October 11.

Leroy P. (1993). Lead in drinking water - origins; solubility; treatment. Aqua. 42(4):233-238.

Lin N.H., Torrents A., Davis A. P., and Zeinali M. (1997). Lead Corrosion Control from Lead, Copper-Lead Solder, and Brass Coupons in Drinking Water Employing Free and Chloramines. Journal of Environmental Science and Health. A32(4):865-884.

Lytle D. A and Schock M. R. (2000). Impact of Stagnation Time on Metal Dissolution from Plumbing Materials in Drinking Water. Aqua. (49(5):243-257.

Lytle D. A., Schock M. R., Dues N. R., and Clark P. J. (1993). Investigating the Preferential Dissolution of Lead from Solder Particulates. Journal of American Water Works Association. 85(7):104-110.

Nakamura D. (2004). Water in D.C. Exceeds EPA Lead Limit; Random Tests Last Summer Found High Levels in 4,000 Homes throughout City. Washington Post. January 31.

Nakamura D. and Timberg C. (2004). Two Lead Readings Reach into Thousands; D.C. Households Get No Extra Warning. Washington Post. March 4.

Pourbaix M. (1966). Atlas of Electrochemical Equilibria. Oxford: Pergamon Press Ltd.

Renner R. (2004). Plumbing the Depths of D. C.'s Drinking Water Crisis. Journal of Environmental Science and Technology. 38(12):224A-227A.

Schock M. R. (1980). Response of Lead Solubility to Dissolved Carbonate in Drinking Water. Journal of American Water Works Association. 72(12):695-704. 
Schock M. R. (1981). Response of Lead Solubility to Dissolved Carbonate in Drinking Water. Journal of American Water Works Association. 73(3):36 (erratum).

Schock M. R. and Gardels M. C. (1983). Plumbosolvency Reduction by high $\mathrm{pH}$ and Low Carbonate - Solubility Relationships. Journal of American Water Works Association. 75(2):8791.

Schock M. R. (1989). Understanding Corrosion Control Strategies for Lead. Journal of American Water Works Association. 81(7):88-100.

Schock M. R. (1990). Causes of Temporal Variability of Lead in Domestic Plumbing Systems. Environmental Monitoring and Assessment. 15(1):59-82.

Schock M. R. (1999). Internal Corrosion and Deposition Control. Water Quality and Treatment, $5^{\text {th }}$ ed. New York: McGraw-Hill.

Singer P. and Reckhow D. (1999). Chemical Oxidation. Water Quality and Treatment, $5^{\text {th }}$ ed. McGraw-Hill, New York.

Snoeyink V.L., and Jenkins D. (1980). Water Chemistry. New York: John Wiley \& Sons.

Standard Methods for the Examination of Water and Wastewater, $199519^{\text {th }}$ edition. American Public Health Association/ American Water Works Association/ Water Environment Federation: Washington, D. C.

Stumm W. and Morgan J.J. (1981). Aquatic Chemistry, $2^{\text {nd }}$ ed. New York: John Wiley \& Sons.

Tang J., Hong S. K., Xiao W., and Taylor J. S. (2005). Effect of Varying Blends of Finished Ro, Surface and Ground Waters on Solid Lead Surfaces. In Press, Journal of Corrosion Science

Tang J. (2003). Effect of Source Water Blending on Iron and Lead Release: Thermodynamic and Statistical Modeling. Ph.D. Dissertation, University of Central Florida. Orlando, FL.

Taylor J. S. et al. (2005). Effects of blending on Distribution System Water Quality. Denver: AWWA Research Foundation/AWWA.

Treweek G.P., Glicker J., Chow B., and Sprinker M. (1985). Pilot Plant Simulation of Corrosion in Domestic Pipe Materials. Journal of American Water Works Association. 77(10):74-82.

Uchida M. and Okuwaki A. (1999). The Dissolution Behavior of Lead Plates in Aqueous Nitrate Solutions. Corrosion Science. 41(10):1977-1986.

United States Environmental Protection Agency (USEPA). (2004). Lead and Copper Rule: A Quick Reference Guide. http://www.epa.gov/safewater/lcrmr/pdfs/qrg_lcmr_ 2004.pdf (accessed March 15, 2005). 
USEPA. (1998). National Primary Drinking Water Regulations: Disinfection and Disinfection By- Products: Final Rule. Federal Register, 63:241:69389-69476.

Vinceti M., Rovesti S., Bergomi M., Calzolari E., Candela S., Campagna A., Milan M., and Vivoli G. (2001). Risk of birth defects in a population exposed to environmental lead pollution. The Science of the Total Environment. 278(1-3):23-30. 


\section{APPENDIX}


Table A.1 Field pH

\begin{tabular}{ccccccccc}
\hline \multirow{2}{*}{ Date } & PDS 1 & PDS 2 & PDS 3 & PDS 4 & PDS 5 & PDS 6 & PDS 7 & PDS 8 \\
& GW & SW & RO & B & GW & SW & RO & B \\
\hline $4 / 17 / 03$ & 8.00 & 8.10 & 8.34 & 8.08 & 7.87 & 7.92 & 8.20 & 7.95 \\
$4 / 24 / 03$ & 7.93 & 8.13 & 8.28 & 8.04 & 7.82 & 7.78 & 8.25 & 7.88 \\
$5 / 01 / 03$ & 8.04 & 8.25 & 8.34 & 8.15 & 7.92 & 8.02 & 8.18 & 7.95 \\
$5 / 8 / 2003$ & 8.04 & 8.13 & 8.30 & 8.07 & 7.82 & 7.86 & 8.09 & 7.87 \\
$5 / 15 / 03$ & 8.05 & 8.33 & 8.37 & 8.14 & 8.29 & 7.97 & 8.18 & 7.97 \\
$5 / 21 / 03$ & 8.05 & 8.09 & 8.23 & 8.08 & 7.77 & 7.69 & 7.96 & 7.87 \\
$5 / 29 / 03$ & 8.08 & 8.29 & 8.28 & 8.11 & 7.86 & 7.65 & 8.10 & 7.97 \\
$6 / 04 / 03$ & 8.03 & 8.06 & 8.07 & 8.07 & 7.81 & 7.55 & 7.88 & 7.90 \\
$6 / 11 / 03$ & 8.05 & 8.11 & 8.25 & 8.05 & 7.82 & 7.59 & 8.00 & 7.95 \\
$6 / 18 / 03$ & 8.03 & 8.34 & 8.30 & 8.07 & 7.68 & 7.53 & 7.90 & 7.82 \\
$6 / 22 / 03$ & 8.06 & 7.92 & 8.23 & 7.94 & 7.81 & 7.46 & 7.92 & 7.74 \\
$6 / 24 / 03$ & 7.99 & 8.09 & 8.26 & 8.16 & 7.74 & 7.76 & 7.95 & 7.86 \\
$6 / 26 / 03$ & 8.06 & 8.26 & 8.39 & 8.10 & 7.80 & 7.80 & 7.94 & 7.94 \\
$4 / 17 / 03$ & 8.00 & 8.10 & 8.34 & 8.08 & 7.87 & 7.92 & 8.20 & 7.95 \\
\hline
\end{tabular}


Table A.2 Field Lead Concentration

\begin{tabular}{ccccccccc}
\hline \multirow{2}{*}{ Date } & PDS 1 & PDS 2 & PDS 3 & PDS 4 & PDS 5 & PDS 6 & PDS 7 & PDS 8 \\
& GW & SW & RO & B & GW & SW & RO & B \\
\hline $04 / 25 / 03$ & 3.48 & 0.70 & 0.90 & 0.40 & 0.40 & 1.11 & 40.41 & 2.34 \\
$05 / 02 / 03$ & 2.83 & 2.05 & 2.50 & 0.41 & 0.57 & 0.61 & 105.66 & 11.27 \\
$05 / 09 / 03$ & 1.31 & 0.33 & 6.72 & 1.60 & 2.46 & 2.75 & 127.58 & 3.44 \\
$05 / 16 / 03$ & 1.76 & 2.13 & 4.10 & 2.34 & 1.80 & 1.84 & 16.72 & 10.25 \\
$05 / 23 / 03$ & 0.70 & 0.08 & 1.80 & 0.45 & 0.45 & 0.49 & 201.02 & 1.93 \\
$05 / 30 / 03$ & 7.58 & 0.16 & 5.45 & 0.53 & 0.33 & 0.78 & 201.23 & 13.48 \\
$06 / 06 / 03$ & 0.61 & 0.33 & 7.05 & 0.04 & 0.61 & -0.04 & 49.59 & 3.07 \\
$06 / 20 / 03$ & 7.58 & 10.41 & 36.60 & 6.89 & 6.07 & 6.07 & 254.51 & 10.16 \\
$06 / 27 / 03$ & 7.62 & 8.24 & 15.29 & 8.89 & 6.80 & 7.17 & 151.64 & 13.20 \\
\hline
\end{tabular}

Table A.3 Field Alkalinity Concentration

\begin{tabular}{ccccccccc}
\hline \multirow{2}{*}{ Date } & PDS 1 & PDS 2 & PDS 3 & PDS 4 & PDS 5 & PDS 6 & PDS 7 & PDS 8 \\
& GW & SW & RO & B & GW & SW & RO & B \\
\hline $4 / 17 / 03$ & 204 & 70 & 76 & 152 & 210 & 66 & 72 & 184 \\
$4 / 24 / 03$ & 194 & 70 & 76 & 144 & 204 & 64 & 74 & 170 \\
$5 / 01 / 03$ & 198 & 68 & 76 & 146 & 206 & 66 & 76 & 172 \\
$5 / 08 / 03$ & 208 & 66 & 76 & 152 & 204 & 64 & 74 & 180 \\
$5 / 15 / 03$ & 188 & 66 & 74 & 138 & 180 & 66 & 72 & 148 \\
$5 / 21 / 03$ & 194 & 64 & 96 & 146 & 196 & 64 & 72 & 158 \\
$5 / 29 / 03$ & 204 & 64 & 74 & 152 & 208 & 62 & 70 & 164 \\
$6 / 04 / 03$ & 214 & 64 & 76 & 156 & 210 & 64 & 76 & 166 \\
$6 / 11 / 03$ & 216 & 62 & 72 & 154 & 212 & 64 & 70 & 166 \\
$6 / 18 / 03$ & 198 & 62 & 72 & 136 & 180 & 62 & 70 & 150 \\
$6 / 22 / 03$ & 156 & 78 & 86 & 102 & 158 & 84 & 70 & 124 \\
$6 / 24 / 03$ & 185 & 68 & 76 & 142 & 188 & 76 & 70 & 142 \\
$6 / 26 / 03$ & 200 & 62 & 72 & 144 & 198 & 66 & 68 & 158 \\
$6 / 29 / 03$ & 204 & 70 & 76 & 152 & 210 & 66 & 72 & 184 \\
\hline
\end{tabular}


Table A.4 Field Temperature

\begin{tabular}{ccccccccc}
\hline Date & PDS 1 & PDS 2 & PDS 3 & PDS 4 & PDS 5 & PDS 6 & PDS 7 & PDS 8 \\
& GW & SW & RO & B & GW & SW & RO & B \\
\hline $4 / 25 / 03$ & 27.0 & 27.9 & 27.5 & 28.0 & 27.5 & 27.6 & 27.5 & 27.9 \\
$5 / 01 / 03$ & 22.0 & 22.0 & 22.0 & 22.0 & 22.0 & 22.0 & 22.0 & 22.0 \\
$5 / 05 / 03$ & 30.8 & 30.8 & 30.8 & 30.8 & 30.8 & 30.8 & 30.0 & 30.0 \\
$5 / 08 / 03$ & 30.2 & 30.2 & 30.2 & 30.2 & 30.2 & 30.2 & 29.8 & 29.8 \\
$5 / 12 / 03$ & 30.6 & 30.6 & 30.6 & 30.6 & 30.6 & 30.6 & 30.2 & 30.2 \\
$5 / 15 / 03$ & 33.0 & 33.0 & 33.0 & 33.0 & 33.0 & 33.0 & 33.0 & 33.0 \\
$5 / 27 / 03$ & 30.6 & 30.6 & 30.6 & 30.6 & 30.6 & 30.6 & 30.6 & 30.6 \\
$6 / 03 / 03$ & 26.2 & 26.2 & 26.2 & 26.2 & 26.2 & 26.2 & 26.2 & 26.2 \\
$6 / 04 / 03$ & 26.0 & 26.0 & 26.0 & 26.0 & 26.0 & 26.0 & 26.0 & 26.0 \\
$6 / 13 / 03$ & 30.1 & 30.1 & 30.1 & 30.1 & 30.1 & 30.1 & 30.1 & 30.1 \\
$6 / 17 / 03$ & 28.6 & 28.6 & 28.6 & 28.6 & 28.6 & 28.6 & 28.6 & 28.3 \\
$6 / 18 / 03$ & 25.5 & 25.5 & 25.5 & 25.5 & 25.5 & 25.5 & 25.4 & 25.4 \\
$6 / 19 / 03$ & 23.9 & 23.9 & 23.9 & 23.9 & 23.9 & 23.9 & 23.9 & 23.9 \\
$6 / 22 / 03$ & 24.4 & 24.7 & 24.4 & 25.1 & 24.2 & 24.2 & 24.9 & 24.4 \\
$6 / 24 / 03$ & 28.8 & 28.8 & 28.8 & 28.8 & 28.8 & 28.8 & 28.5 & 28.5 \\
$6 / 27 / 03$ & 29.7 & 29.7 & 29.7 & 29.7 & 29.7 & 29.7 & 29.7 & 29.0 \\
\hline
\end{tabular}


Table A.5 Field Sulfate Concentration

\begin{tabular}{ccccccccc}
\hline \multirow{2}{*}{ Date } & $\begin{array}{c}\text { PDS 1 } \\
\text { GW }\end{array}$ & $\begin{array}{c}\text { PDS 2 } \\
\text { SW }\end{array}$ & $\begin{array}{c}\text { PDS 3 } \\
\text { RO }\end{array}$ & $\begin{array}{c}\text { PDS 4 } \\
\text { B }\end{array}$ & PDS 5 & PDS 6 & PDS 7 & PDS 8 \\
\hline $04 / 18 / 03$ & 29.0 & 216.9 & 3.8 & 79.5 & 35.0 & 215.0 & 4.7 & 48.7 \\
$04 / 25 / 03$ & 4.8 & 208.8 & 4.0 & 61.7 & 21.9 & 206.8 & 4.8 & 47.6 \\
$05 / 02 / 03$ & 18.0 & 213.1 & 6.7 & 70.9 & 22.4 & 224.2 & 6.3 & 45.0 \\
$05 / 09 / 03$ & 22.8 & 224.5 & 4.1 & 74.9 & 22.9 & 225.2 & 4.6 & 47.4 \\
$05 / 16 / 03$ & 5.5 & 227.1 & 3.4 & 62.9 & 2.6 & 224.7 & 4.1 & 45.2 \\
$05 / 23 / 03$ & 21.1 & 217.7 & 3.6 & 74.5 & 25.3 & 212.2 & 3.6 & 55.3 \\
$05 / 30 / 03$ & 28.1 & 227.1 & 4.1 & 81.8 & 28.0 & 221.6 & 3.9 & 58.9 \\
$06 / 06 / 03$ & 25.3 & 227.0 & 3.7 & 80.3 & 25.8 & 230.4 & 3.4 & 66.1 \\
$06 / 13 / 03$ & 26.0 & 231.3 & 3.1 & 83.7 & 26.5 & 225.2 & 3.2 & 60.5 \\
$06 / 20 / 03$ & 6.3 & 228.2 & 3.0 & 82.0 & 28.6 & 262.4 & 3.8 & 62.9 \\
$06 / 27 / 03$ & 28.0 & 227.8 & 3.4 & 85.7 & 29.6 & 234.1 & 5.9 & 68.3 \\
\hline
\end{tabular}

Table A.6 Field PEPA

\begin{tabular}{cccccccccc}
\hline \multirow{2}{*}{ Date } & \multirow{2}{*}{ Material } & $\begin{array}{c}\text { PDS 1 } \\
\text { GW }\end{array}$ & $\begin{array}{c}\text { PDS 2 } \\
\text { SW }\end{array}$ & $\begin{array}{c}\text { PDS 3 } \\
\text { RO }\end{array}$ & $\begin{array}{c}\text { PDS 4 } \\
\text { B }\end{array}$ & $\begin{array}{c}\text { PDS 5 } \\
\text { GW }\end{array}$ & $\begin{array}{c}\text { PDS 6 } \\
\text { SW }\end{array}$ & $\begin{array}{c}\text { PDS 7 } \\
\text { RO }\end{array}$ & $\begin{array}{c}\text { PDS } 8 \\
\text { B }\end{array}$ \\
\hline $6 / 26 / 03$ & PVC & $2.2 \mathrm{E}+08$ & $1.5 \mathrm{E}+09$ & $5.0 \mathrm{E}+08$ & $2.2 \mathrm{E}+08$ & $4.7 \mathrm{E}+09$ & $1.2 \mathrm{E}+09$ & $7.0 \mathrm{E}+08$ & $4.3 \mathrm{E}+09$ \\
$6 / 26 / 03$ & CICL & $3.5 \mathrm{E}+09$ & $5.5 \mathrm{E}+08$ & $1.2 \mathrm{E}+09$ & $9.2 \mathrm{E}+08$ & $5.6 \mathrm{E}+09$ & $4.5 \mathrm{E}+09$ & $7.5 \mathrm{E}+08$ & $2.8 \mathrm{E}+09$ \\
$6 / 26 / 03$ & CI & $9.7 \mathrm{E}+08$ & $1.1 \mathrm{E}+09$ & $1.7 \mathrm{E}+08$ & $3.3 \mathrm{E}+08$ & $4.5 \mathrm{E}+09$ & $9.9 \mathrm{E}+08$ & $7.9 \mathrm{E}+08$ & $6.4 \mathrm{E}+09$ \\
$6 / 26 / 03$ & G & $1.2 \mathrm{E}+09$ & $1.6 \mathrm{E}+09$ & $5.6 \mathrm{E}+08$ & $3.1 \mathrm{E}+08$ & $1.4 \mathrm{E}+09$ & $1.5 \mathrm{E}+09$ & $7.1 \mathrm{E}+08$ & $4.2 \mathrm{E}+09$ \\
\hline
\end{tabular}


Table A.7 Field Chloride Concentration

\begin{tabular}{ccccccccc}
\hline \multirow{2}{*}{ Date } & PDS 1 & PDS 2 & PDS 3 & PDS 4 & PDS 5 & PDS 6 & PDS 7 & PDS 8 \\
& GW & SW & RO & B & GW & SW & RO & B \\
\hline $04 / 18 / 03$ & 22.9 & 23.5 & 80.9 & 29.5 & 24.0 & 26.2 & 85.9 & 30.5 \\
$04 / 25 / 03$ & 17.4 & 23.5 & 85.6 & 27.9 & 22.6 & 29.6 & 91.6 & 31.1 \\
$05 / 02 / 03$ & 17.5 & 24.6 & 51.4 & 23.6 & 20.4 & 29.3 & 56.9 & 24.7 \\
$05 / 09 / 03$ & 18.1 & 26.5 & 76.3 & 28.0 & 21.7 & 29.1 & 82.9 & 28.4 \\
$05 / 16 / 03$ & 18.9 & 25.4 & 71.6 & 27.2 & 21.4 & 32.1 & 79.8 & 31.3 \\
$05 / 23 / 03$ & 19.1 & 25.8 & 72.7 & 27.3 & 23.2 & 30.7 & 78.7 & 31.0 \\
$05 / 30 / 03$ & 23.1 & 26.6 & 79.2 & 31.9 & 25.6 & 31.9 & 87.2 & 34.2 \\
$06 / 06 / 03$ & 23.1 & 28.9 & 79.2 & 32.5 & 27.3 & 34.9 & 87.4 & 36.1 \\
$06 / 13 / 03$ & 19.2 & 25.9 & 78.6 & 28.8 & 26.1 & 35.1 & 86.7 & 35.5 \\
$06 / 20 / 03$ & 19.5 & 27.2 & 76.3 & 31.2 & 26.4 & 33.7 & 82.7 & 35.5 \\
$06 / 27 / 03$ & 21.0 & 28.1 & 76.8 & 29.8 & 23.3 & 31.5 & 82.4 & 33.9 \\
\hline
\end{tabular}

Table A.8 Field Chlorine Residual Concentration

\begin{tabular}{ccccccccc}
\hline Date & PDS 1 & PDS 2 & PDS 3 & PDS 4 & PDS 5 & PDS 6 & PDS 7 & PDS 8 \\
& GW & SW & RO & B & GW & SW & RO & B \\
\hline $4 / 24 / 03$ & 1.29 & 1.81 & 3.32 & 1.82 & 0.44 & 1.05 & 0.59 & 2.46 \\
$5 / 01 / 03$ & 0.87 & 1.02 & 2.50 & 1.65 & 0.74 & 0.49 & 0.91 & 1.41 \\
$5 / 08 / 03$ & 0.25 & 1.29 & 2.42 & 1.11 & 0.26 & 0.31 & 0.39 & 0.54 \\
$5 / 15 / 03$ & 0.66 & 0.92 & 2.08 & 1.35 & 0.27 & 0.83 & 0.56 & 0.76 \\
$5 / 21 / 03$ & 0.61 & 1.08 & 3.06 & 1.05 & 0.22 & 0.10 & 0.56 & 0.70 \\
$5 / 29 / 03$ & 0.76 & 1.20 & 2.08 & 1.38 & 0.25 & 0.20 & 0.71 & 0.52 \\
$6 / 04 / 03$ & 0.58 & 1.26 & 1.62 & 1.40 & 0.15 & 0.44 & 0.62 & 0.54 \\
$6 / 11 / 03$ & 0.56 & 1.18 & 1.85 & 1.11 & 0.19 & 0.23 & 0.54 & 0.66 \\
$6 / 18 / 03$ & 1.12 & 1.59 & 3.18 & 2.17 & 0.19 & 0.13 & 0.61 & 0.47 \\
$6 / 22 / 03$ & 1.15 & 0.66 & 2.60 & 1.96 & 0.28 & 0.36 & 0.57 & 0.67 \\
$6 / 24 / 03$ & 1.18 & 1.30 & 3.18 & 2.44 & 0.28 & 0.24 & 0.47 & 0.70 \\
$6 / 26 / 03$ & 1.05 & 1.21 & 3.20 & 1.62 & 0.44 & 1.05 & 0.59 & 2.46 \\
\hline
\end{tabular}


Table A.9 Field NOx-N Concentration

\begin{tabular}{ccccccccc}
\hline \multirow{2}{*}{ Date } & $\begin{array}{c}\text { PDS 1 } \\
\text { GW }\end{array}$ & $\begin{array}{c}\text { PDS 2 } \\
\text { SW }\end{array}$ & $\begin{array}{c}\text { PDS 3 } \\
\text { RO }\end{array}$ & $\begin{array}{c}\text { PDS 4 } \\
\text { B }\end{array}$ & $\begin{array}{c}\text { PDS 5 } \\
\text { GW }\end{array}$ & $\begin{array}{c}\text { PDS 6 } \\
\text { SW }\end{array}$ & $\begin{array}{c}\text { PDS 7 } \\
\text { RO }\end{array}$ & $\begin{array}{c}\text { PDS 8 } \\
\text { B }\end{array}$ \\
\hline $5 / 02 / 03$ & 0.02 & 0.12 & 0.02 & 0.03 & 0.13 & 0.28 & 0.06 & 0.08 \\
$5 / 09 / 03$ & 0.03 & 0.19 & 0.03 & 0.05 & 0.31 & 0.46 & 0.11 & 0.16 \\
$5 / 16 / 03$ & 0.02 & 0.19 & 0.02 & 0.04 & 0.30 & 0.51 & 0.26 & 0.16 \\
\hline
\end{tabular}

Table A.10 Field Ammonia Concentration

\begin{tabular}{ccccccccc}
\hline Date & $\begin{array}{c}\text { PDS 1 } \\
\text { GW }\end{array}$ & $\begin{array}{c}\text { PDS 2 } \\
\text { SW }\end{array}$ & $\begin{array}{c}\text { PDS 3 } \\
\text { RO }\end{array}$ & $\begin{array}{c}\text { PDS 4 } \\
\text { B }\end{array}$ & $\begin{array}{c}\text { PDS 5 } \\
\text { GW }\end{array}$ & $\begin{array}{c}\text { PDS 6 } \\
\text { SW }\end{array}$ & $\begin{array}{c}\text { PDS 7 } \\
\text { RO }\end{array}$ & $\begin{array}{c}\text { PDS 8 } \\
\text { B }\end{array}$ \\
\hline $5 / 01 / 03$ & 0.01 & 0.01 & 0.00 & 0.00 & 0.43 & 0.60 & 0.47 & 0.43 \\
$5 / 09 / 03$ & 0.02 & 0.01 & 0.01 & 0.01 & 0.48 & 0.51 & 0.58 & 0.56 \\
$5 / 15 / 03$ & 0.01 & 0.01 & 0.01 & 0.00 & 0.45 & 0.25 & 0.57 & 0.58 \\
$5 / 16 / 03$ & 0.01 & 0.01 & 0.01 & 0.01 & 0.53 & 0.30 & 0.67 & 0.68 \\
\hline
\end{tabular}

Table A.11 Field HPC

\begin{tabular}{ccccccccc}
\hline Date & $\begin{array}{c}\text { PDS 1 } \\
\text { GW }\end{array}$ & $\begin{array}{c}\text { PDS 2 } \\
\text { SW }\end{array}$ & $\begin{array}{c}\text { PDS 3 } \\
\text { RO }\end{array}$ & $\begin{array}{c}\text { PDS 4 } \\
\text { B }\end{array}$ & $\begin{array}{c}\text { PDS } 5 \\
\text { GW }\end{array}$ & $\begin{array}{c}\text { PDS 6 } \\
\text { SW }\end{array}$ & $\begin{array}{c}\text { PDS } 7 \\
\text { RO }\end{array}$ & $\begin{array}{c}\text { PDS } 8 \\
\text { B }\end{array}$ \\
\hline $4 / 17 / 03$ & $1.3 \mathrm{E}+04$ & $2.2 \mathrm{E}+04$ & $8.2 \mathrm{E}+02$ & $3.7 \mathrm{E}+05$ & $4.6 \mathrm{E}+05$ & $8.3 \mathrm{E}+03$ & $2.7 \mathrm{E}+04$ & $1.3 \mathrm{E}+04$ \\
$5 / 01 / 03$ & $4.6 \mathrm{E}+05$ & $7.0 \mathrm{E}+05$ & $2.5 \mathrm{E}+05$ & $4.3 \mathrm{E}+05$ & $9.5 \mathrm{E}+02$ & $2.5 \mathrm{E}+02$ & $4.2 \mathrm{E}+05$ & $9.1 \mathrm{E}+03$ \\
$5 / 08 / 03$ & $3.3 \mathrm{E}+03$ & $1.0 \mathrm{E}+02$ & $5.0 \mathrm{E}+02$ & $3.5 \mathrm{E}+02$ & $1.4 \mathrm{E}+04$ & $9.9 \mathrm{E}+03$ & $1.1 \mathrm{E}+04$ & $2.3 \mathrm{E}+03$ \\
$5 / 15 / 03$ & $4.6 \mathrm{E}+04$ & $5.0 \mathrm{E}+01$ & $1.2 \mathrm{E}+06$ & $3.0 \mathrm{E}+02$ & $6.8 \mathrm{E}+03$ & $6.0 \mathrm{E}+02$ & $2.2 \mathrm{E}+03$ & $1.6 \mathrm{E}+03$ \\
$5 / 22 / 03$ & $2.4 \mathrm{E}+04$ & $1.5 \mathrm{E}+04$ & $6.0 \mathrm{E}+05$ & $1.8 \mathrm{E}+02$ & $6.2 \mathrm{E}+03$ & $6.9 \mathrm{E}+03$ & $2.1 \mathrm{E}+03$ & $1.2 \mathrm{E}+03$ \\
$5 / 29 / 03$ & $7.0 \mathrm{E}+02$ & $2.5 \mathrm{E}+02$ & $5.0 \mathrm{E}+01$ & $5.0 \mathrm{E}+01$ & $7.0 \mathrm{E}+03$ & $1.3 \mathrm{E}+04$ & $2.1 \mathrm{E}+03$ & $1.1 \mathrm{E}+03$ \\
$6 / 05 / 03$ & $1.3 \mathrm{E}+03$ & $2.0 \mathrm{E}+02$ & $4.8 \mathrm{E}+04$ & $1.0 \mathrm{E}+02$ & $2.9 \mathrm{E}+05$ & $9.5 \mathrm{E}+02$ & $2.0 \mathrm{E}+03$ & $7.5 \mathrm{E}+02$ \\
$6 / 12 / 03$ & $7.5 \mathrm{E}+02$ & $2.5 \mathrm{E}+03$ & $5.5 \mathrm{E}+02$ & $5.0 \mathrm{E}+01$ & $3.3 \mathrm{E}+03$ & $3.6 \mathrm{E}+03$ & $5.0 \mathrm{E}+02$ & $1.3 \mathrm{E}+03$ \\
$6 / 19 / 03$ & $9.0 \mathrm{E}+02$ & $5.5 \mathrm{E}+02$ & $3.5 \mathrm{E}+02$ & $1.0 \mathrm{E}+02$ & $6.0 \mathrm{E}+03$ & $5.4 \mathrm{E}+03$ & $2.7 \mathrm{E}+03$ & $3.3 \mathrm{E}+03$ \\
$6 / 25 / 03$ & $1.8 \mathrm{E}+02$ & $2.7 \mathrm{E}+02$ & $1.5 \mathrm{E}+01$ & $1.1 \mathrm{E}+02$ & $1.0 \mathrm{E}+04$ & $1.1 \mathrm{E}+04$ & $5.3 \mathrm{E}+03$ & $3.1 \mathrm{E}+03$ \\
$6 / 26 / 03$ & $6.7 \mathrm{E}+02$ & $4.4 \mathrm{E}+02$ & $5.9 \mathrm{E}+02$ & $2.7 \mathrm{E}+02$ & $7.7 \mathrm{E}+03$ & $8.0 \mathrm{E}+03$ & $2.3 \mathrm{E}+03$ & $3.0 \mathrm{E}+03$ \\
$6 / 27 / 03$ & $4.5 \mathrm{E}+02$ & $3.2 \mathrm{E}+02$ & $3.0 \mathrm{E}+01$ & $3.9 \mathrm{E}+02$ & $6.4 \mathrm{E}+03$ & $2.7 \mathrm{E}+03$ & $1.5 \mathrm{E}+03$ & $1.4 \mathrm{E}+03$ \\
\hline
\end{tabular}


Table A. 12 ORP Titration of GW at 5C using Free Chlorine

\begin{tabular}{|c|c|c|c|}
\hline Temperature ${ }^{\circ} \mathrm{C}$ & $\mathrm{pH}$ & Volts (SHE) & $\mathrm{mg} / \mathrm{L} \mathrm{Cl}_{2}$ added \\
\hline 5.1 & 7.46 & 0.566 & 0.00 \\
\hline 4.9 & 7.48 & 0.567 & 0.01 \\
\hline 4.6 & 7.47 & 0.569 & 0.03 \\
\hline 4.5 & 7.48 & 0.570 & 0.04 \\
\hline 4.2 & 7.49 & 0.575 & 0.05 \\
\hline 4.0 & 7.49 & 0.582 & 0.07 \\
\hline 3.8 & 7.49 & 0.589 & 0.09 \\
\hline 3.7 & 7.49 & 0.598 & 0.11 \\
\hline 3.6 & 7.49 & 0.605 & 0.12 \\
\hline 3.6 & 7.49 & 0.612 & 0.13 \\
\hline 3.5 & 7.50 & 0.616 & 0.15 \\
\hline 3.5 & 7.50 & 0.625 & 0.16 \\
\hline 3.4 & 7.50 & 0.629 & 0.18 \\
\hline 3.4 & 7.53 & 0.638 & 0.20 \\
\hline 3.4 & 7.54 & 0.645 & 0.22 \\
\hline 3.4 & 7.53 & 0.651 & 0.25 \\
\hline 3.5 & 7.54 & 0.658 & 0.27 \\
\hline 3.5 & 7.55 & 0.664 & 0.29 \\
\hline 3.6 & 7.56 & 0.667 & 0.30 \\
\hline 3.6 & 7.55 & 0.678 & 0.33 \\
\hline 3.6 & 7.56 & 0.678 & 0.35 \\
\hline 3.7 & 7.56 & 0.688 & 0.38 \\
\hline 3.8 & 7.56 & 0.698 & 0.41 \\
\hline 3.8 & 7.56 & 0.704 & 0.44 \\
\hline 3.9 & 7.56 & 0.71 & 0.48 \\
\hline 4.0 & 7.55 & 0.721 & 0.52 \\
\hline 4.1 & 7.57 & 0.73 & 0.56 \\
\hline 4.1 & 7.56 & 0.749 & 0.61 \\
\hline 4.2 & 7.57 & 0.759 & 0.65 \\
\hline 4.3 & 7.57 & 0.769 & 0.69 \\
\hline 4.3 & 7.57 & 0.78 & 0.73 \\
\hline 4.4 & 7.58 & 0.794 & 0.79 \\
\hline 4.5 & 7.58 & 0.806 & 0.83 \\
\hline 4.5 & 7.58 & 0.806 & 0.83 \\
\hline 4.6 & 7.60 & 0.858 & 1.19 \\
\hline 4.6 & 7.61 & 0.879 & 1.56 \\
\hline 4.7 & 7.61 & 0.898 & 1.92 \\
\hline 4.7 & 7.61 & 0.91 & 2.28 \\
\hline 4.8 & 7.63 & 0.925 & 3.01 \\
\hline 4.9 & 7.65 & 0.943 & 4.10 \\
\hline 4.9 & 7.66 & 0.962 & 5.55 \\
\hline 5.0 & 7.69 & 0.983 & 7.37 \\
\hline 5.1 & 7.71 & 0.995 & 9.55 \\
\hline 52 & 772 & عهمـ & 1064 \\
\hline
\end{tabular}


Table A.13 ORP Titration of GW at 10C using Free Chlorine

\begin{tabular}{|c|c|c|c|}
\hline Temperature ${ }^{\circ} \mathrm{C}$ & $\mathrm{pH}$ & Volts (SHE) & $\mathrm{mg} / \mathrm{L} \mathrm{Cl}_{2}$ added \\
\hline 10.9 & 7.60 & 0.707 & 0.00 \\
\hline 10.6 & 7.62 & 0.704 & 0.01 \\
\hline 10.3 & 7.62 & 0.699 & 0.03 \\
\hline 10.0 & 7.62 & 0.699 & 0.04 \\
\hline 9.8 & 7.63 & 0.696 & 0.06 \\
\hline 9.5 & 7.63 & 0.696 & 0.08 \\
\hline 9.2 & 7.63 & 0.696 & 0.11 \\
\hline 9.0 & 7.63 & 0.697 & 0.13 \\
\hline 8.8 & 7.64 & 0.697 & 0.16 \\
\hline 8.7 & 7.64 & 0.697 & 0.19 \\
\hline 8.6 & 7.65 & 0.698 & 0.21 \\
\hline 8.5 & 7.66 & 0.698 & 0.23 \\
\hline 8.3 & 7.67 & 0.698 & 0.26 \\
\hline 8.3 & 7.68 & 0.699 & 0.30 \\
\hline 8.3 & 7.67 & 0.702 & 0.34 \\
\hline 8.4 & 7.65 & 0.703 & 0.37 \\
\hline 8.4 & 7.66 & 0.705 & 0.40 \\
\hline 8.4 & 7.67 & 0.705 & 0.43 \\
\hline 8.5 & 7.67 & 0.708 & 0.47 \\
\hline 8.6 & 7.68 & 0.710 & 0.52 \\
\hline 8.7 & 7.70 & 0.710 & 0.55 \\
\hline 8.8 & 7.69 & 0.713 & 0.59 \\
\hline 9.1 & 7.71 & 0.713 & 0.63 \\
\hline 9.2 & 7.70 & 0.714 & 0.68 \\
\hline 9.2 & 7.70 & 0.720 & 0.71 \\
\hline 9.2 & 7.71 & 0.722 & 0.75 \\
\hline 9.2 & 7.71 & 0.735 & 0.80 \\
\hline 9.1 & 7.72 & 0.739 & 0.83 \\
\hline 9.0 & 7.72 & 0.742 & 0.86 \\
\hline 8.9 & 7.72 & 0.753 & 0.90 \\
\hline 8.8 & 7.72 & 0.757 & 0.93 \\
\hline 8.7 & 7.72 & 0.761 & 0.95 \\
\hline 8.7 & 7.73 & 0.766 & 0.98 \\
\hline 8.7 & 7.73 & 0.771 & 1.01 \\
\hline 8.8 & 7.74 & 0.776 & 1.04 \\
\hline 8.9 & 7.74 & 0.792 & 1.11 \\
\hline 9.1 & 7.71 & 0.807 & 1.16 \\
\hline 9.2 & 7.73 & 0.814 & 1.21 \\
\hline 9.4 & 7.72 & 0.819 & 1.27 \\
\hline 9.5 & 7.71 & 0.819 & 1.27 \\
\hline 9.6 & 7.73 & 0.860 & 1.93 \\
\hline 10.0 & 7.73 & 0.885 & 2.27 \\
\hline 10.1 & 7.74 & 0.905 & 2.60 \\
\hline 10.0 & 7.75 & 0.915 & 2.93 \\
\hline
\end{tabular}


ORP Titration of GW at $10 \mathrm{C}$ using Free Chlorine (continued)

\begin{tabular}{cccc}
\hline Temperature ${ }^{\circ} \mathrm{C}$ & $\mathrm{pH}$ & Volts $(\mathrm{SHE})$ & $\mathrm{mg} / \mathrm{L} \mathrm{Cl}_{2}$ added \\
\hline 9.9 & 7.75 & 0.927 & 3.60 \\
9.8 & 7.75 & 0.942 & 3.93 \\
9.6 & 7.76 & 0.958 & 4.60 \\
9.5 & 7.77 & 0.980 & 5.93 \\
9.5 & 7.79 & 0.992 & 6.93 \\
9.6 & 7.81 & 1.002 & 8.60 \\
9.7 & 7.82 & 1.010 & 10.27 \\
9.7 & 7.84 & 1.014 & 11.60 \\
10.0 & 7.84 & 1.018 & 12.27 \\
\hline
\end{tabular}


Table A.14 ORP Titration of GW at 25C using Free Chlorine

\begin{tabular}{cccc}
\hline Temperature ${ }^{\circ} \mathrm{C}$ & $\mathrm{pH}$ & Volts $(\mathrm{SHE})$ & $\mathrm{mg} / \mathrm{L} \mathrm{Cl}_{2}$ added \\
\hline 2.1 .8 & 7.64 & 0.614 & 0.00 \\
21.9 & 7.64 & 0.612 & 0.01 \\
22.7 & 7.54 & 0.611 & 0.03 \\
22.8 & 7.56 & 0.612 & 0.05 \\
22.9 & 7.54 & 0.613 & 0.07 \\
22.9 & 7.55 & 0.615 & 0.08 \\
23.0 & 7.55 & 0.617 & 0.09 \\
23.0 & 7.56 & 0.620 & 0.11 \\
23.0 & 7.56 & 0.623 & 0.12 \\
23.1 & 7.58 & 0.627 & 0.13 \\
23.1 & 7.58 & 0.630 & 0.15 \\
23.1 & 7.58 & 0.633 & 0.16 \\
23.1 & 7.60 & 0.636 & 0.17 \\
23.1 & 7.60 & 0.640 & 0.19 \\
23.1 & 7.61 & 0.643 & 0.20 \\
23.1 & 7.62 & 0.646 & 0.21 \\
23.1 & 7.62 & 0.649 & 0.23 \\
23.1 & 7.62 & 0.654 & 0.25 \\
23.1 & 7.63 & 0.658 & 0.27 \\
23.1 & 7.63 & 0.661 & 0.29 \\
23.1 & 7.64 & 0.664 & 0.31 \\
23.1 & 7.65 & 0.668 & 0.33 \\
23.1 & 7.66 & 0.674 & 0.36 \\
23.1 & 7.66 & 0.677 & 0.38 \\
23.0 & 7.67 & 0.679 & 0.40 \\
23.0 & 7.68 & 0.683 & 0.43 \\
23.0 & 7.68 & 0.686 & 0.45 \\
23.0 & 7.68 & 0.687 & 0.48 \\
23.0 & 7.70 & 0.691 & 0.51 \\
22.9 & 7.71 & 0.695 & 0.54 \\
22.9 & 7.72 & 0.697 & 0.57 \\
22.9 & 7.72 & 0.697 & 0.57 \\
22.9 & 7.74 & 0.794 & 0.90 \\
22.9 & 7.75 & 0.834 & 1.22 \\
22.9 & 7.76 & 0.861 & 1.54 \\
22.9 & 7.77 & 0.879 & 1.86 \\
22.9 & 7.79 & 0.902 & 2.50 \\
22.8 & 7.80 & 0.927 & 3.79 \\
22.8 & 7.83 & 0.954 & 6.36 \\
22.9 & 7.85 & 0.975 & 8.29 \\
22.9 & 7.88 & 0.987 & \\
\hline & & & \\
\hline
\end{tabular}


Table A.15 ORP Titration of GW at 30C using Free Chlorine

\begin{tabular}{cccc}
\hline Temperature ${ }^{\circ} \mathrm{C}$ & $\mathrm{pH}$ & Volts $(\mathrm{SHE})$ & $\mathrm{mg} / \mathrm{L} \mathrm{Cl}_{2}$ added \\
\hline 39.9 & 7.67 & 0.460 & 0.00 \\
30.4 & 7.69 & 0.462 & 0.01 \\
30.9 & 7.70 & 0.464 & 0.03 \\
31.1 & 7.72 & 0.465 & 0.05 \\
31.4 & 7.72 & 0.466 & 0.07 \\
31.6 & 7.74 & 0.466 & 0.10 \\
31.7 & 7.75 & 0.468 & 0.12 \\
31.8 & 7.76 & 0.470 & 0.15 \\
32.0 & 7.76 & 0.475 & 0.17 \\
32.1 & 7.81 & 0.478 & 0.19 \\
32.1 & 7.82 & 0.480 & 0.21 \\
32.0 & 7.83 & 0.484 & 0.24 \\
31.9 & 7.84 & 0.486 & 0.27 \\
31.9 & 7.83 & 0.489 & 0.31 \\
31.8 & 7.83 & 0.495 & 0.35 \\
31.7 & 7.84 & 0.498 & 0.37 \\
31.6 & 7.84 & 0.505 & 0.41 \\
31.5 & 7.85 & 0.509 & 0.44 \\
31.4 & 7.86 & 0.519 & 0.49 \\
31.3 & 7.85 & 0.524 & 0.51 \\
31.2 & 7.85 & 0.529 & 0.55 \\
31.2 & 7.86 & 0.536 & 0.58 \\
31.0 & 7.86 & 0.547 & 0.63 \\
30.9 & 7.86 & 0.550 & 0.65 \\
30.8 & 7.87 & 0.556 & 0.67 \\
30.8 & 7.87 & 0.567 & 0.70 \\
30.5 & 7.88 & 0.582 & 0.75 \\
30.2 & 7.87 & 0.593 & 0.79 \\
30.1 & 7.88 & 0.604 & 0.83 \\
30.0 & 7.88 & 0.614 & 0.86 \\
29.8 & 7.89 & 0.620 & 0.88 \\
29.8 & 7.89 & 0.630 & 0.92 \\
29.6 & 7.89 & 0.638 & 0.95 \\
29.3 & 7.91 & 0.642 & 0.99 \\
29.3 & 7.91 & 0.655 & 1.05 \\
29.2 & 7.91 & 0.663 & 1.09 \\
29.2 & 7.92 & 0.671 & 1.13 \\
29.1 & 7.92 & 0.683 & 1.21 \\
29.1 & 7.92 & 0.690 & 1.27 \\
29.0 & 7.93 & 0.699 & 1.33 \\
29.0 & 7.93 & 0.699 & 1.33 \\
28.9 & 7.95 & 0.734 & 1.65 \\
28.9 & 7.97 & 0.751 & 1.97 \\
28.8 & 7.98 & 0.768 & 2.30 \\
\hline & & & \\
\hline
\end{tabular}


ORP Titration of GW at 30C using Free Chlorine (continued)

\begin{tabular}{cccc}
\hline Temperature ${ }^{\circ} \mathrm{C}$ & $\mathrm{pH}$ & Volts $(\mathrm{SHE})$ & $\mathrm{mg} / \mathrm{L} \mathrm{Cl}_{2}$ added \\
\hline 28.8 & 7.98 & 0.784 & 2.62 \\
29.0 & 7.99 & 0.803 & 2.94 \\
29.6 & 8.01 & 0.820 & 3.27 \\
30.4 & 8.03 & 0.830 & 3.91 \\
30.8 & 8.05 & 0.846 & 4.56 \\
31.2 & 8.07 & 0.860 & 5.21 \\
31.2 & 8.10 & 0.873 & 6.18 \\
31.1 & 8.12 & 0.877 & 7.47 \\
31.0 & 8.14 & 0.885 & 8.44 \\
31.0 & 8.15 & 0.890 & 9.41 \\
30.9 & 8.17 & 0.894 & 10.38 \\
30.9 & 8.18 & 0.900 & 11.03 \\
30.7 & 8.20 & 0.903 & 11.35 \\
30.7 & 8.21 & 0.905 & 11.67 \\
30.6 & 8.22 & 0.908 & 12.32 \\
\hline
\end{tabular}


Table A.16 ORP Titration of GW at 5C using Chloramine

\begin{tabular}{cccc}
\hline Temperature ${ }^{\circ} \mathrm{C}$ & $\mathrm{pH}$ & Volts $(\mathrm{SHE})$ & $\mathrm{mg} / \mathrm{L} \mathrm{Cl}_{2}$ added \\
\hline 6.6 & 8.03 & 0.611 & 0.00 \\
6.5 & 8.03 & 0.610 & 0.01 \\
6.4 & 8.03 & 0.609 & 0.01 \\
6.4 & 8.03 & 0.609 & 0.03 \\
6.3 & 8.03 & 0.610 & 0.04 \\
6.2 & 8.02 & 0.617 & 0.07 \\
5.8 & 8.02 & 0.621 & 0.08 \\
5.7 & 8.03 & 0.628 & 0.10 \\
5.4 & 8.03 & 0.633 & 0.12 \\
5.2 & 8.03 & 0.641 & 0.16 \\
4.9 & 8.03 & 0.649 & 0.20 \\
4.7 & 8.03 & 0.653 & 0.23 \\
4.5 & 8.03 & 0.656 & 0.27 \\
4.5 & 8.03 & 0.661 & 0.32 \\
4.3 & 8.03 & 0.661 & 0.32 \\
4.1 & 8.04 & 0.674 & 0.55 \\
3.9 & 8.04 & 0.688 & 1.24 \\
3.9 & 8.04 & 0.695 & 2.39 \\
3.8 & 8.04 & 0.697 & 3.77 \\
3.8 & 8.04 & 0.301 & 5.15 \\
3.8 & 8.04 & 0.700 & 6.99 \\
3.8 & 8.03 & 0.224 & 7.91 \\
3.8 & 8.03 & 0.701 & 9.29 \\
3.8 & 8.03 & 0.701 & 10.67 \\
3.8 & 8.03 & 0.701 & 11.59 \\
3.8 & 8.03 & 0.701 & 12.51 \\
\hline & & &
\end{tabular}


Table A.17 ORP Titration of GW at 10C using Chloramine

\begin{tabular}{cccc}
\hline Temperature ${ }^{\circ} \mathrm{C}$ & $\mathrm{pH}$ & Volts $(\mathrm{SHE})$ & $\mathrm{mg} / \mathrm{L} \mathrm{Cl}_{2}$ added \\
\hline 10.5 & 8.22 & 0.527 & 0.00 \\
10.4 & 8.21 & 0.534 & 0.01 \\
10.2 & 8.21 & 0.551 & 0.02 \\
10.0 & 8.21 & 0.562 & 0.02 \\
9.9 & 8.18 & 0.574 & 0.03 \\
10.0 & 8.18 & 0.582 & 0.04 \\
9.9 & 8.17 & 0.590 & 0.05 \\
9.9 & 8.17 & 0.595 & 0.06 \\
9.9 & 8.17 & 0.600 & 0.07 \\
9.9 & 8.16 & 0.604 & 0.07 \\
10.0 & 8.16 & 0.608 & 0.08 \\
10.1 & 8.16 & 0.615 & 0.10 \\
10.0 & 8.16 & 0.621 & 0.12 \\
9.9 & 8.16 & 0.625 & 0.13 \\
9.8 & 8.16 & 0.629 & 0.15 \\
9.7 & 8.16 & 0.633 & 0.17 \\
9.8 & 8.16 & 0.638 & 0.20 \\
9.9 & 8.15 & 0.642 & 0.23 \\
10.0 & 8.15 & 0.647 & 0.28 \\
10.1 & 8.15 & 0.650 & 0.33 \\
10.2 & 8.15 & 0.655 & 0.42 \\
10.4 & 8.15 & 0.659 & 0.50 \\
10.4 & 8.15 & 0.659 & 0.50 \\
10.6 & 8.15 & 0.665 & 0.67 \\
10.7 & 8.15 & 0.670 & 1.00 \\
10.8 & 8.15 & 0.674 & 1.50 \\
10.9 & 8.14 & 0.678 & 2.17 \\
10.9 & 8.14 & 0.680 & 2.83 \\
11.0 & 8.14 & 0.681 & 3.83 \\
11.0 & 8.13 & 0.682 & 5.17 \\
11.1 & 8.13 & 0.683 & 7.17 \\
11.1 & 8.12 & 0.683 & 9.50 \\
11.2 & 8.12 & 0.683 & 11.83 \\
\hline & & &
\end{tabular}


Table A.18 ORP Titration of GW at 25C using Chloramine

\begin{tabular}{|c|c|c|c|}
\hline Temperature ${ }^{\circ} \mathrm{C}$ & $\mathrm{pH}$ & Volts (SHE) & $\mathrm{mg} / \mathrm{L} \mathrm{Cl} \mathrm{Cl}_{2}$ added \\
\hline 24.7 & 8.07 & 0.517 & 0.00 \\
\hline 26.1 & 8.06 & 0.542 & 0.02 \\
\hline 25.5 & 8.06 & 0.557 & 0.03 \\
\hline 25.4 & 8.06 & 0.566 & 0.03 \\
\hline 25.4 & 8.07 & 0.574 & 0.04 \\
\hline 25.4 & 8.08 & 0.580 & 0.05 \\
\hline 25.5 & 8.09 & 0.590 & 0.07 \\
\hline 25.6 & 8.09 & 0.599 & 0.08 \\
\hline 25.6 & 8.10 & 0.608 & 0.11 \\
\hline 25.7 & 8.10 & 0.616 & 0.14 \\
\hline 25.7 & 8.11 & 0.623 & 0.18 \\
\hline 25.6 & 8.11 & 0.627 & 0.21 \\
\hline 25.5 & 8.12 & 0.631 & 0.24 \\
\hline 25.5 & 8.12 & 0.636 & 0.29 \\
\hline 25.4 & 8.13 & 0.642 & 0.38 \\
\hline 25.4 & 8.13 & 0.645 & 0.46 \\
\hline 25.4 & 8.14 & 0.645 & 0.46 \\
\hline 25.2 & 8.14 & 0.65 & 0.62 \\
\hline 25.1 & 8.14 & 0.652 & 0.79 \\
\hline 25.1 & 8.14 & 0.655 & 0.96 \\
\hline 25.1 & 8.14 & 0.658 & 1.29 \\
\hline 25.2 & 8.15 & 0.661 & 1.96 \\
\hline 25.2 & 8.14 & 0.664 & 2.96 \\
\hline 25.2 & 8.14 & 0.665 & 4.29 \\
\hline 25.3 & 8.13 & 0.665 & 5.96 \\
\hline 25.3 & 8.13 & 0.665 & 7.96 \\
\hline 25.3 & 8.12 & 0.665 & 10.29 \\
\hline 25.3 & 8.11 & 0.665 & 12.96 \\
\hline 25.4 & 8.10 & 0.665 & 13.63 \\
\hline
\end{tabular}


Table A.19 ORP Titration of GW at 30C using Chloramine

\begin{tabular}{cccc}
\hline Temperature ${ }^{\circ} \mathrm{C}$ & $\mathrm{pH}$ & Volts $(\mathrm{SHE})$ & $\mathrm{mg} / \mathrm{L} \mathrm{Cl}_{2}$ added \\
\hline 29.8 & 8.1 & 0.526 & 0.00 \\
30.2 & 8.13 & 0.531 & 0.01 \\
30.1 & 8.14 & 0.542 & 0.02 \\
30.0 & 8.15 & 0.556 & 0.03 \\
29.9 & 8.16 & 0.565 & 0.05 \\
30.2 & 8.18 & 0.571 & 0.06 \\
30.0 & 8.20 & 0.577 & 0.07 \\
29.9 & 8.20 & 0.581 & 0.07 \\
29.8 & 8.23 & 0.585 & 0.08 \\
29.9 & 8.22 & 0.589 & 0.09 \\
29.9 & 8.23 & 0.593 & 0.10 \\
29.8 & 8.24 & 0.599 & 0.12 \\
29.7 & 8.25 & 0.604 & 0.13 \\
29.7 & 8.25 & 0.609 & 0.15 \\
29.6 & 8.26 & 0.612 & 0.17 \\
29.7 & 8.25 & 0.615 & 0.19 \\
29.8 & 8.26 & 0.619 & 0.22 \\
29.9 & 8.26 & 0.624 & 0.25 \\
30.0 & 8.26 & 0.627 & 0.28 \\
30.0 & 8.27 & 0.633 & 0.33 \\
29.9 & 8.27 & 0.637 & 0.42 \\
29.8 & 8.27 & 0.642 & 0.52 \\
29.8 & 8.27 & 0.642 & 0.52 \\
29.7 & 8.28 & 0.647 & 0.68 \\
29.8 & 8.27 & 0.651 & 0.85 \\
29.9 & 8.27 & 0.653 & 1.02 \\
29.9 & 8.27 & 0.655 & 1.18 \\
29.9 & 8.28 & 0.657 & 1.52 \\
30.0 & 8.27 & 0.659 & 1.85 \\
30.0 & 8.27 & 0.661 & 2.52 \\
30.0 & 8.26 & 0.662 & 3.18 \\
29.9 & 8.26 & 0.663 & 4.18 \\
29.9 & 8.25 & 0.663 & 5.85 \\
29.8 & 8.23 & 0.663 & 7.52 \\
29.7 & 8.23 & 0.663 & 9.85 \\
29.6 & 8.22 & 0.664 & 12.52 \\
\hline & & &
\end{tabular}


Table A.20 ORP Titration of SW at 5C using Free Chlorine

\begin{tabular}{|c|c|c|c|}
\hline Temperature ${ }^{\circ} \mathrm{C}$ & $\mathrm{pH}$ & Volts (SHE) & $\mathrm{mg} / \mathrm{L} \mathrm{Cl}_{2}$ added \\
\hline 5.3 & 7.99 & 0.615 & 0.00 \\
\hline 5.2 & 7.99 & 0.617 & 0.01 \\
\hline 5.2 & 7.99 & 0.622 & 0.03 \\
\hline 5.1 & 7.99 & 0.626 & 0.03 \\
\hline 5.1 & 7.99 & 0.630 & 0.04 \\
\hline 5.1 & 7.99 & 0.633 & 0.05 \\
\hline 5.1 & 7.99 & 0.639 & 0.05 \\
\hline 5.0 & 7.98 & 0.646 & 0.06 \\
\hline 5.0 & 7.98 & 0.658 & 0.07 \\
\hline 4.9 & 7.98 & 0.666 & 0.07 \\
\hline 4.9 & 7.98 & 0.673 & 0.08 \\
\hline 4.8 & 7.98 & 0.680 & 0.08 \\
\hline 4.8 & 7.97 & 0.688 & 0.09 \\
\hline 4.8 & 7.97 & 0.696 & 0.10 \\
\hline 4.8 & 7.97 & 0.711 & 0.12 \\
\hline 4.8 & 7.97 & 0.718 & 0.12 \\
\hline 4.8 & 7.97 & 0.724 & 0.13 \\
\hline 4.9 & 7.96 & 0.733 & 0.14 \\
\hline 4.9 & 7.96 & 0.74 & 0.15 \\
\hline 4.9 & 7.97 & 0.746 & 0.16 \\
\hline 4.9 & 7.97 & 0.751 & 0.16 \\
\hline 5.0 & 7.96 & 0.757 & 0.17 \\
\hline 5.0 & 7.96 & 0.763 & 0.18 \\
\hline 5.1 & 7.96 & 0.768 & 0.18 \\
\hline 5.2 & 7.96 & 0.773 & 0.19 \\
\hline 5.3 & 7.96 & 0.779 & 0.20 \\
\hline 5.2 & 7.96 & 0.784 & 0.20 \\
\hline 5.0 & 7.96 & 0.789 & 0.21 \\
\hline 4.9 & 7.96 & 0.794 & 0.22 \\
\hline 4.8 & 7.96 & 0.798 & 0.22 \\
\hline 4.7 & 7.96 & 0.804 & 0.23 \\
\hline 4.9 & 7.95 & 0.812 & 0.24 \\
\hline 5.0 & 7.96 & 0.815 & 0.25 \\
\hline 5.0 & 7.96 & 0.820 & 0.26 \\
\hline 5.1 & 7.96 & 0.825 & 0.27 \\
\hline 5.1 & 7.96 & 0.831 & 0.29 \\
\hline 5.2 & 7.96 & 0.835 & 0.30 \\
\hline 5.1 & 7.96 & 0.839 & 0.32 \\
\hline 5.1 & 7.95 & 0.846 & 0.34 \\
\hline 4.9 & 7.95 & 0.855 & 0.36 \\
\hline 4.8 & 7.95 & 0.859 & 0.38 \\
\hline 4.7 & 7.95 & 0.864 & 0.41 \\
\hline 4.7 & 7.96 & 0.869 & 0.43 \\
\hline 4.8 & 7.96 & 0.873 & 0.46 \\
\hline
\end{tabular}


ORP Titration of SW at 5C using Free Chlorine (continued)

\begin{tabular}{cccc}
\hline Temperature ${ }^{\circ} \mathrm{C}$ & $\mathrm{pH}$ & Volts $(\mathrm{SHE})$ & $\mathrm{mg} / \mathrm{L} \mathrm{Cl}_{2}$ added \\
\hline 4.9 & 7.95 & 0.878 & 0.48 \\
4.9 & 7.95 & 0.878 & 0.48 \\
4.7 & 7.97 & 0.907 & 0.80 \\
4.7 & 7.99 & 0.920 & 1.12 \\
4.8 & 8.02 & 0.928 & 1.44 \\
4.8 & 8.02 & 0.938 & 1.76 \\
4.9 & 8.04 & 0.946 & 2.08 \\
5.0 & 8.04 & 0.952 & 2.39 \\
5.2 & 8.06 & 0.961 & 3.35 \\
5.3 & 8.09 & 0.969 & 4.30 \\
5.5 & 8.14 & 0.980 & 6.21 \\
5.6 & 8.18 & 0.986 & 8.12 \\
5.7 & 8.20 & 0.992 & 10.03 \\
\hline
\end{tabular}


Table A.21 ORP Titration of SW at $15 \mathrm{C}$ using Free Chlorine

\begin{tabular}{|c|c|c|c|}
\hline Temperature ${ }^{\circ} \mathrm{C}$ & $\mathrm{pH}$ & Volts (SHE) & $\mathrm{mg} / \mathrm{L} \mathrm{Cl}_{2}$ added \\
\hline 14.9 & 7.87 & 0.577 & 0.00 \\
\hline 15.3 & 7.88 & 0.576 & 0.01 \\
\hline 15.6 & 7.88 & 0.575 & 0.01 \\
\hline 15.4 & 7.88 & 0.574 & 0.02 \\
\hline 14.7 & 7.89 & 0.575 & 0.03 \\
\hline 14.0 & 7.89 & 0.575 & 0.03 \\
\hline 14.0 & 7.89 & 0.576 & 0.04 \\
\hline 14.0 & 7.88 & 0.577 & 0.05 \\
\hline 14.1 & 7.89 & 0.579 & 0.05 \\
\hline 14.2 & 7.89 & 0.581 & 0.06 \\
\hline 14.3 & 7.90 & 0.584 & 0.07 \\
\hline 14.6 & 7.90 & 0.588 & 0.07 \\
\hline 14.3 & 7.90 & 0.592 & 0.08 \\
\hline 14.1 & 7.90 & 0.596 & 0.08 \\
\hline 14.0 & 7.90 & 0.600 & 0.09 \\
\hline 13.9 & 7.89 & 0.607 & 0.10 \\
\hline 14.2 & 7.90 & 0.614 & 0.10 \\
\hline 14.3 & 7.90 & 0.621 & 0.11 \\
\hline 14.6 & 7.91 & 0.630 & 0.12 \\
\hline 14.9 & 7.91 & 0.638 & 0.12 \\
\hline 15.1 & 7.92 & 0.643 & 0.13 \\
\hline 15.3 & 7.91 & 0.649 & 0.14 \\
\hline 15.3 & 7.91 & 0.655 & 0.14 \\
\hline 15.4 & 7.91 & 0.662 & 0.15 \\
\hline 15.4 & 7.92 & 0.670 & 0.16 \\
\hline 15.5 & 7.92 & 0.683 & 0.17 \\
\hline 15.5 & 7.92 & 0.690 & 0.18 \\
\hline 15.2 & 7.93 & 0.696 & 0.18 \\
\hline 15.0 & 7.93 & 0.710 & 0.20 \\
\hline 14.5 & 7.94 & 0.717 & 0.20 \\
\hline 14.3 & 7.93 & 0.721 & 0.21 \\
\hline 14.1 & 7.93 & 0.726 & 0.22 \\
\hline 14.1 & 7.94 & 0.731 & 0.22 \\
\hline 14.2 & 7.94 & 0.736 & 0.23 \\
\hline 14.3 & 7.95 & 0.740 & 0.24 \\
\hline 14.4 & 7.94 & 0.744 & 0.24 \\
\hline 14.5 & 7.95 & 0.747 & 0.25 \\
\hline 14.6 & 7.95 & 0.754 & 0.26 \\
\hline 14.7 & 7.95 & 0.762 & 0.27 \\
\hline 14.9 & 7.95 & 0.767 & 0.29 \\
\hline 15.0 & 7.95 & 0.773 & 0.30 \\
\hline 15.1 & 7.96 & 0.778 & 0.31 \\
\hline 15.2 & 7.96 & 0.783 & 0.33 \\
\hline 15.3 & 7.97 & 0.787 & 0.34 \\
\hline
\end{tabular}


ORP Titration of SW at $15 \mathrm{C}$ using Free Chlorine (continued)

\begin{tabular}{cccc}
\hline Temperature ${ }^{\circ} \mathrm{C}$ & $\mathrm{pH}$ & Volts $(\mathrm{SHE})$ & $\mathrm{mg} / \mathrm{L} \mathrm{Cl}_{2}$ added \\
\hline 15.4 & 7.96 & 0.793 & 0.36 \\
15.5 & 7.96 & 0.797 & 0.38 \\
15.5 & 7.97 & 0.803 & 0.41 \\
15.4 & 7.96 & 0.810 & 0.44 \\
15.4 & 7.96 & 0.810 & 0.44 \\
14.5 & 7.99 & 0.858 & 1.07 \\
14.4 & 8.01 & 0.870 & 1.39 \\
14.4 & 8.01 & 0.884 & 1.71 \\
14.4 & 8.02 & 0.893 & 2.03 \\
14.6 & 8.03 & 0.901 & 2.35 \\
14.7 & 8.04 & 0.911 & 2.98 \\
14.7 & 8.05 & 0.919 & 3.94 \\
14.8 & 8.09 & 0.927 & 4.89 \\
14.9 & 8.13 & 0.932 & 6.17 \\
15.1 & 8.16 & 0.937 & 8.08 \\
15.1 & 8.19 & 0.942 & 10.31 \\
\hline
\end{tabular}


Table A.22 ORP Titration of SW at 25C using Free Chlorine

\begin{tabular}{cccc}
\hline Temperature ${ }^{\circ} \mathrm{C}$ & $\mathrm{pH}$ & Volts $(\mathrm{SHE})$ & $\mathrm{mg} / \mathrm{L} \mathrm{Cl}_{2}$ added \\
\hline 22.6 & 7.56 & 0.606 & 0.00 \\
22.6 & 7.58 & 0.605 & 0.01 \\
22.6 & 7.59 & 0.606 & 0.02 \\
22.6 & 7.59 & 0.608 & 0.04 \\
22.6 & 7.60 & 0.613 & 0.05 \\
22.6 & 7.60 & 0.614 & 0.05 \\
22.6 & 7.61 & 0.624 & 0.07 \\
22.6 & 7.62 & 0.632 & 0.08 \\
22.6 & 7.63 & 0.636 & 0.09 \\
22.6 & 7.64 & 0.639 & 0.09 \\
22.7 & 7.64 & 0.644 & 0.10 \\
22.7 & 7.65 & 0.656 & 0.11 \\
22.7 & 7.66 & 0.676 & 0.13 \\
22.7 & 7.67 & 0.686 & 0.14 \\
22.7 & 7.68 & 0.695 & 0.15 \\
22.7 & 7.68 & 0.703 & 0.16 \\
22.8 & 7.69 & 0.710 & 0.18 \\
22.8 & 7.70 & 0.718 & 0.19 \\
22.8 & 7.70 & 0.724 & 0.20 \\
22.9 & 7.71 & 0.73 & 0.21 \\
22.9 & 7.71 & 0.736 & 0.22 \\
22.9 & 7.71 & 0.743 & 0.24 \\
22.9 & 7.71 & 0.748 & 0.26 \\
23.0 & 7.72 & 0.757 & 0.28 \\
23.0 & 7.72 & 0.764 & 0.30 \\
23.0 & 7.71 & 0.772 & 0.34 \\
23.1 & 7.71 & 0.780 & 0.37 \\
23.1 & 7.72 & 0.789 & 0.44 \\
23.1 & 7.72 & 0.789 & 0.44 \\
23.2 & 7.72 & 0.825 & 0.78 \\
23.2 & 7.74 & 0.843 & 1.11 \\
23.3 & 7.75 & 0.855 & 1.44 \\
23.4 & 7.77 & 0.865 & 1.78 \\
23.4 & 7.79 & 0.873 & 2.11 \\
23.4 & 7.82 & 0.885 & 2.78 \\
23.5 & 7.88 & 0.905 & 6.11 \\
23.5 & 7.94 & 0.916 & 9.11 \\
23.5 & 7.99 & 0.923 & 12.11 \\
\hline & & &
\end{tabular}


Table A.23 ORP Titration of SW at 30C using Free Chlorine

\begin{tabular}{cccc}
\hline Temperature ${ }^{\circ} \mathrm{C}$ & $\mathrm{pH}$ & Volts $(\mathrm{SHE})$ & $\mathrm{mg} / \mathrm{L} \mathrm{Cl}_{2}$ added \\
\hline 298 & 778 & 0642 & 000 \\
29.7 & 7.77 & 0.635 & 0.01 \\
29.7 & 7.78 & 0.627 & 0.01 \\
29.8 & 7.79 & 0.622 & 0.02 \\
29.9 & 7.80 & 0.615 & 0.02 \\
29.8 & 7.80 & 0.616 & 0.04 \\
30.0 & 7.81 & 0.617 & 0.05 \\
30.1 & 7.81 & 0.619 & 0.06 \\
30.1 & 7.82 & 0.620 & 0.07 \\
30.1 & 7.81 & 0.622 & 0.07 \\
30.1 & 7.83 & 0.623 & 0.08 \\
30.1 & 7.82 & 0.624 & 0.09 \\
30.0 & 7.83 & 0.630 & 0.10 \\
30.0 & 7.84 & 0.635 & 0.11 \\
30.0 & 7.84 & 0.639 & 0.11 \\
30.0 & 7.85 & 0.642 & 0.12 \\
30.0 & 7.86 & 0.647 & 0.12 \\
30.0 & 7.86 & 0.650 & 0.13 \\
29.9 & 7.87 & 0.659 & 0.14 \\
29.9 & 7.87 & 0.662 & 0.15 \\
29.8 & 7.87 & 0.668 & 0.16 \\
29.8 & 7.88 & 0.671 & 0.16 \\
29.8 & 7.89 & 0.680 & 0.17 \\
29.7 & 7.90 & 0.691 & 0.19 \\
29.8 & 7.89 & 0.701 & 0.20 \\
30.0 & 7.90 & 0.710 & 0.21 \\
30.0 & 7.91 & 0.716 & 0.22 \\
29.9 & 7.92 & 0.723 & 0.24 \\
29.9 & 7.92 & 0.730 & 0.25 \\
29.7 & 7.93 & 0.736 & 0.26 \\
29.6 & 7.92 & 0.740 & 0.27 \\
29.7 & 7.93 & 0.745 & 0.29 \\
29.8 & 7.93 & 0.750 & 0.30 \\
29.8 & 7.93 & 0.754 & 0.31 \\
29.7 & 7.94 & 0.761 & 0.33 \\
29.6 & 7.95 & 0.767 & 0.35 \\
30.2 & 7.96 & 0.771 & 0.37 \\
30.2 & 7.95 & 0.773 & 0.39 \\
30.1 & 7.95 & 0.779 & 0.42 \\
30.1 & 7.95 & 0.779 & 0.42 \\
29.8 & 7.99 & 0.822 & 0.75 \\
29.8 & 8.00 & 0.844 & 1.07 \\
30.2 & 8.02 & 0.863 & 1.40 \\
29.9 & 8.05 & 0.872 & 1.73 \\
\hline & & & \\
\hline & 79 & \\
\hline
\end{tabular}


ORP Titration of SW at 30C using Free Chlorine (continued)

\begin{tabular}{cccc}
\hline Temperature ${ }^{\circ} \mathrm{C}$ & $\mathrm{pH}$ & Volts $(\mathrm{SHE})$ & $\mathrm{mg} / \mathrm{L} \mathrm{Cl}_{2}$ added \\
\hline 29.8 & 8.06 & 0.879 & 2.05 \\
29.7 & 8.07 & 0.885 & 2.38 \\
29.6 & 8.08 & 0.892 & 3.36 \\
29.6 & 8.10 & 0.900 & 4.34 \\
29.8 & 8.12 & 0.906 & 5.32 \\
30.1 & 8.13 & 0.912 & 6.95 \\
29.9 & 8.15 & 0.919 & 8.59 \\
\hline
\end{tabular}


Table A.24 ORP Titration of SW at 5C using Chloramine

\begin{tabular}{cccc}
\hline Temperature ${ }^{\circ} \mathrm{C}$ & $\mathrm{pH}$ & Volts $(\mathrm{SHE})$ & $\mathrm{mg} / \mathrm{L} \mathrm{Cl}_{2}$ added \\
\hline 5.5 & 7.95 & 0.570 & 0.00 \\
5.5 & 7.95 & 0.571 & 0.01 \\
5.5 & 7.95 & 0.575 & 0.01 \\
5.5 & 7.95 & 0.582 & 0.02 \\
5.4 & 7.95 & 0.592 & 0.03 \\
5.4 & 7.94 & 0.596 & 0.04 \\
5.4 & 7.94 & 0.602 & 0.04 \\
5.4 & 7.94 & 0.606 & 0.05 \\
5.4 & 7.94 & 0.611 & 0.06 \\
5.4 & 7.94 & 0.615 & 0.06 \\
5.4 & 7.94 & 0.618 & 0.07 \\
5.3 & 7.94 & 0.621 & 0.08 \\
5.3 & 7.94 & 0.627 & 0.09 \\
5.2 & 7.94 & 0.631 & 0.10 \\
5.1 & 7.93 & 0.636 & 0.11 \\
5.1 & 7.94 & 0.640 & 0.13 \\
5.0 & 7.93 & 0.643 & 0.14 \\
5.0 & 7.93 & 0.647 & 0.15 \\
5.0 & 7.93 & 0.651 & 0.18 \\
5.0 & 7.93 & 0.654 & 0.20 \\
5.0 & 7.93 & 0.659 & 0.24 \\
5.0 & 7.93 & 0.664 & 0.28 \\
5.1 & 7.93 & 0.669 & 0.33 \\
5.2 & 7.92 & 0.674 & 0.38 \\
5.3 & 7.93 & 0.678 & 0.44 \\
5.3 & 7.93 & 0.678 & 0.44 \\
5.4 & 7.93 & 0.688 & 0.67 \\
5.5 & 7.93 & 0.694 & 0.90 \\
5.6 & 7.93 & 0.700 & 1.36 \\
5.6 & 7.93 & 0.705 & 1.82 \\
5.7 & 7.93 & 0.71 & 2.74 \\
5.7 & 7.93 & 0.714 & 3.66 \\
5.7 & 7.92 & 0.717 & 5.04 \\
5.7 & 7.92 & 0.719 & 6.88 \\
5.7 & 7.91 & 0.721 & 9.18 \\
5.7 & 7.91 & 0.722 & 11.94 \\
\hline & & &
\end{tabular}


Table A.25 ORP Titration of SW at 10C using Chloramine

\begin{tabular}{cccc}
\hline Temperature ${ }^{\circ} \mathrm{C}$ & $\mathrm{pH}$ & Volts $(\mathrm{SHE})$ & $\mathrm{mg} / \mathrm{L} \mathrm{Cl}_{2}$ added \\
\hline 10.5 & 7.86 & 0.573 & 0.00 \\
10.2 & 7.86 & 0.575 & 0.01 \\
9.5 & 7.87 & 0.585 & 0.02 \\
9.1 & 7.87 & 0.591 & 0.03 \\
9.2 & 7.87 & 0.597 & 0.04 \\
9.4 & 7.88 & 0.604 & 0.05 \\
9.4 & 7.87 & 0.610 & 0.06 \\
9.4 & 7.88 & 0.614 & 0.07 \\
9.4 & 7.88 & 0.619 & 0.07 \\
9.4 & 7.87 & 0.623 & 0.08 \\
9.4 & 7.88 & 0.626 & 0.09 \\
9.5 & 7.88 & 0.630 & 0.10 \\
9.5 & 7.89 & 0.635 & 0.12 \\
9.7 & 7.88 & 0.639 & 0.13 \\
9.8 & 7.89 & 0.643 & 0.15 \\
9.8 & 7.89 & 0.647 & 0.17 \\
9.8 & 7.88 & 0.650 & 0.18 \\
9.8 & 7.90 & 0.653 & 0.20 \\
9.8 & 7.90 & 0.657 & 0.23 \\
9.8 & 7.90 & 0.659 & 0.25 \\
9.8 & 7.90 & 0.664 & 0.32 \\
9.8 & 7.91 & 0.668 & 0.38 \\
9.9 & 7.91 & 0.673 & 0.45 \\
9.9 & 7.91 & 0.676 & 0.55 \\
9.9 & 7.91 & 0.679 & 0.65 \\
9.9 & 7.91 & 0.679 & 0.65 \\
10.0 & 7.91 & 0.685 & 0.90 \\
10.0 & 7.91 & 0.689 & 1.15 \\
10.0 & 7.90 & 0.692 & 1.40 \\
10.1 & 7.90 & 0.694 & 1.65 \\
10.1 & 7.91 & 0.697 & 2.15 \\
10.1 & 7.90 & 0.699 & 3.15 \\
10.2 & 7.90 & 0.701 & 4.65 \\
10.3 & 7.91 & 0.703 & 7.15 \\
10.3 & 7.90 & 0.703 & 9.15 \\
10.4 & 7.89 & 0.704 & 11.65 \\
\hline & & &
\end{tabular}


Table A.26 ORP Titration of SW at 25C using Chloramine

\begin{tabular}{|c|c|c|c|}
\hline Temperature ${ }^{\circ} \mathrm{C}$ & $\mathrm{pH}$ & Volts (SHE) & $\mathrm{mg} / \mathrm{L} \mathrm{Cl}_{2}$ added \\
\hline 25.3 & 7.67 & 0.549 & 0.00 \\
\hline 25.4 & 7.67 & 0.553 & 0.01 \\
\hline 25.5 & 7.69 & 0.564 & 0.02 \\
\hline 25.6 & 7.71 & 0.575 & 0.03 \\
\hline 25.6 & 7.76 & 0.582 & 0.04 \\
\hline 25.6 & 7.83 & 0.593 & 0.05 \\
\hline 25.5 & 7.85 & 0.600 & 0.06 \\
\hline 25.5 & 7.87 & 0.606 & 0.07 \\
\hline 25.4 & 7.86 & 0.610 & 0.08 \\
\hline 25.4 & 7.86 & 0.613 & 0.08 \\
\hline 25.3 & 7.86 & 0.619 & 0.09 \\
\hline 25.3 & 7.86 & 0.622 & 0.10 \\
\hline 25.2 & 7.86 & 0.626 & 0.11 \\
\hline 25.2 & 7.87 & 0.629 & 0.12 \\
\hline 25.1 & 7.87 & 0.631 & 0.13 \\
\hline 25.1 & 7.87 & 0.633 & 0.13 \\
\hline 25.1 & 7.88 & 0.635 & 0.14 \\
\hline 25.0 & 7.88 & 0.638 & 0.15 \\
\hline 25.0 & 7.89 & 0.639 & 0.16 \\
\hline 25.0 & 7.88 & 0.642 & 0.18 \\
\hline 24.9 & 7.89 & 0.645 & 0.19 \\
\hline 24.9 & 7.89 & 0.649 & 0.22 \\
\hline 24.8 & 7.90 & 0.653 & 0.25 \\
\hline 24.8 & 7.89 & 0.658 & 0.30 \\
\hline 24.7 & 7.90 & 0.663 & 0.38 \\
\hline 24.7 & 7.90 & 0.663 & 0.38 \\
\hline 24.6 & 7.91 & 0.669 & 0.88 \\
\hline 24.5 & 7.92 & 0.673 & 1.38 \\
\hline 24.5 & 7.92 & 0.675 & 1.88 \\
\hline 24.4 & 7.92 & 0.679 & 2.88 \\
\hline 24.4 & 7.91 & 0.683 & 4.88 \\
\hline 24.4 & 7.91 & 0.685 & 6.63 \\
\hline 24.3 & 7.91 & 0.686 & 8.38 \\
\hline 24.3 & 7.9 & 0.687 & 8.88 \\
\hline
\end{tabular}


Table A.27 ORP Titration of SW at 30C using Chloramine

\begin{tabular}{cccc}
\hline Temperature ${ }^{\circ} \mathrm{C}$ & $\mathrm{pH}$ & Volts $(\mathrm{SHE})$ & $\mathrm{mg} / \mathrm{L} \mathrm{Cl}_{2}$ added \\
\hline 29.4 & 7.84 & 0.550 & 0.00 \\
31.5 & 7.87 & 0.555 & 0.01 \\
32.9 & 7.88 & 0.564 & 0.03 \\
33.3 & 7.89 & 0.578 & 0.04 \\
33.0 & 7.92 & 0.591 & 0.06 \\
32.7 & 7.94 & 0.600 & 0.07 \\
32.0 & 7.95 & 0.609 & 0.09 \\
31.8 & 8.00 & 0.617 & 0.11 \\
31.5 & 8.00 & 0.624 & 0.14 \\
31.3 & 8.02 & 0.632 & 0.18 \\
30.8 & 8.02 & 0.641 & 0.25 \\
30.8 & 8.02 & 0.641 & 0.25 \\
30.4 & 8.04 & 0.655 & 0.50 \\
30.2 & 8.04 & 0.662 & 0.74 \\
29.9 & 8.05 & 0.669 & 1.23 \\
29.7 & 8.05 & 0.677 & 2.21 \\
29.6 & 8.05 & 0.681 & 4.17 \\
29.5 & 8.03 & 0.684 & 8.09 \\
29.5 & 8.03 & 0.685 & 10.05 \\
29.4 & 8.02 & 0.686 & 11.52 \\
29.4 & 8.02 & 0.686 & 12.99 \\
\hline
\end{tabular}


Table A.28 ORP Titration of SW at $25 \mathrm{C}$ using Free Chlorine with $50 \mathrm{mg} / \mathrm{L} \mathrm{SO}_{4}{ }^{-2}$

\begin{tabular}{cccc}
\hline Temperature ${ }^{\circ} \mathrm{C}$ & $\mathrm{pH}$ & Volts $(\mathrm{SHE})$ & $\mathrm{mg} / \mathrm{L} \mathrm{Cl}_{2}$ added \\
\hline 23.5 & 7.97 & 0.587 & 0.00 \\
23.8 & 7.97 & 0.585 & 0.01 \\
24.1 & 7.98 & 0.586 & 0.02 \\
24.5 & 7.98 & 0.588 & 0.04 \\
24.7 & 7.98 & 0.593 & 0.05 \\
25.0 & 7.98 & 0.595 & 0.07 \\
25.1 & 7.98 & 0.600 & 0.08 \\
25.5 & 7.99 & 0.607 & 0.09 \\
25.6 & 7.99 & 0.615 & 0.11 \\
25.9 & 7.99 & 0.625 & 0.12 \\
26.0 & 7.99 & 0.645 & 0.14 \\
26.2 & 8.00 & 0.662 & 0.16 \\
26.4 & 8.01 & 0.676 & 0.18 \\
26.4 & 8.01 & 0.689 & 0.20 \\
26.4 & 8.01 & 0.703 & 0.23 \\
26.4 & 8.01 & 0.714 & 0.25 \\
26.3 & 8.02 & 0.723 & 0.28 \\
26.3 & 8.02 & 0.734 & 0.32 \\
26.2 & 8.03 & 0.744 & 0.36 \\
26.1 & 8.04 & 0.754 & 0.41 \\
26.0 & 8.04 & 0.764 & 0.48 \\
25.9 & 8.05 & 0.772 & 0.55 \\
25.9 & 8.05 & 0.772 & 0.55 \\
25.8 & 8.05 & 0.796 & 0.90 \\
25.5 & 8.06 & 0.814 & 1.25 \\
25.5 & 8.06 & 0.832 & 1.60 \\
25.2 & 8.08 & 0.844 & 1.95 \\
25.2 & 8.09 & 0.853 & 2.30 \\
25.3 & 8.10 & 0.864 & 3.00 \\
25.4 & 8.13 & 0.876 & 4.05 \\
25.4 & 8.16 & 0.884 & 5.45 \\
25.5 & 8.20 & 0.893 & 7.55 \\
25.5 & 8.22 & 0.901 & 9.65 \\
25.6 & 8.24 & 0.905 & 11.05 \\
25.6 & 8.26 & 0.906 & 12.45 \\
\hline & & &
\end{tabular}


Table A.29 ORP Titration of SW at $25 \mathrm{C}$ using Free Chlorine with $100 \mathrm{mg} / \mathrm{L} \mathrm{SO}_{4}^{-2}$

\begin{tabular}{cccc}
\hline Temperature ${ }^{\circ} \mathrm{C}$ & $\mathrm{pH}$ & Volts $(\mathrm{SHE})$ & $\mathrm{mg} / \mathrm{L} \mathrm{Cl}_{2}$ added \\
\hline 28.4 & 7.86 & 0.562 & 0.00 \\
28.0 & 7.88 & 0.562 & 0.01 \\
27.7 & 7.88 & 0.565 & 0.03 \\
27.4 & 7.88 & 0.574 & 0.05 \\
26.9 & 7.89 & 0.596 & 0.07 \\
26.6 & 7.89 & 0.621 & 0.10 \\
26.4 & 7.91 & 0.661 & 0.13 \\
26.1 & 7.92 & 0.691 & 0.17 \\
25.9 & 7.94 & 0.718 & 0.21 \\
25.8 & 7.94 & 0.736 & 0.25 \\
25.6 & 7.95 & 0.751 & 0.29 \\
25.5 & 7.96 & 0.764 & 0.33 \\
25.4 & 7.97 & 0.773 & 0.37 \\
25.3 & 7.97 & 0.784 & 0.41 \\
25.2 & 7.98 & 0.794 & 0.47 \\
25.1 & 7.98 & 0.807 & 0.57 \\
25.0 & 7.99 & 0.823 & 0.70 \\
25.0 & 7.99 & 0.823 & 0.70 \\
24.9 & 8.01 & 0.844 & 1.06 \\
24.8 & 8.03 & 0.874 & 2.14 \\
24.6 & 8.06 & 0.890 & 3.22 \\
24.5 & 8.09 & 0.904 & 5.38 \\
24.5 & 8.14 & 0.914 & 8.26 \\
24.4 & 8.18 & 0.921 & 11.50 \\
\hline
\end{tabular}


Table A.30 ORP Titration of SW at $25 \mathrm{C}$ using Free Chlorine with $150 \mathrm{mg} / \mathrm{L} \mathrm{SO}_{4}{ }^{-2}$

\begin{tabular}{|c|c|c|c|}
\hline Temperature ${ }^{\circ} \mathrm{C}$ & $\mathrm{pH}$ & Volts (SHE) & $\mathrm{mg} / \mathrm{L} \mathrm{Cl}_{2}$ added \\
\hline 20.7 & 7.79 & 0.52 .5 & 0.00 \\
\hline 20.7 & 7.79 & 0.525 & 0.01 \\
\hline 20.7 & 7.79 & 0.526 & 0.01 \\
\hline 20.7 & 7.79 & 0.527 & 0.02 \\
\hline 20.8 & 7.80 & 0.529 & 0.03 \\
\hline 20.8 & 7.79 & 0.532 & 0.03 \\
\hline 20.8 & 7.79 & 0.535 & 0.04 \\
\hline 20.8 & 7.80 & 0.540 & 0.05 \\
\hline 20.8 & 7.79 & 0.544 & 0.05 \\
\hline 20.8 & 7.80 & 0.549 & 0.06 \\
\hline 20.9 & 7.80 & 0.554 & 0.07 \\
\hline 20.9 & 7.80 & 0.559 & 0.07 \\
\hline 20.9 & 7.80 & 0.565 & 0.08 \\
\hline 20.9 & 7.80 & 0.571 & 0.09 \\
\hline 20.9 & 7.79 & 0.576 & 0.09 \\
\hline 21.0 & 7.80 & 0.581 & 0.10 \\
\hline 21.0 & 7.80 & 0.587 & 0.11 \\
\hline 21.0 & 7.80 & 0.593 & 0.11 \\
\hline 21.0 & 7.80 & 0.599 & 0.12 \\
\hline 21.1 & 7.80 & 0.605 & 0.13 \\
\hline 21.1 & 7.80 & 0.611 & 0.13 \\
\hline 21.1 & 7.81 & 0.622 & 0.15 \\
\hline 21.1 & 7.80 & 0.635 & 0.16 \\
\hline 21.1 & 7.80 & 0.645 & 0.17 \\
\hline 21.2 & 7.81 & 0.656 & 0.19 \\
\hline 21.2 & 7.80 & 0.666 & 0.20 \\
\hline 21.2 & 7.81 & 0.675 & 0.21 \\
\hline 21.3 & 7.80 & 0.683 & 0.23 \\
\hline 21.3 & 7.81 & 0.691 & 0.24 \\
\hline 21.3 & 7.81 & 0.698 & 0.25 \\
\hline 21.3 & 7.81 & 0.705 & 0.27 \\
\hline 21.4 & 7.81 & 0.711 & 0.28 \\
\hline 21.4 & 7.81 & 0.718 & 0.29 \\
\hline 21.4 & 7.80 & 0.728 & 0.31 \\
\hline 21.5 & 7.81 & 0.735 & 0.33 \\
\hline 21.5 & 7.81 & 0.742 & 0.35 \\
\hline 21.5 & 7.82 & 0.749 & 0.37 \\
\hline 21.5 & 7.82 & 0.755 & 0.40 \\
\hline 21.6 & 7.82 & 0.762 & 0.43 \\
\hline 21.6 & 7.83 & 0.771 & 0.47 \\
\hline 21.6 & 7.83 & 0.771 & 0.47 \\
\hline 21.6 & 7.83 & 0.800 & 0.78 \\
\hline 21.7 & 7.85 & 0.829 & 1.10 \\
\hline 21.7 & 7.87 & 0.849 & 1.42 \\
\hline 21.7 & 7.86 & 0.867 & 1.73 \\
\hline 21.8 & 7.87 & 0.874 & 2.05 \\
\hline
\end{tabular}


ORP Titration of SW at $25 \mathrm{C}$ using Free Chlorine with $150 \mathrm{mg} / \mathrm{L} \mathrm{SO}_{4}^{-2}$ (continued)

\begin{tabular}{cccc}
\hline Temperature ${ }^{\circ} \mathrm{C}$ & $\mathrm{pH}$ & Volts $(\mathrm{SHE})$ & $\mathrm{mg} / \mathrm{L} \mathrm{Cl}_{2}$ added \\
\hline 2.1 & 7.89 & 0.881 & 2.68 \\
22.9 & 7.90 & 0.889 & 3.63 \\
23.7 & 7.93 & 0.896 & 4.90 \\
24.3 & 7.96 & 0.902 & 6.17 \\
24.9 & 8.00 & 0.908 & 8.07 \\
25.0 & 8.03 & 0.912 & 9.33 \\
25.1 & 8.06 & 0.915 & 10.92 \\
25.3 & 8.08 & 0.918 & 11.55 \\
\hline
\end{tabular}


Table A.31 ORP Titration of SW at $25 \mathrm{C}$ using Chloramine with $50 \mathrm{mg} / \mathrm{L} \mathrm{SO}_{4}{ }^{-2}$

\begin{tabular}{|c|c|c|c|}
\hline Temperature ${ }^{\circ} \mathrm{C}$ & $\mathrm{pH}$ & Volts (SHE) & $\mathrm{mg} / \mathrm{L} \mathrm{Cl} \mathrm{Cl}_{2}$ added \\
\hline 24.5 & 7.98 & 0.526 & 0.00 \\
\hline 24.5 & 7.98 & 0.530 & 0.01 \\
\hline 24.6 & 7.98 & 0.545 & 0.02 \\
\hline 24.9 & 7.98 & 0.554 & 0.03 \\
\hline 25.0 & 7.98 & 0.563 & 0.03 \\
\hline 25.0 & 7.98 & 0.569 & 0.04 \\
\hline 25.0 & 7.99 & 0.576 & 0.04 \\
\hline 25.0 & 7.99 & 0.581 & 0.05 \\
\hline 25.1 & 7.99 & 0.586 & 0.06 \\
\hline 25.2 & 7.99 & 0.590 & 0.06 \\
\hline 25.3 & 7.99 & 0.594 & 0.07 \\
\hline 25.3 & 7.99 & 0.597 & 0.08 \\
\hline 25.4 & 7.99 & 0.602 & 0.09 \\
\hline 25.4 & 7.99 & 0.607 & 0.10 \\
\hline 25.3 & 7.99 & 0.612 & 0.11 \\
\hline 25.3 & 7.99 & 0.615 & 0.13 \\
\hline 25.3 & 8.00 & 0.620 & 0.15 \\
\hline 25.3 & 8.00 & 0.628 & 0.19 \\
\hline 25.2 & 8.00 & 0.634 & 0.24 \\
\hline 25.1 & 8.00 & 0.640 & 0.29 \\
\hline 25.1 & 8.00 & 0.645 & 0.35 \\
\hline 25.1 & 8.00 & 0.645 & 0.35 \\
\hline 24.9 & 8.00 & 0.656 & 0.58 \\
\hline 24.9 & 8.00 & 0.666 & 1.04 \\
\hline 24.9 & 8.00 & 0.674 & 1.73 \\
\hline 24.8 & 8.00 & 0.678 & 2.65 \\
\hline 24.8 & 7.99 & 0.682 & 4.03 \\
\hline 24.8 & 7.99 & 0.684 & 5.87 \\
\hline 24.7 & 7.98 & 0.685 & 8.40 \\
\hline 24.7 & 7.96 & 0.687 & 10.47 \\
\hline 24.6 & 7.95 & 0.688 & 12.31 \\
\hline
\end{tabular}


Table A.32 ORP Titration of SW at $25 \mathrm{C}$ using Chloramine with $100 \mathrm{mg} / \mathrm{L} \mathrm{SO}_{4}{ }^{-2}$

\begin{tabular}{cccc}
\hline Temperature ${ }^{\circ} \mathrm{C}$ & $\mathrm{pH}$ & Volts $(\mathrm{SHE})$ & $\mathrm{mg} / \mathrm{L} \mathrm{Cl}_{2}$ added \\
\hline 23.4 & 7.95 & 0.568 & 0.00 \\
24.1 & 7.95 & 0.569 & 0.01 \\
24.5 & 7.95 & 0.572 & 0.02 \\
25.1 & 7.96 & 0.579 & 0.03 \\
25.3 & 7.96 & 0.591 & 0.04 \\
25.6 & 7.97 & 0.601 & 0.05 \\
25.6 & 7.97 & 0.609 & 0.06 \\
25.6 & 7.98 & 0.617 & 0.08 \\
25.5 & 7.99 & 0.626 & 0.11 \\
25.5 & 7.99 & 0.634 & 0.15 \\
25.4 & 7.99 & 0.640 & 0.18 \\
25.3 & 8.00 & 0.646 & 0.23 \\
25.3 & 8.00 & 0.651 & 0.29 \\
25.2 & 8.00 & 0.656 & 0.37 \\
25.2 & 8.00 & 0.656 & 0.37 \\
25.1 & 8.00 & 0.665 & 0.60 \\
25.1 & 8.00 & 0.669 & 0.83 \\
25.1 & 8.00 & 0.675 & 1.29 \\
25.0 & 8.00 & 0.680 & 1.98 \\
25.0 & 8.00 & 0.682 & 2.67 \\
25.0 & 7.99 & 0.685 & 4.05 \\
24.9 & 7.98 & 0.686 & 6.35 \\
24.9 & 7.97 & 0.687 & 8.65 \\
24.9 & 7.95 & 0.688 & 11.87 \\
24.8 & 7.94 & 0.688 & 13.25 \\
\hline & & &
\end{tabular}


Table A.33 ORP Titration of SW at $25 \mathrm{C}$ using Chloramine with $150 \mathrm{mg} / \mathrm{L} \mathrm{SO}_{4}{ }^{-2}$

\begin{tabular}{cccc}
\hline Temperature ${ }^{\circ} \mathrm{C}$ & $\mathrm{pH}$ & Volts $(\mathrm{SHE})$ & $\mathrm{mg} / \mathrm{L} \mathrm{Cl}_{2}$ added \\
\hline 24.6 & 8.06 & 0.533 & 0.00 \\
24.7 & 8.06 & 0.537 & 0.01 \\
24.8 & 8.07 & 0.546 & 0.01 \\
24.9 & 8.07 & 0.555 & 0.02 \\
24.9 & 8.07 & 0.564 & 0.03 \\
25.0 & 8.07 & 0.573 & 0.03 \\
25.0 & 8.07 & 0.579 & 0.04 \\
25.1 & 8.07 & 0.586 & 0.04 \\
25.1 & 8.07 & 0.591 & 0.05 \\
25.2 & 8.08 & 0.597 & 0.06 \\
25.2 & 8.08 & 0.601 & 0.06 \\
25.2 & 8.08 & 0.606 & 0.07 \\
25.2 & 8.08 & 0.610 & 0.08 \\
25.2 & 8.08 & 0.613 & 0.08 \\
25.1 & 8.08 & 0.616 & 0.09 \\
25.1 & 8.09 & 0.620 & 0.10 \\
25.0 & 8.08 & 0.624 & 0.11 \\
25.0 & 8.08 & 0.629 & 0.13 \\
25.0 & 8.08 & 0.633 & 0.15 \\
24.9 & 8.08 & 0.638 & 0.18 \\
24.9 & 8.08 & 0.643 & 0.22 \\
24.8 & 8.08 & 0.649 & 0.27 \\
24.8 & 8.08 & 0.654 & 0.32 \\
24.8 & 8.09 & 0.659 & 0.38 \\
24.8 & 8.09 & 0.659 & 0.38 \\
24.6 & 8.09 & 0.673 & 0.84 \\
24.6 & 8.09 & 0.681 & 1.30 \\
24.7 & 8.09 & 0.686 & 1.76 \\
24.8 & 8.08 & 0.688 & 2.22 \\
24.8 & 8.08 & 0.69 & 2.91 \\
24.9 & 8.08 & 0.691 & 3.60 \\
24.9 & 8.07 & 0.692 & 4.52 \\
24.9 & 8.06 & 0.693 & 5.90 \\
24.9 & 8.05 & 0.694 & 7.74 \\
24.9 & 8.04 & 0.695 & 10.04 \\
24.9 & 8.03 & 0.696 & 12.34 \\
24.9 & 8.01 & 0.697 & 14.64 \\
\hline & & & \\
\hline & 8.96 & \\
\hline
\end{tabular}


Table A.34 ORP Titration of RO at 5C using Free Chlorine

\begin{tabular}{|c|c|c|c|}
\hline Temperature ${ }^{\circ} \mathrm{C}$ & $\mathrm{pH}$ & Volts (SHE) & $\mathrm{mg} / \mathrm{L} \mathrm{Cl}{ }_{2}$ added \\
\hline 5.5 & 7.67 & 0.722 & 0.00 \\
\hline 5.5 & 7.67 & 0.720 & 0.01 \\
\hline 5.4 & 7.67 & 0.716 & 0.01 \\
\hline 5.2 & 7.66 & 0.710 & 0.01 \\
\hline 5.1 & 7.65 & 0.708 & 0.03 \\
\hline 5.1 & 7.65 & 0.705 & 0.03 \\
\hline 5.0 & 7.65 & 0.699 & 0.05 \\
\hline 4.9 & 7.63 & 0.694 & 0.06 \\
\hline 4.8 & 7.61 & 0.695 & 0.09 \\
\hline 4.8 & 7.60 & 0.695 & 0.11 \\
\hline 4.7 & 7.60 & 0.699 & 0.13 \\
\hline 4.7 & 7.59 & 0.703 & 0.14 \\
\hline 4.7 & 7.58 & 0.711 & 0.15 \\
\hline 4.6 & 7.57 & 0.717 & 0.16 \\
\hline 4.5 & 7.55 & 0.722 & 0.17 \\
\hline 4.4 & 7.55 & 0.734 & 0.18 \\
\hline 4.4 & 7.55 & 0.74 & 0.19 \\
\hline 4.4 & 7.54 & 0.748 & 0.19 \\
\hline 4.4 & 7.55 & 0.754 & 0.20 \\
\hline 4.5 & 7.54 & 0.758 & 0.21 \\
\hline 4.6 & 7.54 & 0.762 & 0.21 \\
\hline 4.7 & 7.54 & 0.767 & 0.22 \\
\hline 4.7 & 7.55 & 0.769 & 0.23 \\
\hline 4.7 & 7.55 & 0.777 & 0.24 \\
\hline 4.7 & 7.55 & 0.781 & 0.25 \\
\hline 4.7 & 7.55 & 0.785 & 0.26 \\
\hline 4.7 & 7.56 & 0.789 & 0.26 \\
\hline 4.7 & 7.57 & 0.794 & 0.28 \\
\hline 4.8 & 7.56 & 0.799 & 0.28 \\
\hline 4.9 & 7.58 & 0.802 & 0.29 \\
\hline 4.9 & 7.57 & 0.806 & 0.30 \\
\hline 4.9 & 7.57 & 0.809 & 0.30 \\
\hline 5.0 & 7.68 & 0.813 & 0.32 \\
\hline 5.0 & 7.57 & 0.819 & 0.33 \\
\hline 5.1 & 7.56 & 0.828 & 0.35 \\
\hline 5.1 & 7.57 & 0.833 & 0.36 \\
\hline 5.1 & 7.57 & 0.838 & 0.37 \\
\hline 4.9 & 7.57 & 0.845 & 0.39 \\
\hline 4.9 & 7.57 & 0.849 & 0.40 \\
\hline 5 & 7.58 & 0.853 & 0.41 \\
\hline 4.9 & 7.58 & 0.858 & 0.42 \\
\hline 4.7 & 7.58 & 0.86 & 0.44 \\
\hline 4.7 & 7.58 & 0.864 & 0.45 \\
\hline 4.8 & 7.58 & 0.871 & 0.48 \\
\hline
\end{tabular}


ORP Titration of RO at 5C using Free Chlorine (continued)

\begin{tabular}{cccc}
\hline Temperature ${ }^{\circ} \mathrm{C}$ & $\mathrm{pH}$ & Volts $(\mathrm{SHE})$ & $\mathrm{mg} / \mathrm{L} \mathrm{Cl}_{2}$ added \\
\hline 5.0 & 7.58 & 0.879 & 0.51 \\
5.2 & 7.58 & 0.887 & 0.57 \\
5.2 & 7.58 & 0.887 & 0.57 \\
5.2 & 7.64 & 0.917 & 2.50 \\
5.2 & 7.66 & 0.935 & 3.14 \\
5.2 & 7.71 & 0.945 & 4.10 \\
5.3 & 7.74 & 0.954 & 4.75 \\
5.3 & 7.77 & 0.961 & 6.03 \\
5.4 & 7.81 & 0.967 & 7.64 \\
5.5 & 7.84 & 0.970 & 8.93 \\
5.5 & 7.86 & 0.974 & 10.22 \\
\hline
\end{tabular}


Table A. 35 ORP Titration of RO at $15 \mathrm{C}$ using Free Chlorine

\begin{tabular}{|c|c|c|c|}
\hline Temperature ${ }^{\circ} \mathrm{C}$ & $\mathrm{pH}$ & Volts (SHE) & $\mathrm{mg} / \mathrm{L} \mathrm{Cl}{ }_{2}$ added \\
\hline 14.5 & 7.44 & 0.631 & 0.00 \\
\hline 14.6 & 7.44 & 0.634 & 0.01 \\
\hline 14.5 & 7.44 & 0.636 & 0.01 \\
\hline 14.4 & 7.46 & 0.641 & 0.02 \\
\hline 14.6 & 7.47 & 0.646 & 0.02 \\
\hline 14.8 & 7.47 & 0.652 & 0.03 \\
\hline 15.0 & 7.47 & 0.666 & 0.04 \\
\hline 15.2 & 7.45 & 0.683 & 0.05 \\
\hline 15.2 & 7.44 & 0.701 & 0.06 \\
\hline 15.2 & 7.45 & 0.720 & 0.06 \\
\hline 14.7 & 7.46 & 0.737 & 0.07 \\
\hline 14.5 & 7.46 & 0.758 & 0.07 \\
\hline 14.6 & 7.46 & 0.770 & 0.08 \\
\hline 14.7 & 7.46 & 0.780 & 0.09 \\
\hline 14.8 & 7.50 & 0.791 & 0.09 \\
\hline 14.9 & 7.52 & 0.801 & 0.11 \\
\hline 15.0 & 7.52 & 0.814 & 0.11 \\
\hline 15.1 & 7.51 & 0.826 & 0.12 \\
\hline 15.2 & 7.49 & 0.835 & 0.12 \\
\hline 15.3 & 7.48 & 0.842 & 0.13 \\
\hline 15.3 & 7.49 & 0.850 & 0.14 \\
\hline 15.3 & 7.48 & 0.856 & 0.14 \\
\hline 15.3 & 7.49 & 0.861 & 0.16 \\
\hline 15.3 & 7.50 & 0.864 & 0.16 \\
\hline 15.4 & 7.50 & 0.871 & 0.17 \\
\hline 15.4 & 7.50 & 0.878 & 0.18 \\
\hline 15.1 & 7.50 & 0.885 & 0.19 \\
\hline 14.7 & 7.50 & 0.893 & 0.20 \\
\hline 14.6 & 7.51 & 0.898 & 0.22 \\
\hline 14.5 & 7.52 & 0.902 & 0.23 \\
\hline 14.5 & 7.51 & 0.906 & 0.25 \\
\hline 14.5 & 7.51 & 0.910 & 0.27 \\
\hline 14.6 & 7.52 & 0.914 & 0.30 \\
\hline 14.6 & 7.52 & 0.914 & 0.30 \\
\hline 14.7 & 7.55 & 0.935 & 0.62 \\
\hline 14.8 & 7.57 & 0.943 & 0.95 \\
\hline 14.9 & 7.59 & 0.950 & 1.28 \\
\hline 15.0 & 7.61 & 0.955 & 1.60 \\
\hline 15.1 & 7.69 & 0.963 & 3.56 \\
\hline 15.2 & 7.74 & 0.972 & 5.52 \\
\hline 15.4 & 7.80 & 0.976 & 7.48 \\
\hline 15.5 & 7.86 & 0.980 & 10.10 \\
\hline
\end{tabular}


Table A.36 ORP Titration of RO at 25C using Free Chlorine

\begin{tabular}{|c|c|c|c|}
\hline Temperature ${ }^{\circ} \mathrm{C}$ & $\mathrm{pH}$ & Volts (SHE) & $\mathrm{mg} / \mathrm{L} \mathrm{Cl}{ }_{2}$ added \\
\hline 227 & 788 & 0525 & 000 \\
\hline 22.6 & 7.89 & 0.524 & 0.01 \\
\hline 22.6 & 7.89 & 0.526 & 0.01 \\
\hline 22.6 & 7.90 & 0.529 & 0.02 \\
\hline 22.6 & 7.89 & 0.532 & 0.02 \\
\hline 22.6 & 7.89 & 0.538 & 0.03 \\
\hline 22.6 & 7.89 & 0.544 & 0.04 \\
\hline 22.6 & 7.90 & 0.552 & 0.04 \\
\hline 22.6 & 7.90 & 0.562 & 0.05 \\
\hline 22.6 & 7.90 & 0.573 & 0.05 \\
\hline 22.7 & 7.89 & 0.584 & 0.06 \\
\hline 22.7 & 7.89 & 0.594 & 0.07 \\
\hline 22.7 & 7.88 & 0.605 & 0.07 \\
\hline 22.7 & 7.88 & 0.624 & 0.08 \\
\hline 22.7 & 7.88 & 0.641 & 0.10 \\
\hline 22.7 & 7.88 & 0.660 & 0.11 \\
\hline 22.8 & 7.88 & 0.671 & 0.12 \\
\hline 22.8 & 7.86 & 0.680 & 0.13 \\
\hline 22.8 & 7.85 & 0.686 & 0.13 \\
\hline 22.9 & 7.86 & 0.696 & 0.14 \\
\hline 22.9 & 7.87 & 0.704 & 0.16 \\
\hline 22.9 & 7.86 & 0.714 & 0.17 \\
\hline 23.0 & 7.85 & 0.723 & 0.18 \\
\hline 23.0 & 7.86 & 0.735 & 0.20 \\
\hline 23.1 & 7.82 & 0.754 & 0.23 \\
\hline 23.1 & 7.81 & 0.768 & 0.25 \\
\hline 23.2 & 7.81 & 0.782 & 0.29 \\
\hline 23.3 & 7.81 & 0.792 & 0.30 \\
\hline 23.3 & 7.78 & 0.800 & 0.33 \\
\hline 23.3 & 7.77 & 0.812 & 0.38 \\
\hline 23.3 & 7.76 & 0.819 & 0.42 \\
\hline 23.3 & 7.76 & 0.819 & 0.42 \\
\hline 23.4 & 7.78 & 0.847 & 0.75 \\
\hline 23.5 & 7.78 & 0.857 & 1.08 \\
\hline 23.5 & 7.82 & 0.867 & 1.75 \\
\hline 23.5 & 7.60 & 0.878 & 3.42 \\
\hline 23.5 & 7.90 & 0.890 & 5.75 \\
\hline 23.6 & 7.96 & 0.897 & 7.75 \\
\hline 23.6 & 8.02 & 0.902 & 10.42 \\
\hline
\end{tabular}


Table A.37 ORP Titration of RO at 30C using Free Chlorine

\begin{tabular}{cccc}
\hline Temperature ${ }^{\circ} \mathrm{C}$ & $\mathrm{pH}$ & Volts $(\mathrm{SHE})$ & $\mathrm{mg} / \mathrm{L} \mathrm{Cl}_{2}$ added \\
\hline 310 & 778 & 0.533 & 000 \\
30.7 & 7.52 & 0.537 & 0.01 \\
30.6 & 7.53 & 0.545 & 0.01 \\
30.5 & 7.53 & 0.553 & 0.02 \\
30.4 & 7.52 & 0.563 & 0.02 \\
30.3 & 7.53 & 0.571 & 0.03 \\
30.2 & 7.53 & 0.580 & 0.04 \\
30.2 & 7.53 & 0.587 & 0.04 \\
30.1 & 7.53 & 0.595 & 0.05 \\
30.0 & 7.54 & 0.603 & 0.05 \\
29.9 & 7.54 & 0.612 & 0.06 \\
29.9 & 7.54 & 0.621 & 0.07 \\
29.8 & 7.54 & 0.630 & 0.07 \\
29.8 & 7.55 & 0.640 & 0.08 \\
29.7 & 7.56 & 0.650 & 0.08 \\
29.7 & 7.55 & 0.660 & 0.09 \\
29.6 & 7.56 & 0.669 & 0.10 \\
29.6 & 7.56 & 0.678 & 0.10 \\
29.5 & 7.56 & 0.685 & 0.11 \\
29.4 & 7.56 & 0.691 & 0.11 \\
29.7 & 7.55 & 0.697 & 0.12 \\
29.6 & 7.55 & 0.705 & 0.13 \\
29.7 & 7.55 & 0.712 & 0.14 \\
29.6 & 7.55 & 0.718 & 0.14 \\
29.6 & 7.56 & 0.725 & 0.15 \\
29.6 & 7.55 & 0.728 & 0.16 \\
29.8 & 7.55 & 0.733 & 0.16 \\
29.7 & 7.56 & 0.736 & 0.17 \\
29.7 & 7.56 & 0.74 & 0.17 \\
29.7 & 7.56 & 0.746 & 0.18 \\
29.7 & 7.56 & 0.752 & 0.18 \\
29.7 & 7.56 & 0.757 & 0.19 \\
29.6 & 7.55 & 0.763 & 0.20 \\
29,5 & 7.55 & 0.769 & 0.21 \\
29.7 & 7.54 & 0.774 & 0.21 \\
29.9 & 7.54 & 0.777 & 0.22 \\
29.8 & 7.54 & 0.787 & 0.23 \\
29.7 & 7.53 & 0.804 & 0.27 \\
29.6 & 7.53 & 0.811 & 0.28 \\
29.5 & 7.54 & 0.814 & 0.29 \\
29.6 & 7.53 & 0.819 & 0.30 \\
29.6 & 7.54 & 0.824 & 0.32 \\
29.5 & 7.54 & 0.829 & 0.34 \\
29.6 & 7.54 & 0.832 & \\
\hline & & & 0.03 \\
\hline
\end{tabular}


ORP Titration of RO at $30 \mathrm{C}$ using Free Chlorine (continued)

\begin{tabular}{cccc}
\hline Temperature ${ }^{\circ} \mathrm{C}$ & $\mathrm{pH}$ & Volts $(\mathrm{SHE})$ & $\mathrm{mg} / \mathrm{L} \mathrm{Cl}_{2}$ added \\
\hline 29.7 & 7.55 & 0.835 & 0.35 \\
29.7 & 7.55 & 0.837 & 0.36 \\
29.7 & 7.55 & 0.837 & 0.36 \\
29.6 & 7.59 & 0.852 & 0.69 \\
29.6 & 7.61 & 0.862 & 1.02 \\
29.5 & 7.64 & 0.868 & 1.34 \\
29.7 & 7.64 & 0.872 & 1.67 \\
29.9 & 7.71 & 0.883 & 3.63 \\
29.8 & 7.80 & 0.891 & 5.59 \\
29.7 & 7.83 & 0.896 & 7.88 \\
\hline
\end{tabular}


Table A.38 ORP Titration of RO at 5C using Chloramine

\begin{tabular}{cccc}
\hline Temperature ${ }^{\circ} \mathrm{C}$ & $\mathrm{pH}$ & Volts $(\mathrm{SHE})$ & $\mathrm{mg} / \mathrm{L} \mathrm{Cl}_{2}$ added \\
\hline 6.9 & 7.64 & 0.644 & 0.00 \\
6.7 & 7.64 & 0.644 & 0.01 \\
6.6 & 7.64 & 0.645 & 0.03 \\
6.3 & 7.64 & 0.649 & 0.05 \\
5.9 & 7.64 & 0.655 & 0.07 \\
5.3 & 7.63 & 0.670 & 0.10 \\
5.0 & 7.63 & 0.678 & 0.12 \\
4.9 & 7.63 & 0.682 & 0.15 \\
4.9 & 7.62 & 0.686 & 0.17 \\
4.8 & 7.62 & 0.692 & 0.21 \\
4.7 & 7.63 & 0.694 & 0.25 \\
4.7 & 7.62 & 0.696 & 0.27 \\
4.7 & 7.62 & 0.698 & 0.35 \\
4.7 & 7.62 & 0.698 & 0.35 \\
4.6 & 7.62 & 0.705 & 0.53 \\
4.5 & 7.62 & 0.713 & 0.71 \\
4.5 & 7.62 & 0.720 & 1.60 \\
4.5 & 7.61 & 0.723 & 2.31 \\
4.5 & 7.61 & 0.725 & 3.38 \\
4.5 & 7.60 & 0.726 & 4.81 \\
4.5 & 7.60 & 0.727 & 6.59 \\
4.5 & 7.59 & 0.728 & 8.37 \\
4.5 & 7.59 & 0.728 & 9.80 \\
4.5 & 7.59 & 0.728 & 10.87 \\
\hline
\end{tabular}


Table A.39 ORP Titration of RO at 10C using Chloramine

\begin{tabular}{cccc}
\hline Temperature ${ }^{\circ} \mathrm{C}$ & $\mathrm{pH}$ & Volts $(\mathrm{SHE})$ & $\mathrm{mg} / \mathrm{L} \mathrm{Cl}_{2}$ added \\
\hline 11.6 & 7.29 & 0.421 & 0.00 \\
11.4 & 7.3 & 0.427 & 0.01 \\
11.0 & 7.29 & 0.442 & 0.03 \\
9.2 & 7.31 & 0.463 & 0.04 \\
8.9 & 7.32 & 0.480 & 0.06 \\
8.5 & 7.33 & 0.502 & 0.08 \\
8.5 & 7.31 & 0.524 & 0.12 \\
8.6 & 7.32 & 0.547 & 0.16 \\
9.0 & 7.34 & 0.566 & 0.20 \\
9.5 & 7.36 & 0.576 & 0.25 \\
9.8 & 7.37 & 0.582 & 0.30 \\
9.7 & 7.38 & 0.595 & 0.43 \\
9.6 & 7.39 & 0.614 & 0.63 \\
9.6 & 7.39 & 0.614 & 0.63 \\
9.4 & 7.41 & 0.621 & 0.94 \\
9.5 & 7.42 & 0.631 & 1.57 \\
9.6 & 7.42 & 0.644 & 2.19 \\
9.7 & 7.43 & 0.661 & 7.21 \\
9.9 & 7.44 & 0.672 & 12.85 \\
\hline
\end{tabular}


Table A.40 ORP Titration of RO at 25C using Chloramine

\begin{tabular}{cccc}
\hline Temperature ${ }^{\circ} \mathrm{C}$ & $\mathrm{pH}$ & Volts $(\mathrm{SHE})$ & $\mathrm{mg} / \mathrm{L} \mathrm{Cl}_{2}$ added \\
\hline 23.9 & 7.62 & 0.523 & 0.00 \\
24.4 & 7.62 & 0.524 & 0.03 \\
24.5 & 7.64 & 0.527 & 0.04 \\
24.6 & 7.65 & 0.530 & 0.05 \\
24.6 & 7.65 & 0.533 & 0.06 \\
24.6 & 7.64 & 0.536 & 0.08 \\
24.6 & 7.67 & 0.540 & 0.09 \\
24.6 & 7.66 & 0.543 & 0.10 \\
24.6 & 7.66 & 0.546 & 0.12 \\
24.5 & 7.65 & 0.551 & 0.13 \\
24.5 & 7.66 & 0.555 & 0.14 \\
24.5 & 7.67 & 0.560 & 0.16 \\
24.4 & 7.68 & 0.564 & 0.17 \\
24.4 & 7.68 & 0.567 & 0.19 \\
24.4 & 7.69 & 0.570 & 0.21 \\
24.3 & 7.69 & 0.573 & 0.22 \\
24.3 & 7.68 & 0.576 & 0.23 \\
24.3 & 7.69 & 0.579 & 0.25 \\
24.3 & 7.70 & 0.581 & 0.27 \\
24.2 & 7.73 & 0.583 & 0.28 \\
24.2 & 7.71 & 0.586 & 0.31 \\
24.1 & 7.72 & 0.590 & 0.34 \\
24.1 & 7.72 & 0.592 & 0.36 \\
24.1 & 7.73 & 0.595 & 0.40 \\
24.0 & 7.73 & 0.598 & 0.44 \\
24.0 & 7.75 & 0.604 & 0.50 \\
23.7 & 7.73 & 0.620 & 0.50 \\
23.7 & 7.73 & 0.620 & 0.84 \\
23.8 & 7.72 & 0.626 & 1.17 \\
23.8 & 7.74 & 0.634 & 1.84 \\
23.8 & 7.72 & 0.644 & 3.17 \\
23.8 & 7.72 & 0.651 & 4.84 \\
23.8 & 7.73 & 0.658 & 6.50 \\
23.8 & 7.74 & 0.663 & 8.50 \\
23.7 & 7.75 & 0.668 & 10.50 \\
23.7 & 7.76 & 0.670 & 11.17 \\
\hline
\end{tabular}


Table A.41 ORP Titration of RO at 30C using Chloramine

\begin{tabular}{cccc}
\hline Temperature ${ }^{\circ} \mathrm{C}$ & $\mathrm{pH}$ & Volts $(\mathrm{SHE})$ & $\mathrm{mg} / \mathrm{L} \mathrm{Cl}_{2}$ added \\
\hline 30.0 & 7.45 & 0.486 & 0.00 \\
29.9 & 7.51 & 0.493 & 0.01 \\
29.8 & 7.50 & 0.502 & 0.03 \\
29.9 & 7.55 & 0.523 & 0.06 \\
29.8 & 7.56 & 0.535 & 0.08 \\
29.6 & 7.58 & 0.546 & 0.11 \\
29.7 & 7.60 & 0.555 & 0.15 \\
30.8 & 7.61 & 0.563 & 0.19 \\
31.6 & 7.62 & 0.571 & 0.25 \\
31.7 & 7.62 & 0.577 & 0.28 \\
31.6 & 7.62 & 0.588 & 0.34 \\
31.5 & 7.62 & 0.593 & 0.38 \\
31.0 & 7.63 & 0.598 & 0.42 \\
31.2 & 7.63 & 0.606 & 0.49 \\
31.0 & 7.63 & 0.611 & 0.53 \\
30.5 & 7.64 & 0.617 & 0.60 \\
30.5 & 7.64 & 0.617 & 0.60 \\
30.2 & 7.64 & 0.626 & 1.55 \\
30.1 & 7.65 & 0.634 & 2.19 \\
29.6 & 7.65 & 0.639 & 4.41 \\
29.5 & 7.66 & 0.642 & 5.68 \\
29.5 & 7.66 & 0.645 & 6.95 \\
29.4 & 7.67 & 0.648 & 11.72 \\
\hline
\end{tabular}


Table A.42 ORP Titration of RO at $25 \mathrm{C}$ using Free Chlorine with $35.5 \mathrm{mg} / \mathrm{L} \mathrm{Cl}^{-}$

\begin{tabular}{cccc}
\hline Temperature ${ }^{\circ} \mathrm{C}$ & $\mathrm{pH}$ & Volts $(\mathrm{SHE})$ & $\mathrm{mg} / \mathrm{L} \mathrm{Cl}_{2}$ added \\
\hline 19.9 & 7.50 & 0.680 & 0.00 \\
20.0 & 7.53 & 0.679 & 0.01 \\
20.0 & 7.55 & 0.683 & 0.03 \\
20.0 & 7.56 & 0.690 & 0.04 \\
20.1 & 7.56 & 0.701 & 0.05 \\
20.1 & 7.59 & 0.716 & 0.07 \\
20.2 & 7.61 & 0.736 & 0.08 \\
20.3 & 7.62 & 0.759 & 0.09 \\
20.3 & 7.63 & 0.777 & 0.11 \\
20.4 & 7.65 & 0.798 & 0.13 \\
20.5 & 7.66 & 0.814 & 0.15 \\
20.6 & 7.68 & 0.836 & 0.20 \\
20.6 & 7.69 & 0.855 & 0.25 \\
20.7 & 7.70 & 0.872 & 0.31 \\
20.7 & 7.71 & 0.881 & 0.37 \\
20.8 & 7.72 & 0.888 & 0.44 \\
20.8 & 7.72 & 0.894 & 0.52 \\
20.8 & 7.72 & 0.894 & 0.52 \\
20.8 & 7.74 & 0.907 & 0.85 \\
20.9 & 7.77 & 0.918 & 1.52 \\
20.9 & 7.81 & 0.928 & 2.52 \\
20.9 & 7.83 & 0.936 & 3.85 \\
20.9 & 7.88 & 0.943 & 5.85 \\
21.0 & 7.91 & 0.950 & 8.52 \\
21.0 & 7.94 & 0.955 & 10.52 \\
\hline
\end{tabular}


Table A.43 ORP Titration of RO at $25 \mathrm{C}$ using Free Chlorine $71 \mathrm{mg} / \mathrm{L} \mathrm{Cl}^{-}$

\begin{tabular}{cccc}
\hline Temperature ${ }^{\circ} \mathrm{C}$ & $\mathrm{pH}$ & Volts $(\mathrm{SHE})$ & $\mathrm{mg} / \mathrm{L} \mathrm{Cl}_{2}$ added \\
\hline 19.4 & 7.39 & 0.672 & 0.00 \\
19.4 & 7.40 & 0.669 & 0.01 \\
19.4 & 7.41 & 0.671 & 0.02 \\
19.5 & 7.42 & 0.674 & 0.04 \\
19.5 & 7.43 & 0.679 & 0.05 \\
19.6 & 7.45 & 0.686 & 0.06 \\
19.6 & 7.46 & 0.701 & 0.08 \\
19.7 & 7.48 & 0.718 & 0.10 \\
19.8 & 7.49 & 0.740 & 0.12 \\
19.9 & 7.52 & 0.767 & 0.15 \\
19.9 & 7.53 & 0.787 & 0.18 \\
20.0 & 7.54 & 0.800 & 0.21 \\
20.0 & 7.55 & 0.812 & 0.24 \\
20.1 & 7.56 & 0.820 & 0.27 \\
20.2 & 7.58 & 0.829 & 0.30 \\
20.2 & 7.59 & 0.837 & 0.34 \\
20.2 & 7.59 & 0.846 & 0.38 \\
20.3 & 7.60 & 0.857 & 0.43 \\
20.3 & 7.61 & 0.862 & 0.48 \\
20.4 & 7.62 & 0.868 & 0.54 \\
20.4 & 7.62 & 0.868 & 0.54 \\
20.4 & 7.64 & 0.886 & 0.87 \\
20.4 & 7.66 & 0.897 & 1.21 \\
20.5 & 7.68 & 0.904 & 1.54 \\
20.5 & 7.71 & 0.911 & 2.21 \\
20.5 & 7.73 & 0.918 & 3.21 \\
20.6 & 7.77 & 0.928 & 4.54 \\
20.6 & 7.81 & 0.935 & 6.54 \\
20.6 & 7.85 & 0.940 & 8.54 \\
20.6 & 7.88 & 0.945 & 11.87 \\
20.7 & 7.92 & 0.950 & 15.21 \\
20.7 & 7.94 & 0.955 & 18.54 \\
\hline & & &
\end{tabular}


Table A.44 ORP Titration of RO at $25 \mathrm{C}$ using Free Chlorine $106.5 \mathrm{mg} / \mathrm{L} \mathrm{Cl}^{-}$

\begin{tabular}{cccc}
\hline Temperature ${ }^{\circ} \mathrm{C}$ & $\mathrm{pH}$ & Volts $(\mathrm{SHE})$ & $\mathrm{mg} / \mathrm{L} \mathrm{Cl}_{2}$ added \\
\hline 20.0 & 7.48 & 0.491 & 0.00 \\
20.1 & 7.52 & 0.527 & 0.02 \\
20.1 & 7.53 & 0.562 & 0.04 \\
20.1 & 7.54 & 0.589 & 0.05 \\
20.1 & 7.54 & 0.611 & 0.06 \\
20.2 & 7.55 & 0.645 & 0.08 \\
20.2 & 7.56 & 0.674 & 0.10 \\
20.2 & 7.56 & 0.699 & 0.12 \\
20.3 & 7.57 & 0.717 & 0.14 \\
20.3 & 7.58 & 0.732 & 0.17 \\
20.3 & 7.58 & 0.753 & 0.20 \\
20.4 & 7.59 & 0.766 & 0.22 \\
20.4 & 7.60 & 0.786 & 0.26 \\
20.4 & 7.61 & 0.805 & 0.29 \\
20.5 & 7.63 & 0.813 & 0.32 \\
20.6 & 7.64 & 0.823 & 0.36 \\
20.6 & 7.64 & 0.832 & 0.40 \\
20.6 & 7.65 & 0.840 & 0.43 \\
20.6 & 7.66 & 0.848 & 0.52 \\
20.7 & 7.67 & 0.853 & 0.59 \\
20.7 & 7.67 & 0.853 & 0.59 \\
20.7 & 7.69 & 0.867 & 0.92 \\
20.7 & 7.71 & 0.876 & 1.25 \\
20.7 & 7.74 & 0.887 & 1.92 \\
20.7 & 7.77 & 0.897 & 3.25 \\
20.7 & 7.80 & 0.902 & 4.25 \\
20.8 & 7.82 & 0.908 & 5.25 \\
20.8 & 7.85 & 0.913 & 6.59 \\
20.8 & 7.87 & 0.917 & 8.25 \\
20.8 & 7.89 & 0.922 & 10.25 \\
\hline & & &
\end{tabular}


Table A.45 ORP Titration of RO at $25 \mathrm{C}$ using Chloramine $35.5 \mathrm{mg} / \mathrm{L} \mathrm{Cl}^{-}$

\begin{tabular}{cccc}
\hline Temperature ${ }^{\circ} \mathrm{C}$ & $\mathrm{pH}$ & Volts $(\mathrm{SHE})$ & $\mathrm{mg} / \mathrm{L} \mathrm{Cl}_{2}$ added \\
\hline 22.5 & 7.84 & 0.588 & 0.00 \\
22.5 & 7.85 & 0.586 & 0.02 \\
22.5 & 7.85 & 0.586 & 0.03 \\
22.6 & 7.86 & 0.586 & 0.06 \\
22.6 & 7.87 & 0.587 & 0.09 \\
22.6 & 7.87 & 0.588 & 0.11 \\
22.6 & 7.88 & 0.590 & 0.15 \\
22.6 & 7.88 & 0.595 & 0.19 \\
22.7 & 7.88 & 0.598 & 0.23 \\
22.7 & 7.89 & 0.603 & 0.27 \\
22.7 & 7.89 & 0.607 & 0.31 \\
22.7 & 7.90 & 0.613 & 0.35 \\
22.7 & 7.91 & 0.617 & 0.39 \\
22.7 & 7.91 & 0.617 & 0.39 \\
22.8 & 7.91 & 0.636 & 0.72 \\
22.8 & 7.92 & 0.642 & 1.05 \\
22.8 & 7.92 & 0.656 & 1.38 \\
22.8 & 7.92 & 0.668 & 2.04 \\
22.8 & 7.91 & 0.678 & 3.03 \\
22.9 & 7.90 & 0.688 & 4.34 \\
22.9 & 7.90 & 0.694 & 5.66 \\
22.9 & 7.87 & 0.700 & 7.63 \\
22.9 & 7.85 & 0.704 & 9.61 \\
22.9 & 7.85 & 0.707 & 10.92 \\
23.0 & 7.84 & 0.709 & 12.24 \\
\hline
\end{tabular}


Table A.46 ORP Titration of RO at $25 \mathrm{C}$ using Chloramine $71 \mathrm{mg} / \mathrm{L} \mathrm{Cl}^{-}$

\begin{tabular}{cccc}
\hline Temperature ${ }^{\circ} \mathrm{C}$ & $\mathrm{pH}$ & Volts $(\mathrm{SHE})$ & $\mathrm{mg} / \mathrm{L} \mathrm{Cl}_{2}$ added \\
\hline 22.0 & 7.78 & 0.580 & 0.00 \\
22.2 & 7.86 & 0.578 & 0.01 \\
22.2 & 7.86 & 0.577 & 0.01 \\
22.3 & 7.87 & 0.576 & 0.03 \\
22.3 & 7.87 & 0.576 & 0.04 \\
22.4 & 7.87 & 0.577 & 0.05 \\
22.4 & 7.88 & 0.578 & 0.07 \\
22.4 & 7.88 & 0.580 & 0.09 \\
22.4 & 7.89 & 0.582 & 0.12 \\
22.5 & 7.89 & 0.585 & 0.16 \\
22.5 & 7.89 & 0.589 & 0.20 \\
22.5 & 7.89 & 0.592 & 0.24 \\
22.5 & 7.90 & 0.599 & 0.29 \\
22.6 & 7.90 & 0.603 & 0.35 \\
22.6 & 7.90 & 0.613 & 0.41 \\
22.6 & 7.90 & 0.613 & 0.41 \\
22.7 & 7.91 & 0.630 & 0.74 \\
22.7 & 7.91 & 0.647 & 1.07 \\
22.8 & 7.91 & 0.654 & 1.40 \\
22.8 & 7.92 & 0.664 & 1.73 \\
22.9 & 7.91 & 0.674 & 2.39 \\
22.9 & 7.90 & 0.680 & 3.05 \\
23.0 & 7.89 & 0.686 & 4.36 \\
23.0 & 7.88 & 0.692 & 5.68 \\
23.0 & 7.86 & 0.697 & 7.65 \\
23.0 & 7.83 & 0.704 & 10.28 \\
23.0 & 7.81 & 0.708 & 12.92 \\
23.0 & 7.79 & 0.711 & 15.55 \\
\hline & & &
\end{tabular}


Table A.47 ORP Titration of RO at $25 \mathrm{C}$ using Chloramine $106.5 \mathrm{mg} / \mathrm{L} \mathrm{Cl}^{-}$

\begin{tabular}{cccc}
\hline Temperature ${ }^{\circ} \mathrm{C}$ & $\mathrm{pH}$ & Volts $(\mathrm{SHE})$ & $\mathrm{mg} / \mathrm{L} \mathrm{Cl}_{2}$ added \\
\hline 21.8 & 7.78 & 0.543 & 0.00 \\
21.9 & 7.79 & 0.542 & 0.01 \\
22.0 & 7.81 & 0.543 & 0.03 \\
22.0 & 7.81 & 0.549 & 0.06 \\
22.1 & 7.84 & 0.557 & 0.08 \\
22.2 & 7.84 & 0.568 & 0.12 \\
22.2 & 7.85 & 0.574 & 0.16 \\
22.3 & 7.85 & 0.578 & 0.19 \\
22.3 & 7.86 & 0.586 & 0.23 \\
22.4 & 7.87 & 0.592 & 0.28 \\
22.4 & 7.87 & 0.597 & 0.33 \\
22.5 & 7.87 & 0.604 & 0.39 \\
22.6 & 7.87 & 0.604 & 0.39 \\
22.6 & 7.88 & 0.622 & 0.72 \\
22.7 & 7.88 & 0.632 & 1.04 \\
22.7 & 7.88 & 0.640 & 1.37 \\
22.8 & 7.88 & 0.657 & 2.03 \\
22.8 & 7.88 & 0.666 & 2.69 \\
22.8 & 7.87 & 0.674 & 3.68 \\
22.9 & 7.86 & 0.682 & 4.99 \\
22.9 & 7.84 & 0.690 & 6.97 \\
22.9 & 7.83 & 0.694 & 8.28 \\
23.0 & 7.82 & 0.697 & 9.60 \\
23.0 & 7.81 & 0.699 & 11.24 \\
\hline
\end{tabular}

